NBER WORKING PAPER SERIES

\title{
AUTONOMY AND SPECIFICITY IN \\ AGRICULTURAL TECHNOLOGY ADOPTION: \\ EVIDENCE FROM MEXICO
}

Carolina Corral

Xavier Giné

Aprajit Mahajan

Enrique Seira

Working Paper 27681

http://www.nber.org/papers/w27681

\author{
NATIONAL BUREAU OF ECONOMIC RESEARCH \\ 1050 Massachusetts Avenue \\ Cambridge, MA 02138 \\ August 2020
}

We are grateful to Qué Funciona para el Desarrollo (QFD) for managing the entire project, to Fertilab for the soil analyses, to Agropecuaria Amozoc for providing and mixing fertilizers and to Ipampa S.C. for the provision of agricultural extension services. We would also like to thank Pranab Bardhan, Chico Ferreira, Andy Foster, and Berk Özler for very helpful comments and suggestions. We also thank seminar participants at various workshops for their comments and suggestions. Michelle Infanzón, Victor Manuel Pérez, Bernardo Ribeiro, Mónica Vargas and Victor Vergara provided outstanding research assistance. We also gratefully acknowledge funding from 3ie, BASIS (UC Davis), the World Bank and ISPC-SPIA (under the grant "Strengthening Impact Assessment in the CGIAR System (SIAC)"). Views expressed in this paper are those of the authors, and do not necessarily reflect the opinions of the World Bank, its executive directors, or the countries they represent. This project was reviewed and approved by the ITAM IRB and UCLA IRB \# 12-001756. This study is registered in the AEA RCT Registry with the unique identifying number AEARCTR-0006264. The views expressed herein are those of the authors and do not necessarily reflect the views of the National Bureau of Economic Research.

NBER working papers are circulated for discussion and comment purposes. They have not been peer-reviewed or been subject to the review by the NBER Board of Directors that accompanies official NBER publications.

(C) 2020 by Carolina Corral, Xavier Giné, Aprajit Mahajan, and Enrique Seira. All rights reserved. Short sections of text, not to exceed two paragraphs, may be quoted without explicit permission provided that full credit, including $\odot$ notice, is given to the source. 
Autonomy and Specificity in Agricultural Technology Adoption: Evidence from Mexico

Carolina Corral, Xavier Giné, Aprajit Mahajan, and Enrique Seira

NBER Working Paper No. 27681

August 2020

JEL No. D01,O33,Q12

\begin{abstract}
$\underline{\text { ABSTRACT }}$
We explore heterogeneity in soil quality, lack of knowledge and autonomy as explanations for the low adoption of improved agricultural practices using a randomized field experiment that combined localized soil analyses, tailored input recommendations, extension services and an inkind grant. We find that while neither the degree of recommendation specificity (plot vs cluster level) nor the extent of autonomy (defined as the freedom of choice in spending the in-kind grant) had any effect on adoption during the intervention, farmers with autonomy had substantially higher adoption of improved practices two years after the intervention ended.
\end{abstract}

$\begin{array}{ll}\text { Carolina Corral } & \text { Aprajit Mahajan } \\ \text { Social Impact, Inc. } & \begin{array}{l}\text { Dept. of Agricultural \& Resource Economics } \\ \text { Jerez } 19 \text { int 6, Benito Juarez } \\ \text { Mexico }\end{array} \\ \text { carocorral@gmail.com } & \begin{array}{l}\text { 219 Giannini Hall } \\ \text { Berkeley, CA 94720-3310 } \\ \text { and NBER }\end{array} \\ \text { Xavier Giné } & \text { aprajit@gmail.com } \\ \text { The World Bank } & \text { Enrique Seira } \\ \text { 1818 H Street N.W. } & \text { Centro de Investigación Económica } \\ \text { Mail Stop MC 3-307 } & \text { ITAM } \\ \text { Washington, D.C. 20433 } & \text { Ave. Santa Teresa \# 930 } \\ \text { xgine@ worldbank.org } & \text { Mexico } \\ & \text { enrique.seira@ gmail.com }\end{array}$

A randomized controlled trials registry entry is available at AEARCTR-0006264 


\section{Introduction}

Policies that increase agricultural productivity arguably have a disproportionate effect on poverty reduction (World Bank, 2008). The Green Revolution introduced high-yielding crop varieties, chemical fertilizer, pesticides and other modern agricultural practices to developing countries. However, even decades after their introduction, the take up of these improved inputs and practices has been uneven (Foster and Rosenzweig, 2010). Traditional farming practices remain widespread and yields for smallholder farmers in the developing world remain low. ${ }^{1}$

A variety of explanations have been proposed for the observed low rates of technology adoption in the developing world, including limited information on best practices, credit constraints, risk, poor input quality, and behavioral biases. ${ }^{2}$ An alternative view is that heterogeneity in returns reflects heterogeneity in a fixed factor (or infrastructure) thus explaining the observed variation in adoption rates (e.g. Suri, 2011).

In this paper we test several hypotheses on the role of information while explicitly recognizing the importance of heterogeneity in soil quality. ${ }^{3}$ We test our hypotheses in an accretive manner: first, using our sample of small rainfed farms in Tlaxcala, Mexico, we confirm that heterogeneity in soil quality leads to heterogeneity in the recommended mix of fertilizers. Next, we test whether farmers adopt these tailored recommendations (based on the soil analyses) and whether productivity improves as a result. We then test whether the level of information specificity, that is, whether recommendations are based on the farmer's own plot or on a larger geographical cluster, matters for adoption and persistence of improved agricultural practices. This is important because evidence suggests that while individually tailored information may be more more effective, they are also more expensive than recommendations based on aggregated information, thus introducing a trade-off. ${ }^{4}$

We also offer farmers one of two types of in-kind grant to purchase inputs: inflexible (i.e. subsidizing only the recommended inputs) or flexible (i.e. giving farmers the choice of which inputs to purchase). The difference between the two grants allows us to examine the effect of autonomy, defined here as the ability to choose the inputs purchased with the grant. While the broader notion of autonomy and its intrinsic value has received some attention in the literature,

\footnotetext{
${ }^{1}$ In Mexico for instance, maize yields for rainfed farmers are only about $2-3$ metric tons per hectare (mt/ha). By comparison, rainfed maize yields in the United States are approximately $8 \mathrm{mt} /$ ha (Sweeney et al. 2013; Fernández et al. 2012).

${ }^{2}$ On information, see Conley and Udry (2010); Ashraf et al. (2009); on liquidity and credit see e.g. Karlan et al. (2014); on risk see Karlan et al. (2014); Emerick et al. (2016); Giné et al. (2017); on behavioral biases see Duflo et al. (2011); on input quality see Bold et al. (2017). For a recent overview of the evidence see e.g. Magruder (2018) and Macours (2019).

${ }^{3}$ See Jayne and Rashid, 2013; Goyal and Nash, 2017. Munshi (2004) and Otsuka and Larson (2013), for example, argue that unobserved farm characteristics such as soil quality are important for technology adoption.

${ }^{4}$ See e.g. Madajewicz et al. (2007) on the efficacy of providing localized information in the context of arsenic poisoning in Bangladesh.
} 
we focus here on its potential for increasing adherence to the recommendations both during and after the intervention. ${ }^{5}$

The experiment consists of a control group and four treatment arms that combine soil analysis and recommendations (either at the plot or cluster level) with flexible or inflexible in-kind grants. ${ }^{6}$ Due to budgetary constraints, we did not implement a full factorial design. Rather, farmers in all treatment arms were offered a soil analysis report, a set of input recommendations and a package of agricultural extension services designed to help them implement the recommendations. In addition, three of the four treatment arms were offered an in-kind grant of 2,000 pesos (roughly $\$ 150$ at the time of the intervention).

In particular, arm $T 1$ received individualized or plot level soil analyses with input recommendations and an inflexible in-kind grant. Arm T2 was the same as T1 except that the soil analysis and recommendations were averaged (so that recommendations were identical for all farmers in the cluster). Comparing $T 1$ with $T 2$ allows us to estimate the effect of varying the level of the specificity of the soil analysis and recommendations (conditional on receipt of an inflexible grant). Arm T3 differed from T2 in that the in-kind grant was flexible and so farmers in T3 could use the in-kind grant to purchase any inputs of their choosing sold by a local agro-dealer rather than just the recommended ones. A comparison between $T 2$ and $T 3$ thus measures the effect of autonomy as defined above. The conditions for arm $T 4$ are the same as those for $T 2$ (or T3) except that no grant was provided. Comparisons between T4 and T2 (or T3) measure the effect of providing the in-kind grant (conditional on receipt of localized information and recommendations). Finally, a control group of farmers $C$ did not receive any interventions during the experiment, but instead received soil analyses and recommendations - but no extension services - the year after the intervention ended. Comparisons between $C$ and T4 estimate the effect of providing localized soil analyses, recommendations and extension services. In later years, after the intervention had ended and control farmers had also received soil analyses and recommendations, comparing $C$ and $T 4$ provides an estimate of the effect of agricultural extension services paired with tailored analyses and recommendations (but with that qualification that the control group received the soil analysis and recommendations one year after T4).

We first document substantial heterogeneity in soil quality, mostly within (rather than between) clusters. ${ }^{7}$ This heterogeneity implies a corresponding variation in the optimal mix of fertilizers. While most farmers used chemical fertilizer prior to the intervention, their input mix was substantially different from the recommended mix: farmers used on average $77 \%$

\footnotetext{
${ }^{5}$ On the intrinsic importance of autonomy see e.g. Sen (1999); Bartling et al. (2014); Ferreira et al. (2020). We discuss the instrumental value of autonomy further below.

${ }^{6}$ A cluster corresponds to a neighboring INEGI localidad. See footnote 16 in Section 2 for more details. In Mexico there are almost 2,500 municipalities and close to 200,000 INEGI localidades.

${ }^{7}$ Under standard ANOVA assumptions, the "between" cluster component of the total variation is $41 \%$ for sand, $31 \%$ for Clay, $38 \%$ for Silt, $11 \%$ for Nitrogen, $21 \%$ for Phosphorus, $20 \%$ for Potassium and 36\% for the soil $\mathrm{pH}$ level. See Appendix Table A1 for details.
} 
more urea than the recommended amount and about $61 \%$ more diammonium phosphate (DAP) while using only about $28 \%$ of the recommended amount of Potassium Chloride $(\mathrm{KCl})$.

We next examine adoption, our main outcome of interest, using a standardized index of "new" agricultural practices introduced by the intervention. ${ }^{8}$ By this metric, farmers who only received the recommendations and extension services (T4) adopted 0.33 more practices (measured in standard deviations or s.d.) relative to control farmers (who have an adoption index of zero, by construction). Farmers that received the in-kind grant adopted considerably more practices (ranging from 1.68 to 1.96 s.d. depending on the arm) underscoring the importance of the in-kind grant. Since its value was designed to be roughly equal to the amount spent on fertilizer by control farmers, we view the grant as primarily encouraging experimentation rather than relaxing liquidity constraints. ${ }^{9}$ Surprisingly, 73 farmers, who had the option to entirely ignore the recommendations at no cost, adopted these new practices at the same rate as $T 2$ farmers who were forced to either adopt the recommendations or forego the grant. Finally, contrary to the work cited above, we find no evidence in favor of specificity since $T 1$ farmers did not increase adoption of new practices relative to farmers in $T 2 .{ }^{10}$

We also examine the impact of the treatments on productivity and perhaps unsurprisingly find results similar to those on adoption. Average yields and profits for farmers that only received the soil analysis, recommendations and extension services (in T4) are not statistically different from those in the control group. In contrast, and similar to the impact on adoption, we find substantial effects of providing the in-kind grant. Despite a drought, yields for farmers that received a grant were $0.2-0.4 \mathrm{mt} /$ ha higher relative to those for control farmers, corresponding to an increase of approximately $12-17 \%$. The increase in profits is more muted and not statistically significant at conventional levels. We also find that neither specificity nor autonomy affected yields or profits. In the short run then (i.e. during the intervention) there appears to be no significant downside to providing farmers with autonomy.

Finally, we examine the persistence of the recommended practices in the 2017 growing season (the second growing season after the intervention ended). Farmers who had only received

\footnotetext{
${ }^{8}$ We classify six practices as "new" since they were uncommon at baseline and recommended by the extension workers. Details of the index construction are in Table 6 and Appendix Table A3. See Bloom et al. (2013) for a similar classification of practices in the context of a management intervention.

${ }^{9}$ The grant could also be viewed as an implicit endorsement of the recommendations or as a means for the research team to differentiate itself from cheap talk. We do not attempt to distinguish between these alternative explanations.

${ }^{10}$ As we discuss in greater detail below, $T 1$ farmers had somewhat lower adoption rates than $T 2$ farmers. Confounding the comparison, however, is the fact that plot-level recommendations were on average more expensive and thus required a larger out-of-pocket expense than cluster level ones. To see why this might be the case, consider a cluster with 2 farmers (A and B) with a plot of 1 ha each. The plot of Farmer A has a deficit of nutrient P of $20 \mathrm{Kg}$ while the plot of Farmer B has an excess of nutrient $\mathrm{P}$ of $20 \mathrm{Kg}$. The average of plot-level recommendations for nutrient $\mathrm{P}$ will be $10 \mathrm{Kg}$. However the average of the cluster level recommendation for $\mathrm{P}$ will be $0 \mathrm{Kg}$, because the excess of the nutrient in the plot of Farmer B compensates the deficit in the plot of Farmer A and thus there is no overall deficit in the cluster.
} 
the recommendations and extension services in 2015 adopted 0.39 s.d. more practices in 2017 relative to control farmers. Since control farmers received recommendations at the start of the 2016 growing season, this difference reflects the effect of the one-time provision of extension services paired with recommendations (in 2015) relative to receiving just the recommendations (in 2016). We view this as strong suggestive evidence of the complementarities between extension services and recommendations, consistent with work in other contexts. ${ }^{11}$ This result contributes to the relatively recent literature attempting to credibly identify the effect of agricultural extension services. ${ }^{12}$

More interestingly, farmers who had received the flexible in-kind grant, and thus had autonomy to choose which recommendations to follow in 2015, were substantially more likely to persist with the new practices in 2017 relative to farmers with the inflexible in-kind grant (an increase of 0.55 s.d.) and to farmers in the control group (an increase of 1.08 s.d.). The fact that some farmers continued to use the new practices two years after the intervention suggests that they were perceived as valuable (despite the lack of impacts on our measure of profits). This result suggests that it may be desirable to provide beneficiaries of a program with a measure of autonomy, particularly if the program is top-down and involves expert advice. We next explore various mechanisms behind the result. Consistent with the hypothesis that autonomy induced farmers to pay more attention to the recommendations, we find that farmers with autonomy in $T 3$ were more likely to remember the recommendations, to repose the most trust in project partners and to have a more positive attitude towards experimentation.

Our results contribute most directly to the recent literature on the impact of tailored input recommendations on farmer behavior. Fishman et al. (2016) evaluate a large-scale program that provided plot-level soil analyses and fertilizer recommendations to farmers in Bihar (India). While they find substantial heterogeneity in soil quality, there was no effect of the recommendations on actual fertilizer use. The authors speculate that this could be because farmers did not understand the information, lacked confidence in its reliability or that the recommended fertilizer mixes were too expensive. In our study, we spent a substantial amount of time and resources facilitating farmer comprehension of the soil analyses and recommendations and use a well-known and trusted agricultural extension services firm to convey the information. ${ }^{13}$

Murphy et al. (2019) find that providing plot-level soil information to farmers in Western

${ }_{11}$ For example, in an experiment providing management consulting to large firms in India, Bloom et al. (2013) find that merely providing recommendations (as they did to the control firms) had relatively limited effects compared to pairing the recommendations with consultants that helped firms in implementing the recommendations.

${ }^{12}$ See Beaman et al. (2018); Kondylis et al. (2017) on learning in the contact farmer extension model and Cole and Fernando (2020) on the effectiveness of mobile-phone based extension services in India. See Magruder (2018) for a summary of the past decade of work on the effectiveness of extension services in developing country contexts (see e.g Anderson and Feder, 2007, for a review of older work).

${ }^{13}$ Tjernström (2017) also documents soil quality heterogeneity in a sample of Kenyan farms and examines the difficulties it creates for social learning about new technologies. 
Kenya (using SoilDoc, a low-cost soil testing tool) has a positive effect on the willingness to pay for inputs (DAP and manure, among others) but do not measure longer-term fertilizer use or productivity. Our work is perhaps closest to Harou et al. (2018) who offer soil analyses, fertilizer recommendations (using SoilDoc) and an in-kind grant that covers the cost of fertilizer for approximately 0.2 ha. ${ }^{14}$ We complement their work by measuring the impact of recommendation specificity, assessing the effect of autonomy and examining both shorter-run outcomes as well as longer-term persistence.

We also contribute to the literature on mis-allocation (see e.g. Restuccia and Rogerson, 2017, for a survey) by providing micro-evidence on the inefficient use of fertilizer in agricultural production. In our context, since farmers were already familiar with inorganic fertilizer, our intervention recommended changes in the intensive margin (i.e. input mix), rather than the extensive margin, at no extra cost because the value of the recommendations was similar to the average amount that farmers spent on fertilizer. We believe that documenting such misallocation of fertilizer is important both from the perspective of the individual farmer who could improve productivity by reallocating inputs, as well as that of the social planner since the over-use of urea and the consequent nitrogen leaching and surface run-off could have significant negative environmental consequences (see e.g. Wang and Li, 2019, for a review of the evidence).

Our results also contribute to the debate about the appropriate level of specificity when testing soil quality and providing input recommendations. Harou et al. (2018); Duflo et al. (2011); Marenya and Barrett (2009); Sheahan et al. (2013) all find that official recommendations are too generic (typically at a state or country level) to account for local soil heterogeneity. Smallholder farmers in the developing world typically fertilize using average recommendations, with no information on which elements are most needed, and primarily use urea and DAP. Ours appears to be the first paper to compare plot to cluster level recommendations using field experimental evidence.

Finally, we contribute to the literature on autonomy, which has emphasized both its intrinsic as well as its instrumental value on participatory decision-making (broadly construed), compliance (Malesky and Taussig, 2019; Dal Bó et al., 2010), effort (Sjöström et al., 2018) and productivity (e.g. Black and Lynch, 2001; Bonin et al., 1993; Spector, 1986). Using observational data from an agricultural context, Bardhan (2000) finds that Indian farmers are less likely to violate irrigation rules when they themselves have crafted those rules. The reactance literature in psychology (Wicklund, 1974; Fitzsimons and Lehmann, 2004) argues that recommendations by experts may backfire as agents purposefully try to contradict them. We show that providing autonomy in the decision to follow expert advice may in fact lead to higher adherence in the

\footnotetext{
${ }^{14}$ They study Tanzania, where fertilizer usage is low (less than one percent of study farmers had used fertilizer at baseline) and thus the recommendations suggest substantial increases in input use.
} 
longer-term. From a policy perspective, understanding whether and how autonomy encourages the use of agricultural best practices is important as policy makers re-design agricultural input subsidy and extension programs ubiquitous in developing countries. From an academic perspective, we contribute to the debate by documenting the importance of autonomy for technology adoption and providing some evidence on the possible mechanisms at play, although more research is needed. ${ }^{15}$

The rest of the paper is organized as follows. Section 2 describes the context and data used while section 3 provides the details of the design and rationale for the various experimental arms. Section 4 describes the empirical strategy and sections 5 and 6 present the short and long term results, respectively. Section 7 concludes.

\section{Context}

This project was a collaborative effort between three organizations: our partner NGO "Qué Funciona para el Desarrollo" or QFD; Ipampa S.C., a long-standing local private extension service company, and Agropecuaria Amozoc, a commercial fertilizer dealer. The project was implemented in 13 municipalities of the Mexican state of Tlaxcala, chosen for having substantial rainfed smallholder farmer populations (see Figure 1) with relatively low maize yields (2.7 tons per hectare on average).

In January 2015, QFD advertised the program widely by displaying posters prominently in public locations and handing out informational leaflets. QFD also organized a total of 34 promotional meetings in the principal towns in each municipality. The promotional meetings lasted between 60-90 minutes and typically took place in a large public space (e.g. a municipal auditorium). During the meetings, the research team introduced and explained the intervention, described the eligibility requirements, and the lottery design. A total of 1,299 farmers that attended the promotional meetings and potentially interested farmers were asked to complete a short form.

Between February and March 2015, interested farmers were visited by the research team. During the visit, the team collected a detailed baseline survey on a range of farmer characteristics and agricultural practices during the previous growing season (2014). After the survey, farmers were asked to register a subplot of one hectare for the program where they planned to grow maize. QFD cordoned off this subplot, GPS coordinates for the subplot were recorded,

\footnotetext{
${ }^{15}$ The literature on the impacts of cash transfer programs is also related (see Benhassine et al., 2015; Baird et al., 2019, and see Molina-Millán et al., 2019 for a review). This literature has examined the difference between unconditional and conditional transfers both in the short- and longer-terms focusing particularly on human capital, consumption, and well-being. In a conditional cash transfer program beneficiaries can use the transfer amount as they please, but the cash is received only if the beneficiary complies with the conditions (Fiszbein and Schady, 2009). In contrast, we provide in-kind grants that directly subsidize (or not) the desired activity.
} 
and soil samples were collected.

Table 1 presents the timeline of the intervention. In March 2015, the team collected yield expectations and field activities to date. Farmers were divided into 26 strata based on their location and agro-climatic conditions. ${ }^{16}$ Individual randomization was done at the stratum level and announced at the end of the March survey. ${ }^{17}$

A first mid-line survey was carried out in August 2015 focusing on labor inputs and agricultural practices to date during the growing season of the intervention. We also collected administrative data on fertilizer purchases from our partner agro-dealer. A second mid-line survey was fielded in October 2015, just before the harvest, to measure yield expectations and to record agricultural activities since the first mid-line. In January 2016, we collected yield data for the 2015 growing season. Finally, we collected further information on grain sales from the 2015 harvest in June 2016. In May 2017, 2 years after the experiment, we went back for a final end-line survey to collect information on practices for the 2017 growing season, which allow us to measure persistence. As a result, we have a panel on agricultural practices and input use for the years 2014, 2015 and 2017 and yield information for 2014 and 2015.

To be considered eligible for the program, farmers had to cultivate maize in at least one hectare of owned or rented land (and in no more than 15 hectares), had to be between 18 and 70 years old and had to sow maize in the 2015 growing season. We have consistent panel data on agricultural practices in 2014, 2015 and 2017 for 678 farmers and they comprise the core sample for the study. ${ }^{18}$

Table 2 provides summary statistics for the study sample of 678 farmers and their registered plots. Panel A reports farmer characteristics. Incomes were low by Mexican standards with an average self-reported annual income of 29,414 Pesos (2,200 USD). Panel B of Table 2 for all farmers and column 1 of Appendix Table A3 for farmers in the control group, report the agricultural practices at baseline. Farmers cultivate about 2 plots and an average total area of 5.7 hectares. In 2014 (the year before the intervention) fertilizer use in their registered plot was near universal (97\%) with farmers carrying out 1.6 fertilizations on average though only $6 \%$ fertilized at sowing. Average self-reported yields were about $2 \mathrm{mt} / \mathrm{ha}$ and about half sold maize in the market. Only $6 \%$ had used agricultural extension services in the past and only $15 \%$ had paid for a soil analysis.

16 Specifically, study farmers came from 54 localities (localidades) of which 29 were quite small and thus merged with the closest localidad using distance between centroids from INEGI's geographic databases. If there were ties, we chose to merge localidades with the closest altitude. Two of the small localidades were merged into one to give us a total of 26 clusters. The median cluster had 21 farmers, the 25th percentile had 15, and the 75th had 32.

${ }^{17}$ We note that with individual level randomization, there could be spillovers across farmers in different treatments. We study the potential spillovers in Section 5.2.

${ }^{18}$ We lack data for some farmers because they did not sow maize in a particular year (less than $5 \%$ ), or because they could not be located for the interview. Appendix Table A2 column 1 shows that attrition was not differential across experimental arms. 
Appendix Table A4 compares our study sample to respondents from the nationally representative INEGI survey, both in Mexico and in Tlaxcala. In Panel A we include all farmers, while Panel B restricts the sample to rainfed farmers. Study farmers have lower yields than both the national and the Tlaxcala sample. In terms of agricultural practices, study farmers are less likely to use hybrid seeds relative to the national average (but comparable to the Tlaxcala sample) and are more likely to have used fertilizer and herbicide than either of the INEGI samples. They are also more likely to have used extension services in the past. Panel B shows similar patterns, and both panels suggests that farmers with greater experience and perhaps those interested in improved inputs were more likely to select into the study.

\section{Experimental design}

The five experimental arms are a combination of three components: (a) soil analysis and recommendations (individual or averaged), (b) extension services and (c) and in-kind grants (conditional or unconditional) as outlined in the introduction. To summarize:

T1 : Individualized or plot-level soil analysis, input recommendations, extension services; inflexible in-kind grant.

T2 : Averaged or cluster-level soil analysis, input recommendations, extension services; inflexible in-kind grant. (i.e. same as T1 but with averaged instead of individual soil analyses and recommendations).

T3 : Averaged soil analysis, input recommendations, extension services; flexible in-kind grant. (i.e. same as $\mathbf{T} 2$ but with a flexible instead of inflexible in-kind grant).

T4 : Averaged soil analysis, input recommendations; extension services. (i.e. same as T3 or T2 but with no in-kind grant).

C : No intervention. Control Arm received averaged soil analysis and recommendations the year after the intervention ended (in early 2016).

Budgetary constraints prevented us from using a full factorial design with 18 experimental arms. ${ }^{19}$ As mentioned before, we chose to include agricultural extension services in all treatment arms because a pilot in the same study area with a comparable sample had suggested limited value of the soil analysis and recommendations without the extension services, as farmers appeared to greatly value the ability question and discuss the recommendations with the extension agents. Grants were provided in-kind (rather than in cash) for three reasons. First, because agro-dealers did not typically stock fertilizers in the blends required by the recommendations,

\footnotetext{
${ }^{19}$ These follow from the three possible choices of soil analysis and recommendations, two choices for extension services, and three choices for the grant intervention.
} 
we partnered with Agropecuaria Amozoc, who agreed to offer the tailored high-quality fertilizer packages to farmers as long as we guaranteed a minimum volume of sales. ${ }^{20}$ Second, the in-kind grant was intended as a "push" to farmers to experiment with higher quality inputs (fertilizers manufactured by a reputable high-quality firm). Finally and perhaps most importantly, cash grants were simply not possible because organizations such as QFD were not allowed by law to disburse cash grants. We next discuss the three sub-interventions in greater detail.

\subsection{Soil analysis and Specificity of Recommendations}

Soil analysis: The research team collected soil samples from the registered sub-plot of every study farmer (treatments and control). The samples were analyzed by Fertilab, a very well known and respected soil testing laboratory in Mexico. ${ }^{21}$ Online Appendix A provides details on the soil analysis protocol. The soil analysis recorded (for each plot) the soil texture (percentage of sand, silt and clay), its ability to retain and transfer nutrients ( $\mathrm{pH}$ levels, sand and lime concentrations, saturation points and cationic exchange capacity or CEC) as well as the levels of the primary macronutrients (nitrogen $\mathrm{N}$, phosphorous $\mathrm{P}$ and potassium $\mathrm{K}$ ), secondary macronutrients (calcium, magnesium, and sulfur), selected micronutrients and the level of organic matter in the soil. Figure OA1 in the Online Appendix provides an example of the soil analysis produced by Fertilab.

Recommendations: In addition to the soil analysis, Fertilab also provided the nutrient levels and corresponding fertilizer dosages required to produce maize yields of 4.5 metric tonnes per hectare (mt/ha) under normal rain and temperature conditions. Recommendations are based on a heuristic model that assumes that a certain quantity of N, P, K and micronutrients are needed to reach a target yield per hectare. ${ }^{22}$ In theory, the target yield should be chosen to maximize farmer profits. The model, however, assumes that yields are roughly linear in inputs and we therefore chose the target of $4.5 \mathrm{mt} /$ ha because it equated the average cost of fertilizers according to the model to the average expenditure in fertilizers by farmers at baseline.

\footnotetext{
${ }^{20}$ The dealer was able to blend fertilizers on-site. Packages were available for pick-up from the dealer store which was on average $17.2 \mathrm{~km}$ (s.d. 6.7) away from the average farmer. All study farmers had access to the dealer.

${ }^{21}$ Fertilab (https://www.fertilab.com.mx/) was recommended to us by CIMMYT staff.

${ }^{22}$ This assumption is grounded in the Law of the Minimum formulated by J.V. Liebig in the 1850s which suggests that to reach a target yield, a certain quantity of each nutrient is needed (similar to a Leontief production function). The Fertilab model uses this as well as a cost minimization approach given the price of available fertilizers. For example, for $\mathrm{N}$ one can use urea, DAP or ammonium sulfate. Taking into account the cost of the different fertilizers and the soil absorption capacity, the model selects the cheapest fertilizer package to meet the nutrient requirements. If the soil is $\mathrm{pH}$ negative (alkaline), then it is better to use ammonium sulfate rather than urea, but if the soil is $\mathrm{pH}$ positive (acid) then urea is preferred. There are other maize yield models such as CERES and NLEAP but many of the variables and parameters required by these models are unknown for Tlaxcala (and Mexico in general).
} 
The fertilizer dosages recommended by Fertilab were divided into two packages according to the timing of application: the first package to be applied at sowing, and the second 30 to 35 days after sowing depending on plant growth. Fertilab also recommended the use of a precision sowing drill at planting to ensure optimal fertilizer use at sowing as well as optimal plant spacing. Finally, the recommendations included the use of pre-emergent herbicides 2 to 40 days after sowing to reduce weeds that could compete for nutrients with the maize plants.

Based on focus group discussions, the research team used the information provided by Fertilab to design a report for farmers that was intuitive and easy to read. The report contained information on (a) plot physical characteristics and nutrient levels, (b) the recommended dosages of nutrients required to achieve a maize yield of $4.5 \mathrm{mt} /$ ha under normal weather conditions, (c) recommended fertilizer amounts and their costs at our partner agro-dealer and (d) a comparison between the farmer's own 2014 fertilizer costs the costs of the recommendations. The research team was careful to explain the assumptions underlying the recommendations. More details are available in Online Appendix B.

Specificity of recommendations: Given the potential heterogeneity in fertilizer recommendations within and across clusters, farmers in $T 1$ received individualized recommendations, based on the soil analysis from their registered subplot. The rest of the treated farmers in $T 2-T 4$ received recommendations based on averages of the soil analyses in their cluster. This averaging was expressly conveyed to them in the report as well as verbally when describing the recommendations. Control farmers received the average recommendations in February 2016, after the intervention had ended.

We assess the heterogeneity in input recommendations by running a standard analysis of variance (ANOVA) in Appendix Table A1. In particular, for registered subplot $i$ in cluster $c$ : $Y_{i c}=\mu+\alpha_{c}+\epsilon_{i c}$ and we report estimates of variation within $\left(\sigma_{\epsilon}\right)$ and across clusters $\left(\sigma_{\alpha}\right)$ and the share of the total variation arising from between cluster variation $\frac{\sigma_{\alpha}^{2}}{\sigma_{\alpha}^{2}+\sigma_{\varepsilon}^{2}}$. We find substantial variation in the soil characteristics (panel A) and nutrient recommendations (panel B) both within and across clusters although most of the variation appears to be within clusters.

These results are consistent with Figure 2 which displays the level of N, P and K in the registered plots for the four different agro-climatic areas of the study along with the target level of nutrients required to achieve $4.5 \mathrm{mt} / \mathrm{ha}$ according to the Fertilab model. The figure shows that even across different agro-climatic zones, the variation in nutrient content within each zone is much higher than across zones. In addition, Panel (a) of Figure 2 shows a deficit of $\mathrm{N}$ relative to the target level of $\mathrm{N}$ (red line) which is unsurprising because $\mathrm{N}$ is either absorbed by the plant, is lost to the atmosphere or lost via leaching or de-nitrification. Since soil analyses were taken right before sowing for the 2015 season, the $\mathrm{N}$ content in the soil should be relatively low. Panel (b) shows a soil level of $\mathrm{P}$ that is close to the target level and even higher in some plots, and therefore the recommendations call for relatively low amounts of the P rich fertilizer DAP. 
Finally, Panel (c) shows a significant deficit of $\mathrm{K}$ in the soil and thus the recommendations call for an increase of $\mathrm{K}$ fertilizer $\mathrm{KCl}$. In Appendix OA A.2 we discuss the stability over time of the soil analyses.

Column 1 of Table 3 presents the average amount of the three main fertilizers (urea, DAP and $\mathrm{KCl}$ ) and the total cost of application for farmers in the control group before the intervention in 2014. Column 2 reports the joint balance test that the 2014 amounts applied and costs by farmers in T1-T4 are not different than those in the control group. Column 3 reports the average amounts and cost that farmers in $T 1$ should apply in 2015 according to their plot-level individual recommendations. Column 4 in turn checks that the amounts and costs of applying the plot-level recommendations for farmers in $T 1$ are not different for those in the control group had the latter received the plot-level recommendations (note that the research team had the soil analysis and the recommendations for controls). Columns 5 and 6 are analogous to columns 3 and 4 for the average-level recommendations instead of plot-level ones. These results suggest that farmers in all five groups were quite similar in terms of fertilizer use in 2014 and in terms of recommended fertilizer packages (based on the soil analyses).

It is clear also clear from Table 3 that the mix of fertilizers traditionally used by farmers is quite different from the recommended mix when using either the plot-level or the clusterlevel recommendations. In particular, farmers in 2014 used 77\% (respectively, 92\%) more urea than required by the plot-level (cluster-level) recommendations. The corresponding overuse of DAP is equally striking $-61 \%$ (164\% for the averaged recommendations). In contrast to urea and DAP, farmers used only $28 \%(31 \%)$ of the recommended dose of $\mathrm{KCl}^{23}$ These differences between status quo fertilization and individually tailored recommendations are statistically significant as reported in column 8 of Table 3.

The total cost of fertilizer application for the individual recommendations is similar to the investment made by farmers in 2014 (p-value 0.55). This is unsurprising because, as mentioned earlier, the target yield of $4.5 \mathrm{mt} / \mathrm{ha}$ was chosen to equate the cost of the recommended fertilizer package with average farmers fertilizer costs. Plot-level recommendations use more fertilizer and are therefore more expensive than the cluster averaged recommendations. ${ }^{24}$ That individual recommendations are more expensive than average recommendations is not surprising because recommendations using soil analyses from multiple plots will have, on average, lower nutrient deficits and will thus require lower amounts of fertilizer (see Footnote 10).

Panel B of Table 2 reports that farmers in 2014 waited 36.3 days on average between sowing

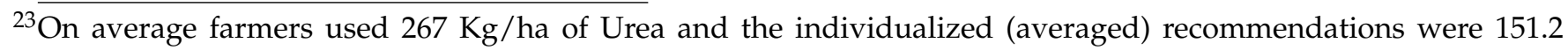
$\mathrm{kg} / \mathrm{ha}(138.9 \mathrm{~kg} / \mathrm{ha})$. Farmers used $49.4 \mathrm{~kg} / \mathrm{ha}$ of DAP while the individualized (averaged) recommendations were $30.6 \mathrm{~kg} / \mathrm{ha}(18.7 \mathrm{~kg} / \mathrm{ha})$. The corresponding figures for $\mathrm{KCl}$ are $9.45 \mathrm{~kg} / \mathrm{ha}$ and $33.3 \mathrm{~kg} / \mathrm{ha}$ (individualized) and $30.3 \mathrm{~kg} / \mathrm{ha}$ (averaged). Both urea and DAP are subsidized by the Mexican government which may explain why farmers use them in such large quantities.

${ }^{24}$ Column 7 reports the p-value of the t-test that individual recommendations in column 3 are equal to the average recommendations in column 5 . All p-values are statistically significant at conventional levels. 
and the first fertilizer application. The recommendations, however, suggest applying fertilizer at sowing with a precision drill. As a result, not only is the recommended input mix very different from what farmers use at baseline, but the timing of fertilizer application is also quite different, despite the fact that the cost of fertilizers is roughly the same. In our context, precision drills (which are tractor attachments) are the only implement that can sow and fertilize at the same time as they have separate chambers for seeds and fertilizer. However, only $11 \%$ of study farmers had used a precision drill prior to 2015. The majority used either draft animal labor $(40 \%)$ or a semi-precision drill $(40 \%)$. The semi-precision drill (also attached to a tractor) or the seed drill used with draft animals can only sow and thus, when used, farmers need to fertilize manually at sowing.

Fertilizer quality: In addition to differences in the fertilizer mix and timing, farmers were unfamiliar with the fertilizer brand YARA (a reputed, high-quality manufacturer) stocked by the agro-dealer. In order to assess fertilizer quality, the research team tested samples in a laboratory for each of the three main fertilizers (urea, DAP and $\mathrm{KCl}$ ) manufactured by YARA and by the most popular manufacturer (providing government subsidized fertilizer) from five different locations. ${ }^{25}$ We found that the urea and $\mathrm{KCl}$ content was comparable across the two types of manufacturer and generally matched the labelled concentrations. However, DAP concentrations were lower than advertised in the commonly available brand but this was not true for our partner agro-dealer. In fact after accounting for differences in concentrations, the cost per kilogram of nutrient was actually lower for YARA. See Online Appendix C for more details.

\subsection{Agricultural extension services}

Farmers were offered extension services at no cost from Ipampa S.C., a local, well-known and highly respected firm. The extension services package comprised three group training sessions and three plot visits by Ipampa agricultural extension workers (AEWs). The first group meeting introduced farmers to the precision sowing drill and covered the sowing recommendations. The second group meeting covered the application of fertilizer post-sowing and provided strategies to correct nutrient deficiencies. The final meeting was held just before the harvest and emphasized field preparation. In addition to these group meetings, AEWs also visited the registered subplots of interested farmers thrice, just before and after sowing and just before harvesting. AEWs used these individual visits to monitor nutrient deficiencies and other problems with the maize crop.

\footnotetext{
${ }^{25}$ The locations were Altlzayanca, Apizaco, Calpulalpan, Cuapiaxtla and Muñoz. The lab that analyzed the fertilizer content was Laboratorios A-L de México, in Guadalajara, México.
} 


\subsection{Autonomy in in-kind Grants}

Farmers were provided in-kind grants worth 2,000 pesos (approximately 150 U.S. dollars at the time) to cover approximately half of the average per-hectare total input costs, using prices from the last growing season. Farmers in $T 1$ and T2 received an inflexible grant in the sense that it could only be used to purchase items on their shopping list. The inflexible grant was applied sequentially to first cover the sowing costs (i.e. the rental cost of the precision sowing drill worth 800 pesos and the initial fertilizer package) while the remaining amount went towards the second fertilizer package. The farmer was responsible for paying the difference between the total cost of inputs and the grant. For the typical farmer in $T 1$ (T2 respectively), the grant covered the cost of the sowing machinery, the first fertilizer package and approximately onefifth (one-half) of the second fertilizer package. A farmer who chose not to rent the precision drill or to forego the first or second package would forfeit the subsidy for that input, that is, the farmers could not temporally reallocate the grant. Finally, farmers in $T 1$ and $T 2$ could not purchase fractions of the input recommendations (e.g. a half a bag). ${ }^{26}$

Farmers in T3 were offered a flexible grant, that is, they were not required to purchase items on the shopping list nor to follow the recommended timing of application. Instead, they had autonomy to use the 2,000 pesos to purchase any inputs of their own choice from our partner agro-dealer. They could, of course, use the grant to purchase items on the shopping list but were under no obligation to do so and this was made explicit during the intervention. Farmers in $T 4$, along with the rest in $T 1-T 3$, were informed about the high quality fertilizer agro-dealer, and given its address and a map. Farmers in $T 4$ had to pay for the rental as well as any recommended fertilizer and other inputs using their own funds. ${ }^{27}$

The grant amounts were directly given to the partner agro-dealer who deducted them from the costs of each farmer's shopping list. All farmers were informed about the in-kind grant both by the research team (in writing) as well as by the agro-dealer (and it was also reflected in the paper-work filled out by farmers at the dealer). The research team coordinated the logistics of renting the precision sowing drill for all interested farmers in T1-T4.

\subsection{Rationale for the interventions and hypotheses}

With the four treatment arms T1-T4 and the control group, we can directly test (1) the effect of pairing soil-analysis based tailored recommendations and extension services (T4 vs Control), (2) the effect of recommendation specificity ( $T 1$ vs $T 2$ ), (3) the effect of a in-kind grant (T1-T3 vs

\footnotetext{
${ }^{26}$ The inflexible grant is in effect the targeted input subsidy of many African large scale input subsidy programs. See e.g. Giné et al. (2019); Carter et al. (2019) for randomized evaluations in Tanzania and Mozambique, respectively, and Jayne and Rashid (2013) for a critical review of such programs.

${ }^{27}$ Precision and semi-precision drills are typically owned by local large landowners that use them on their plots but may also rent them on the side.
} 
T4), and (4) the effect of autonomy in the use of the grant (T3 vs T2). Comparisons (1), (2) and (4) are, to the best of our knowledge, new in the literature and we briefly review their rationale below.

Hypothesis 1 (H1): Extension services paired with tailored recommendations increases practice adoption relative to control farmers ( $T 4$ vs $C$ )

The extant research on providing farmers with tailored soil-analysis recommendations (e.g Harou et al., 2018) suggests limited adoption. However, such recommendations appear to be difficult to interpret and implement in isolation. We provide detailed soil analyses and recommendations (more detailed for instance than those provided by SoilDoc) and pair them with high quality extension services. The hypothesis is that the joint provision increases adoption.

Since control farmers received the recommendations at the start of the 2016 growing season, by the 2017 end-line survey, $T 4$ and $C$ differ only in that T4 received extension services (in 2015) and had tailored recommendations for a year longer than control farmers. We hypothesize that in 2017, extension services paired with tailored recommendations increase adoption more than tailored recommendations alone.

Hypothesis 2 (H2): Plot-level recommendations increases practice adoption relative to clusterlevel recommendations ( $T 1$ vs $T 2$ )

It seems reasonable that farmers are more likely to trust and therefore act on recommendations that are based on the soil quality of their own plots, especially if heterogeneity in soil quality is significant. In addition, previous research, albeit in a different setting (e.g. Madajewicz et al., 2007), suggests that individualized information is more effective. Cluster-level recommendations, however, are cheaper to produce and deliver, so if outcome differences between the two are small, then cluster averaged recommendations may be more cost-effective.

Given the substantial soil heterogeneity we document, our hypothesis is that individualized recommendations will induce more take up and adoption of practices.

There is an important caveat to this test. As we discussed above (see e.g. see p.3) the average cost of the plot-level recommendations was higher than that of the cluster-level recommendations (recall both recommendations calibrated for a yield of $4.5 \mathrm{mt} / \mathrm{ha}$ ). Holding costs constant would have required reducing target yields for the plot-level calibrations. Instead, we chose to keep target yields fixed for the calibrations (and hence had differing average costs).

\section{Hypothesis 3 (H3): The in-kind grant increases practice adoption (T1-T3 vs T4)}

The effect of the in-kind grant could work through multiple channels: (a) a direct income effect, (b) an endorsement effect (i.e. signalling that the team's specific recommendations were not just cheap talk) and (c) directly incentivizing experimentation. Since the tailored recommendations differed dramatically from business-as-usual, focus group discussions with farmers and 
talks with Ipampa S.C. suggested that some form of subsidy would be helpful for adoption. While we cannot separately identify the relative role of these (and other) mechanisms, we are somewhat skeptical that the in-kind grant operates mostly through an income effect since farmers were already spending an amount about equal to the grant amount on agricultural inputs before the intervention.

Hypothesis 4 (H4a): Adoption is higher in 2015 among farmers with the inflexible grant (T2) relative to farmers with the flexible grant $(\mathrm{T3})$. $(\mathrm{H} 4 \mathrm{~b})$ : Recommended practices are more likely to persist for farmers with the flexible grant relative to farmers with the inflexible grant.

Farmers with autonomy are encouraged to make an active decision with the flexible grant and thus may adopt fewer recommended practices than farmers offered the inflexible grant who risk forfeiting the grant amount if they reject the recommendations. However, the lack of choice may prove to be detrimental in the longer run. By virtue of being an active decision, and consistent with other studies showing that autonomy increases performance and positive affect, farmers offered the flexible grant may be more likely to persist with the practices that they do adopt.

\section{Empirical Framework}

We study the effects of our experimental interventions on the following outcomes for the 2015 intervention season: take up of subsidized inputs and extension services, agricultural practices, changes in the input mix, yields and profits. We also study longer term effects on agricultural practices, knowledge and attitudes towards innovation two years after the end of the program, in 2017.

We present the experimental results in two formats. First, we use a standard regression specification with indicator variables for each experimental arm (and omitting the control group when appropriate). Appendix Tables B1-B7 present the analysis using this specification where the coefficients on each indicator variable are interpretable as the effect of the corresponding treatment. The second format directly tests the hypotheses laid out in Section 3.4. Because each treatment arm is the combination of multiple interventions, we present the effects of their components rather than the treatment arms themselves. In this approach, we map the five arms into a set of five indicators variables: (a) "Extension" which is equal to one if the unit received input recommendations and extension services (T1-T4); (b) "IndRecomm", which is equal to one if the input recommendations were individualized at the plot level (T1); (c) "Grant", which is equal to one if the in-kind grant was provided (T1-T3) and (d) "Flexible", which is equal to one if the grant was flexible (T3). Table 4 summarizes the mapping between these dummies and those 
for each treatment arm. We then run the following specification:

$$
Y_{i t}=\beta_{0}+\beta_{E} \text { Extension }_{i}+\beta_{I} \text { IndRecomm }_{i}+\beta_{G} \text { Grant }_{i}+\beta_{F} \text { Flexible }_{i}+\alpha_{s}+\epsilon_{i t}
$$

where $i$ denotes a farmer, $Y$ is the outcome of interest and $t$ is the time period. We include randomization strata fixed effects $\alpha_{s}$ and compute robust standard errors.

Given the presence of the other indicators in specification (1), the coefficient $\beta_{E}$ on Extension compares outcomes for farmers in T4 relative to those in the control group (H1). It therefore measures the combined impact of the recommendations and agricultural extension services. $\beta_{I}$ measures the impact of recommendation specificity by comparing farmers offered plot-level recommendations (T1) with farmers in T2 who were offered cluster-level recommendations $(\mathrm{H} 2) ; \beta_{G}$ measures the impact of the in-kind grant on farmers in $T 2$, compared to farmers in $T 4$ (a subset of H3). Finally, $\beta_{F}$ measures the impact of autonomy by comparing farmers in $T 3$ with those in $T 2$ (H4). For completeness, in all results we also provide the p-value associated with the test that $T 1, T 2$ and $T 3$ are different from zero. ${ }^{28}$ Recall that the effect of flexibility/autonomy, and the effect of individual recommendations/specificity are measured in addition on the effect of the grant. Unless otherwise stated, we use the study sample of 678 farmers and we focus on intent-to-treat (ITT) estimates and examine spillovers (and hence possible SUTVA violations) in Section 5.2. In cases where the dependent variable is sometimes missing we report whether there is differential attrition, and if so, provide Lee bounds (Lee, 2009).

\section{Short-Term Results}

\subsection{Take up}

Table 5 uses the sample of farmers that received soil analyses and recommendations during the intervention (arms $T 1-T 4$ ) and examines the take up of the precision drill during sowing (column 1), the two fertilizer packages (columns 2 and 3), attendance at AEW group meetings and the total number of AEW plot visits (columns 5 and 6). Column 7 uses as the dependent variable the sum of the dependent variables in columns 1-3, 5 and 6 while column 8 uses a standardized index of the outcome in column 7 . The take up of these items was verified both from farmer reports as well as administrative data and as a result, mis-classification is not an important concern. The penultimate row of Table 5 also reports the mean of the dependent variable among farmers in $T 4$ (with the corresponding standard error). The control group is not included in these regressions as no intervention was offered to them.

\footnotetext{
${ }^{28}$ Note that we can recover the overall impact of being in any treatment arm by combining the $\beta$-coefficients. Thus, the test that $T 1=0$ is equivalent to $\beta_{E}+\beta_{I}+\beta_{G}=0, T 2=0$ is equivalent to $\beta_{E}+\beta_{G}=0$ and $T 3=0$ is equivalent to $\beta_{E}+\beta_{G}+\beta_{F}=0$. Finally, $T 4=0$ is equivalent to $\beta_{E}=0$, which is already reported.
} 
The take up of the precision drill among farmers without the in-kind grant (T4) was $8 \%$. Receiving the grant in addition increased the probability of take up (among farmers in T2) by 76 percentage points $(p p)$, a near ten-fold increase. Farmers that received the plot level recommendations (T1) are $67 p p$ more likely to adopt the precision drill compared to farmers in T4. Recall that farmers with the inflexible grant ( $T 1$ and $T 2$ ) forfeited the rental amount for the precision drill if they did not use it. This was not the case for farmers with the flexible grant (T3) as they could use the grant to purchase additional fertilizer or any other inputs available at the dealer. This is precisely what we observe: farmers with the flexible grant were $12 p p$ less likely than farmers with the inflexible grant (in $T 2$ ) to rent the precision drill, but as we shall see, they were more likely to adopt the first fertilizer package. ${ }^{29}$

The take up of the first fertilizer package (column 2) among farmers with just the recommendations and extension services (T4) is $7 \%$, but increases by $83 p p$ for farmers who in addition had an inflexible grant (in T2) - a more than ten-fold increase. The increases was comparably large, at $90 p p$, for farmers with the flexible grant. By contrast, the increase for farmers with the plot level recommendations (and the inflexible grant) was substantively smaller (74pp). Thus, the provision of plot level recommendations did not increase take-up of the package (relative to cluster level recommendations). This pattern is also reflected in other outcomes as we see below. Take-up rates for the second package (column 3) are somewhat lower than those for the first package: $4 \%$ for farmers who received just the recommendations and extension services (T4) and an increase of $74 p p$ for farmers who received the inflexible grant. Farmers with the flexible grant took up the second package at very similar rates (the treatment effect is $72 p p$ ) further evidence that grant flexibility did not decrease take up. As mentioned earlier, take-up rates for the second package among grant recipients are lower than those for the precision drill and the first package likely because the grant typically did not cover the full cost of the second fertilizer package (while it typically fully covered the costs of the sowing machinery rental and the first package). In fact, farmers in $T 2$ (T1 respectively) needed to pay 400 (700) pesos out-of-pocket to purchase the second package. Farmers in $T 2$ had to cover lower out-of-pocket amounts than those in $T 1$ because their recommendations were were on average cheaper. Column 4 shows these out-of-pocket expenses that farmers (with the grant) made to cover the cost of the second package. As expected, farmers with autonomy (T3) spend less than farmers in $T 2$ since they were less likely to use the precision sowing drill and so could use that subsidy amount towards the second package.

Turning next to extension services, columns 5 and 6 record the number of AEW led group sessions attended by the farmer and the number of visits by AEWs at farmer plots where the farmer was present, respectively. These sessions and plot visits were described in section 3 and

\footnotetext{
${ }^{29}$ While the first package should be applied at sowing with the precision drill to guarantee an optimal spread of fertilizer, farmers who did not use the precision drill were instead advised to use the first package 30-60 days after sowing depending upon plant growth.
} 
functioned as tutorials and question and answer sessions on best practices for maize cultivation. Farmers in T4 attended an average of 0.76 sessions (column 5) and had 1.4 plot visits (column 6). Farmers with the inflexible in-kind grant in $T 2$ attended 1.27 additional sessions and had 1.23 additional plot visits. Strikingly, farmers with the flexible grant attended 1.47 more sessions (relative to T4), about a fifth of a session more than farmers with the inflexible grant (the number of AEW plot visits were the same for both groups). Autonomy, therefore, seems to generate more engagement. ${ }^{30}$

Column 7 summarizes the previous columns by simply recording the total number of adopted program items (nine).$^{31}$ Farmers with just the recommendations and extension services adopted 2.34 items while farmers who also received the inflexible grant adopted an additional 4.83 items, confirming the importance of the in-kind grant. Interestingly, farmers with the flexible grant (i.e. who had no obligation to choose any of the nine items) adopted the same number of items on average as those who did not have autonomy - the point-estimate is in fact slightly higher (4.95). Thus, there was no trade-off between autonomy and compliance. In contrast, farmers with plot level recommendations adopted 0.76 fewer items compared to farmers in $T 2$. In particular, not only were $T 1$ farmers less likely to purchase the fertilizer packages than farmers in $T 2$ but they were also less likely to be present during AEW plot visits, which cannot be explained by budgetary reasons. Finally, column 8 reports results using a standardized index with analogous results (here measured in standard deviations). ${ }^{32}$

To summarize, farmers that received the in-kind grant were substantially more likely to takeup the recommended packages and to avail services relative to farmers who received only recommendations and extension services. Second, there appears to be little difference in take-up rates between farmers who had the flexible grant - and hence could have turned down all program offers without forfeiting the grant - and those who did not have this flexibility. Finally, we find no evidence that providing plot level recommendations increased take-up relative to providing cluster level recommendations. If anything, take-up was lower in $T 1$ than $T 2$ (by 0.62 s.d.).

\subsection{Practices in 2015}

We now turn to the adoption of agricultural practices recommended by the program. We partition them into those that were prevalent before the intervention (i.e. "Existing Practices") and those that were uncommon and that the intervention tried to promote (labelled "New Prac-

\footnotetext{
${ }^{30}$ The overall take up of the group training sessions declines over time with the most attendance around sowing and the least attendance before the harvest (results available upon request).

${ }^{31}$ These were the use of precision drill, 1st and 2nd fertilizer package, 3 group sessions and being present in the 3 plot visits by AEWs.

${ }^{32}$ Following the convention of standardizing each variable, summing the standardized variables, and restandardizing again so that the sum has mean zero and variance 1 in T4.
} 
tices").

Appendix Table A3 lists all of the recommended practices and reports their prevalence among farmers in the control group before (column 1) and during our intervention (in column 2). ${ }^{33}$ Column 3 reports the p-value of the test that adoption rates among controls are the same in 2014 and 2015. There are no substantial differences (the lowest p-value is 0.17), suggesting that spillovers between treated and control farmers during the intervention were limited. ${ }^{34}$

We aggregate practices for each of the two sets of practices into two corresponding indices to mitigate the need for multiple hypothesis testing. "Total Practices Applied" simply counts the number of adopted practices, while "Standardized Index" subtracts the control mean from the total number of practices applied and divides by the control standard deviation (for each element as well as the sum). Table 6 reports the results for the indices while Appendix Table A6 reports the result for the individual practices. Columns 1 and 2 of Table 6 show that our individual interventions had no effect on existing practices, which is unsurprising as the control mean for existing practices is quite high (2.4) as most farmers was already using all three practices.

Turning to new practices, farmers who received only the recommendations and extension services adopt an additional 0.35 practices compared to 0.32 practices in the control group, consistent with H1. Farmers who, in addition, were offered an inflexible grant (T2) adopt 2.56 more practices, an almost seven-fold increase and approximately the same increase as the 2.49 additional practices by farmers with a flexible grant (the numbers are not statistically distinguishable). Farmers offered plot level recommendations and the grant (T1) adopted about a third of a practice less than farmers in $\mathrm{T} 2$ so receiving plot level recommendations did not increase, and if anything lowered, compliance. These results reinforce the three patterns documented with program take up in the previous section: the importance of the in-kind grant (consistent with H3); the small negative role of plot level specificity (contra H2), and the fact that autonomy did not decrease adoption (contra H4a). The results for the standardized index of new practices in column 4 are consistent with those in column $3 .^{35}$

${ }^{33}$ Existing practices comprise ploughing (56\% in 2015), the use of inorganic fertilizers ( $97 \%$ ) and covering the applied
fertilizer ( $85 \%)$. New practices included deep tillage or ripping ( $5 \%$ in 2015$)$, using hybrid seeds $(5 \%)$, sowing with
a precision drill $(10 \%)$, fertilizing at sowing $(9 \%)$, application of pre-emergent herbicide $(2 \%)$ and using high-
quality fertilizers (manufactured by YARA) $(0 \%)$. We did not ask about covering the fertilizer, using high-quality
fertilizers or using pre-emergent herbicide after sowing at baseline, so they are only available in 2015 .
${ }^{34}$ Using the GPS coordinates, we also assessed whether control farmers with plots located close to those of treated
farmers (controlling for the total number of nearby study plots defined with reference to a $500 \mathrm{~m}$ or $1000 \mathrm{~m}$ radius)
are more likely to adopt the new practices. The intuition is that while the density of study farmers nearby is en-
dogenous, the share of those farmers that is treated is exogenous by virtue of randomization, and so if spillovers
were significant, one should detect larger changes in the adoption of recommended practices among control farm-
ers near treated farmers. We find no evidence of any such spillovers.
${ }^{35}$ We test whether the lower adoption of T1 (relative to T2) is due to proximity to other study farmers as disagree-
ment across recommendations results in lower willingness to follow their own recommendations. We examine
this hypothesis using again plot-level GPS locations. In particular, we examine whether farmers in T1 with plots
close to those of other treated farmers (controlling for the total number of plots from nearby study farmers) were 
In Table 7 we examine fertilizer usage. The primary outcome is the absolute difference between the amount of fertilizer applied and the amount recommended for each of the three main fertilizers (urea, DAP and $\mathrm{KCl}$ ). We expect treatments to reduce the gap between actual and recommended use. ${ }^{36}$ Columns 1-3 report application at sowing while columns 4-6 report total fertilizer application. For brevity we only focus on the results for the total fertilizer applied (the results for fertilizer at sowing are similar). ${ }^{37}$ Fertilizer usage did not change relative to controls for farmers who received only the recommendations and extension services (T4). By contrast and perhaps unsurprisingly, farmers who were, in addition, offered an inflexible in-kind grant (T2) - the bulk of which was earmarked for fertilizer - show a dramatic change in fertilizer application. The overall overall gap for urea reduced by $80.5 \mathrm{Kg} / \mathrm{ha}$ (a $71 \%$ reduction relative to the mean control value of $113 \mathrm{Kg} / \mathrm{ha}$ ), the gap in DAP by $29.5 \mathrm{Kg} / \mathrm{ha}$ (a $79 \%$ reduction) and the gap in $\mathrm{KCl}$ by $28.1 \mathrm{Kg} / \mathrm{ha}(87 \%)$. More interestingly, these dramatic reductions were also achieved by farmers with the flexible in-kind grant - who had autonomy and thus were not required to adjust their fertilizer usage as a pre-condition for the grant. In fact, we cannot reject the null that the reductions are the same for these two arms for Urea and DAP. For $\mathrm{KCl}$, the gap was reduced by $22.5 \mathrm{~kg} /$ ha for $T 3$, slightly less then for those offered the inflexible in-kind grant. Finally, farmers who received plot level recommendations had substantively and statistically similar reductions as the other two arms (again, except for $\mathrm{KCl}$ ).

In Appendix B and Appendix Table B8 we explore whether the changes in fertilizer use in 2015 were related to the gap between fertilizer used and recommended at baseline and whether there was variation in the effectiveness of the various treatments for a given baseline gap. We find that farmers with larger gaps were indeed more responsive to the treatments but that this responsiveness did not vary across treatment arms.

To summarize, we see a doubling of new agricultural practice adoption by farmers who re-

less likely to adopt intervention practices. Similarly, we assess whether farmers in $T 2-T 4$ close to other farmers in $T 2-T 4$ were differentially likely to adopt intervention practices (in this case all received the same average recommendations). We find no impact of spillovers defining nearby farmers as before, i.e. those within a $500 \mathrm{~m}$ or a $1,000 \mathrm{~m}$ radius.

${ }^{36}$ We also measure this gap for the control arm. As noted above, we performed soil analyses and recommendations for control plots but did not share these with control farmers in 2015.

${ }^{37}$ Recall that the recommendations encouraged farmers to change both the fertilizer mix and the timing of application. Since control farmers delayed the first fertilization by 36 days from the time of sowing on average (see panel B Table 2), columns 1 to 3 show a deficit of fertilizer application among controls of $38.7 \mathrm{Kg} /$ ha of urea, $19.4 \mathrm{Kg} / \mathrm{ha}$ of DAP and $16.4 \mathrm{Kg} / \mathrm{ha}$ of $\mathrm{KCl}$ at the time of sowing. Most farmers offered the in-kind grant (in T1-T3) used the precision drill and fertilized at sowing, reducing the absolute gap between recommendation and application at sowing. Among farmers with the flexible grant, these reductions were $28.5 \mathrm{Kg} / \mathrm{ha}$ of urea (a $74 \%$ reduction), 13.5 $\mathrm{Kg} / \mathrm{ha}$ of DAP (a 70\% reduction) and by $11.4 \mathrm{Kg} / \mathrm{ha}$ of $\mathrm{KCl}$ (a $70 \%$ reduction). The reductions are broadly similar for farmers in $T 1$ and $T 2$ as well. Farmers with the flexible grant did apply $3.5 \mathrm{Kg} / \mathrm{ha}$ less of urea compared to farmers in T2, thus increasing the gap between the amount of fertilizer recommended and applied (recall that urea was underused at sowing according to the recommendations). In column 3, farmers in $T 3$ also apply $3.4 \mathrm{Kg} / \mathrm{ha}$ less of $\mathrm{KCl}$ than farmers in $\mathrm{T} 2$, while farmers in $T 1$ with individual recommendations apply $1.8 \mathrm{Kg} / \mathrm{ha}$ of $\mathrm{KCl}$ less than farmers in $T 2$ as well. Thus, farmers in $T 2$ followed the fertilizer recommendations at sowing most closely, followed by farmers in $T 1$, then farmers in $T 3$. 
ceived recommendations and extension services only (relative to control), consistent with H1, but no change in their fertilizer input mix or timing of application. By contrast, farmers who also received the in-kind grant increased new practice adoption rates almost eight-fold and also changed both their fertilizer input mix and timing of application consistent with H3. In contradiction with $\mathrm{H} 2$, we find no evidence that specificity of the recommendations led to greater adoption, and finally, we find substantively similar patterns for farmers with and without autonomy, thus rejecting H4a as autonomy did not lead to lower adoption in 2015.

\subsection{Other outcomes in 2015}

We now turn to measuring the impact of the program on yields and profits. Self-reported yields are plagued by measurement error both in the numerator (the quantity harvested) as well as in the denominator (area sown). ${ }^{38}$ We took two steps to minimize this problem: first, the research team demarcated the registered subplot (which was one hectare in most cases) using GPS devices. ${ }^{39}$ Second, we attempted to verify self-reported yields by transporting the harvested grain to a nearby weighing station. We were able to do so for 498 of the 678 study sub-plots. ${ }^{40}$ Column 2 of Appendix Table A2 shows that the sample of 498 farmers with yield measurements is not random. To assess the magnitude of the selection problem, we use our measure of selfreported yields but restrict it to the sample of 498 plots with yield measurements. Interestingly, Appendix Table A7 finds very similar results between measured yields in column 1 and selfreported yields in column 2. We thus have confidence in our measure of self-reported yields.

After July, rainfall was below normal in all of the study municipalities, affecting the critical period for plant development. ${ }^{41}$ Appendix Table A8 shows that while the rainfall during the initial growing stages (before August) was similar in 2014, 2015 and 2016, total precipitation was significantly lower in 2015 compared to either 2014 or 2016. In both 2015 and 2016, we asked farmers whether they had suffered a drought and while in 2015, 73\% reported that they did, only $32 \%$ of the same respondents reported a drought in 2016. Finally, we collected yield expectations data in July and November of 2015. In Appendix Table A9 we regress the change in expected yields from July to November against an indicator for whether the respondent reported a drought. The results show that reporting a drought is associated with a decline of $170 \mathrm{Kg} / \mathrm{ha}$ in expected yields. Given that the sample is smaller than the core sample, we also

\footnotetext{
${ }^{38}$ See e.g. Desiere and Jolliffe (2017) for a discussion.

${ }^{39}$ For farmers with a plot area of less than 1 ha, the research team measured how much they had and adjusted the denominator appropriately. Results are robust to excluding these plots.

${ }^{40}$ For $75 \%$ of farmers, the crop was still standing at the time of the QFD visit, and the maize was harvested by QFD using a mechanical harvester. After harvesting, the team threshed the maize and transported it to be weighted. The remaining farmers had already harvested at the time of the visit but the production from the registered plot could be identified. In this case, after drying the maize the team visited the farmer with a mechanical sheller to collect the grain and transport it to be weighted. See Online Appendix D for details.

${ }^{41}$ See e.g. Sinclair and Rawlins (1993).
} 
report Lee bounds which indicate a decline in yields in the range $240 \mathrm{Kg} / \mathrm{ha}$ to $130 \mathrm{Kg} / \mathrm{ha}$. This suggests that the drought was severe enough to change yield expectations.

Column 1 in Table 8 presents the self-reported measure of yields for the full sample of 678 farmers. Yields for control farmers were $2,360 \mathrm{Kg} / \mathrm{ha}$. The provision of recommendations and extension services increased yields by $210 \mathrm{Kg} / \mathrm{ha}$ (a $9 \%$ increase relative to the control mean) but the estimate is not statistically significant at conventional levels. The in-kind grant, however, increased yields significantly (both in an economic and statistical sense) relative to those in the control group. For farmers with the inflexible in-kind grant and cluster level recommendations (T2), yields rose by $280 \mathrm{Kg} / \mathrm{ha}$ (a $12 \%$ increase relative to the control mean). The corresponding treatment effect for farmers who received the flexible grant was $360 \mathrm{Kg} / \mathrm{ha}$ (a 15\% increase). The two numbers are not statistically distinguishable, and our conclusion is that providing farmers with autonomy, did not decrease yield or profits. Yields for farmers with plot level recommendations (T1) rose by $400 \mathrm{Kg} / \mathrm{ha}$ (a $17 \%$ increase), but given the standard errors, this is not statistically different from the yields for arms $T 2$ or $T 3 .{ }^{42}$

While the results on yields are encouraging, it is perhaps more important to evaluate impacts on profits. Measuring and valuing both inputs and output, however, is extremely challenging for smallholder farmers (see e.g. Foster and Rosenzweig, 2010). We measured revenues and expenditures on a comprehensive set of agricultural inputs using frequent, detailed surveys throughout the growing season. ${ }^{43}$ To calculate revenues we multiplied the price received in the sale of maize by the self-reported quantity harvested. ${ }^{44}$ Revenues are reported in column 2 and not surprisingly, show a similar pattern to that for yields in column 1. Expenditures are reported in column 3. For each stage of the growing season - soil preparation, sowing, plant maintenance, and harvesting - we measured labor days in the one hectare subplot, whether it was provided by a family member or hired-in labor, and the wage paid for hired labor. We also measured other inputs, including seeds, fertilizers, sowing machinery, pesticides, herbicides, and harvest machinery and whether the cost was paid by the farmer or by the research team (i.e. we include the up to 2,000 peso subsidy in the costs and impute harvesting costs if they were paid by the research team). ${ }^{45}$ Column 3 shows that grant recipients in $T 2$ invested 623 more pesos/ha than farmers in $T 4$ or the control group, who spent on average 5,280 pesos/ha. Column 4 reports profits as the difference between revenues and costs. Although all the point estimates are positive - and suggest profit increases in the range of 10\% (T3), $12 \%$ (T2), $20 \%$

${ }^{42}$ In fact, we cannot reject the joint null hypothesis that the treatment effects are the same for all three arms (T1, T2 and T3).

${ }^{43}$ Enumerators from each of the seven teams lived less than a thirty minutes drive from the study plots assigned to them. Plots were visited several times by the team during the year. Unpaid labor is however not taken into account in our calculations because of the difficulty in imputing a shadow wage.

${ }^{44}$ Only about $70 \%$ of farmers sold maize, and we imputed the price of maize for the remaining farmers using the median price in their cluster.

${ }^{45}$ Appendix Table A10 disaggregates expenditures into different categories. Note however, that we do not value unpaid (typically family) labor in labor costs. 
(T1) and 23\% (T4) - they are imprecisely estimated and none of the estimates are significant at conventional levels. In column 5, we remove the amount of subsidy and harvesting costs paid by the program from the costs to consider only the out-of-pocket investment made by each farmer. We find, unsurprisingly, an increase in profits in the range of 2,300 pesos/ha among farmers with the grant ( $T 1, T 2$ and $T 3$ ) relative to control farmers as well as farmers in $T 4$.

\section{Long-Term Practice Persistence}

In February 2016, after the conclusion of the harvest, farmers in the control group received cluster averaged soil analyses and recommendations. We subsequently returned in the summer of 2016 for a short survey where we asked farmers if they still had a copy of their recommendations. Even though the control group had only received their recommendations a few months earlier, they were substantially less likely to have it on hand (58\%) than farmers who had also received extension services in 2015 (87\%) - the figures were comparably high for the other arms as well. We returned in May 2017 to examine whether any of the practices introduced in 2015 had persisted into the second growing season after the intervention. The survey took place after sowing (but prior to harvest) and we asked about a range of outcomes, including practices in the 2017 season and agricultural knowledge.

Table 9 shows the results on adoption of practices in 2017. Turning to new practices in Column 3, control group farmers reported using 0.42 new practices on average, statistically indistinguishable from the 0.32 new practices used by the same group in the year of the intervention, suggesting that the provision of only the soil analyses and recommendations a year later (without extension services) did little to change practices, and that spillovers from treatment farmers were likely minimal. ${ }^{46}$ Farmers in $T 4$ who had also received extension services in 2015 adopted 0.24 additional practices - an increase of 0.39 s.d. (Columm 4). Thus, the provision of extension services had persistent effects into the second growing season relative to controls consistent with hypothesis $\mathrm{H} 1$ for $2017 .{ }^{47}$ We view this as encouraging evidence of the longer-term effectiveness of extension services when paired with soil analysis based recommendations. Farmers who, in addition to the recommendations and services, were offered an inflexible grant (T2) adopt 0.33 more practices (statistically indistinguishable from the treatment effect for T4) and farmers who received plot-level recommendations adopted 0.46 more practices. However, we cannot reject the null hypothesis that the treatment effect is the same for all three arms (the p-value is 0.59 , see Table B5).

\footnotetext{
${ }^{46}$ Note also that control farmers were much less likely to have a copy of the recommendations on hand when asked by surveyors.

${ }^{47}$ Since farmers in $T 4$ received their analyses an recommendations a year before the control group, the differences in outcomes between them and the controls reflect both the effect of the extension services as well as the effect of having had the recommendations for an extra year.
} 
More interestingly, farmers who had received the flexible grant adopted 0.78 more practices (a 1.08 standard deviation increase), substantively more than farmers with the inflexible grant in T2. Thus farmers with autonomy were more likely to persist with new practices introduced by the project two years after the intervention ended, consistent with H4b. In order to examine this result in greater detail we turn to the individual practices reported in Appendix Table A11. In 2017, farmers in T3 are more likely (than those in T2) to use hybrid seeds, sow with a precision drill and use YARA fertilizers. Intriguingly, while the rental of the precision drill and YARA fertilizers were subsidized by the in-kind grant, hybrid seeds, while recommended, were not subsidized. It thus appears that farmers with the flexible grant during the intervention perhaps spent more time evaluating different options and made decisions accordingly - adopting in 2017 some practices that were mandatory for farmers in T1 and T2 in 2015 and others that were not.

\subsection{Understanding the role of Autonomy}

In this subsection we seek to better understand the reasons for adoption by farmers with autonomy, both during as well as after the intervention. As noted above, although farmers with autonomy were not required to follow any of the intervention recommendations, most did so and at rates comparable to those of farmers without autonomy. This was true both for the purchase of inputs (precision drill, fertilizer) as well as extension services (AEW training sessions and plot visits) which were free of charge. It appears that during the intervention farmers with autonomy trusted the recommendations enough to follow them without being required to do so and that this effect persisted into subsequent growing seasons.

We provide two pieces of evidence in support of hypothesis H4a and H4b in Tables 10 and 11. First and most directly, we find that during the intervention farmers with autonomy (i.e. the flexible grant) were 0.35 standard deviations more likely to report trusting recommendations from the implementing partners (Ipampa and the local input supplier) relative to farmers with the inflexible grant in $T 2 .{ }^{48}$ Second, we find that farmers with autonomy were more likely to report remembering the recommendations and state that they would follow them in the next growing season: farmers in $T 3$ were $5 p p$ more likely to report that they remembered the sowing recommendations (relative to farmers in T2) and 14pp more likely (than farmers in T2) in 2016 to report intending to follow the program recommendations in the next growing season. Finally in 2017, farmers with autonomy expressed the highest willingness to pay for (high-quality) $\mathrm{KCl}$, the least known and used fertilizer at baseline, and hence the one whose increased usage was most recommended by the program (Table 11). Consistent with laboratory studies showing that greater autonomy increases effort, we find a $6 \%$ increase in hired labor when the grant is

\footnotetext{
${ }^{48}$ Trust was measured on a five-point Likert scale that ranged from "Always trust" to "Never trust." See Appendix Table A12 for definition of the variables.
} 
flexible compared to when it is inflexible (Column 5 of Table 10).

Farmers with autonomy also evinced a more open attitude towards change and experimentation. ${ }^{49}$ In 2017 , farmers in $T 3$ are 0.27 s.d. more likely to exhibit a positive attitude towards change compared to farmers in $T 2$. This last finding is interesting since it is consistent with the flexible grant leading to a willingness to experiment (perhaps by giving farmers a greater sense of agency). Such inferences, although speculative, do suggest fruitful areas for further research.

To summarize, farmers with the flexible grant in 2015 were more likely to exhibit increased knowledge of and trust in the program after it ended and display a more positive attitude towards experimentation. These changes could help explain why we see a greater persistence in program practices among this group two years after the program ended.

\section{Conclusion}

Encouraging technology adoption in agriculture among smallholder farmers is an active area of research and a first-order policy issue. In this paper we test several hypotheses on the role of information in technology adoption that explicitly recognize the importance of heterogeneity in soil quality for best practices. We conduct detailed soil analyses and document substantial heterogeneity in soil quality, even within relatively small clusters, and correspondingly heterogeneous optimal recommendations for fertilizer usage. We show that farmers' current fertilizer application practices deviate markedly from the localized ones both in input mix as well as timing (with a substantial overuse of urea and DAP).

We conduct a randomized experiment with a control and four treatment arms that provided a combination of localized soil analyses, recommendations and extension services, and an inkind grant. We vary the level of recommendation specificity (plot level versus cluster level) and the degree of autonomy in the usage of the grant (flexible versus inflexible). The experimental design allows us to credibly test the effects of (a) pairing localized recommendations with extension services, (b) recommendation specificity, (c) an in-kind grant and (d) autonomy, with (a), (b) and (d) being, to the best of our knowledge, novel to the literature.

We document that varying the level of recommendation specificity had little effect on outcomes both in the short and longer-term so that there is no downside in choosing to provide cheaper recommendations based on cluster (localidad) level soil analyses relative to more expensive plot-level recommendations, even in a context with substantial heterogeneity. We find that pairing localized recommendations with extension services had modest but persistent ef-

\footnotetext{
${ }^{49}$ We measure this using a standardized index of five questions described in Appendix C (non-cognitive measures) of Laajaj and Macours (2017). Openness is measured by affirmative answers to agriculture specific issues (e.g. to statements such as "When you are presented with a new agricultural technology, you are willing to try it first", "In your plots, you prefer to try something new") as well as more general views about experimentation (e.g. "Generally speaking, you prefer to try new things").
} 
fects on agricultural practices. Adding the in-kind grant had important short-term effects with improved practice adoption and productivity but only during the intervention, with adoption returning to pre-intervention levels afterwards.

However, we find that farmers with greater autonomy (defined as the ability to choose how the in-kind grant was spent) showed substantially greater persistence relative to farmers without such autonomy. We provide some evidence that farmers with greater autonomy reposed greater trust in the project partners, remembered the recommendations better and also exhibited a more positive attitude towards experimentation after the intervention ended. The results suggest an important instrumental role for autonomy in increasing adherence to externally provided recommendations. We consider examining the interaction between the exercise of autonomy and the adherence to expert advice a fruitful avenue for research.

\section{References}

Anderson, J. R. and Feder, G. (2007). Agricultural Extension. Handbook of Agricultural Economics, 3:23432378. [4]

Ashraf, N., Giné, X., and Karlan, D. (2009). Finding Missing Markets (and a disturbing epilogue): Evidence From an Export Crop Adoption And Marketing Intervention in Kenya. American Journal of Agricultural Economics, 91(4):973-990. [1]

Baird, S., McIntosh, C., and Özler, B. (2019). When The Money Runs Out: Do Cash Transfers Have Sustained Effects On Human Capital Accumulation? Journal of Development Economics, 140:169 - 185. [6]

Bardhan, P. (2000). Irrigation and Cooperation: An Empirical Analysis Of 48 Irrigation Communities In South India. Economic Development and Cultural Change, 48(4):847-865. [5]

Bartling, B., Fehr, E., and Herz, H. (2014). The intrinsic value of decision rights. Econometrica, 82(6):20052039. [2]

Beaman, L., BenYishay, A., Magruder, J., and Mobarak, A. M. (2018). Can Network Theory-Based Targeting Increase Technology Adoption? Technical report, National Bureau of Economic Research Paper 24912. [4]

Benhassine, N., Devoto, F., Duflo, E., Dupas, P., and Pouliquen, V. (2015). Turning A Shove Into A Nudge? A "Labeled Cash Transfer" For Education. American Economic Journal: Economic Policy, 7(3):86-125. [6]

Black, S. E. and Lynch, L. M. (2001). How to Compete: The Impact of Workplace Practices and Information Technology on Productivity. The Review of Economics and Statistics, 83(3):434-445. [5]

Bloom, N., Eifert, B., Mahajan, A., McKenzie, D., and Roberts, J. (2013). Does management matter? evidence from india. The Quarterly Journal of Economics. [3, 4]

Bold, T., Kaizzi, K. C., Svensson, J., and Yanagizawa-Drott, D. (2017). Lemon Technologies And Adoption: Measurement, Theory And Evidence From Agricultural Markets In Uganda. The Quarterly Journal of Economics, 132(3):1055-1100. [1]

Bonin, J. P., Jones, D. C., and Putterman, L. (1993). Theoretical And Empirical Studies Of Producer Cooperatives: Will Ever The Twain Meet? Journal Of Economic Literature, 31(3):1290-1320. [5] 
Carter, M., Laajaj, R., and Yang, D. (2019). Subsidies And The African Green Revolution: Direct Effects And Social Network Spillovers Of Randomized Input Subsidies In Mozambique. Working paper. [13]

Cole, S. A. and Fernando, A. N. (2020). 'Mobile'izing Agricultural Advice: Technology Adoption, Diffusion, and Sustainability. [4]

Conley, T. G. and Udry, C. R. (2010). LearnIng About A New Technology: Pineapple In Ghana. American Economic Review, 100(1):35-69. [1]

Dal Bó, P., Foster, A., and Putterman, L. (2010). Institutions And Behavior: Experimental Evidence On The Effects Of Democracy. American Economic Review, 100(5):2205-29. [5]

Desiere, S. and Jolliffe, D. (2017). Land Productivity And Plot Size: Is Measurement Error Driving The Inverse Relationship? Technical report, The World Bank. [21]

Duflo, E., Kremer, M., and Robinson, J. (2011). Nudging Farmers To Use Fertilizer: Theory And Experimental Evidence From Kenya. American Economic Review, 101(6):2350-90. [1, 5]

Emerick, K., de Janvry, A., Sadoulet, E., and Dar, M. H. (2016). Technological Innovations, Downside Risk, And The Modernization Of Agriculture. American Economic Review, 106(6):1537-61. [1]

Fernández, A. T., Wise, T. A., and Garvey, E. (2012). Achieving Mexico's Maize Potential. Global Development and Environment Institute Working Paper 12-03. [1]

Ferreira, J. V., Hanaki, N., and Tarroux, B. (2020). On The Roots Of The Intrinsic Value Of Decision Rights: Experimental Evidence. Games and Economic Behavior, 119:110-122. [2]

Fishman, R., Kishore, A., Rothler, Y., Ward, P. S., Jha, S., and Singh, R. K. P. (2016). Can Information Help Reduce Imbalanced Application Of Fertilizers In India? Experimental Evidence From Bihar. IFPRI Discussion Paper 01517. [4]

Fiszbein, A. and Schady, N. (2009). Conditional Cash Transfers: Reducing Present and Future Poverty. World Bank, Washington, DC. [6]

Fitzsimons, G. J. and Lehmann, D. R. (2004). Reactance to Recommendations: When Unsolicited Advice Yields Contrary Responses. Marketing Science, 23(1):82-94. [5]

Foster, A. and Rosenzweig, M. (2010). Microeconomics of Technology Adoption. Annual Review of Economics, 2(1):395-424. [1, 22]

Giné, X., Cole, S., and Vickery, J. (2017). How Does Risk Management Influence Production Decisions? Evidence From A Field Experiment. Review of Financial Studies, 30(6):1935-1970. [1]

Giné, X., Patel, S., Ribeiro, B., and Valley, I. (2019). Targeting Inputs: Experimental Evidence from Tanzania. Working paper, World Bank. [13]

Goyal, A. and Nash, J. (2017). Reaping Richer Returns: Public Spending Priorities for African Agriculture Productivity Growth. World Bank, Washington, DC. [1]

Harou, A. P., Madajewicz, M., Magomba, C., Michelson, H., Tschirhart, K., Amuri, N., and Palm, C. (2018). Can Information Improve Investment? Effects Of Site-Specific Soil Recommendations On Fertilizer Demand. Working paper. [5, 14]

Jayne, T. S. and Rashid, S. (2013). Input Subsidy Programs In Sub-Saharan Africa: A Synthesis Of Recent Evidence. Agricultural Economics, 44(6):547-562. [1, 13]

Karlan, D., Osei, R., Osei-Akoto, I., and Udry, C. (2014). Agricultural Decisions After Relaxing Credit And Risk Constraints. The Quarterly Journal of Economics, 129(2):597-652. [1]

Kondylis, F., Mueller, V., and Zhu, J. (2017). Seeing Is Believing? Evidence From An Extension Network Experiment. Journal of Development Economics, 125(February 2015):1-20. [4]

Laajaj, R. and Macours, K. (2017). Measuring Skills In Developing Countries. Working paper, The World Bank. [25] 
Lee, D. S. (2009). Training, Wages, and Sample Selection: Estimating Sharp Bounds on Treatment Effects. The Review of Economic Studies, 76(3):1071-1102. [16]

Macours, K. (2019). Farmers' Demand and the Traits and Diffusion of Agricultural Innovations in Developing Countries. Annual Review of Resource Economics, 11(1):483-499. [1]

Madajewicz, M., Pfaff, A., van Geen, A., Graziano, J., Hussein, I., Momotaj, H., Sylvi, R., and Ahsan, H. (2007). Can Information Alone Change Behavior? Response To Arsenic Contamination Of Groundwater In Bangladesh. Journal of Development Economics, 84(2):731-754. [1, 14]

Magruder, J. R. (2018). An Assessment of Experimental Evidence on Agricultural Technology Adoption in Developing Countries. Annual Review of Resource Economics, 10(1):299-316. [1, 4]

Malesky, E. and Taussig, M. (2019). Participation, Government Legitimacy, And Regulatory Compliance In Emerging Economies: A Firm-Level Field Experiment In Vietnam. American Political Science Review, 113(2):530-551. [5]

Marenya, P. P. and Barrett, C. B. (2009). State-Conditional Fertilizer Yield Response On Western Kenyan Farms. American Journal of Agricultural Economics, 91(4):991-1006. [5]

Molina-Millán, T., Barham, T., Macours, K., Maluccio, J. A., and Stampini, M. (2019). Long-term Impacts Of Conditional Cash Transfers: Review Of The Evidence. The World Bank Research Observer, 34(1):119159. [6]

Munshi, K. (2004). SOcial Learning In A Heterogeneous Population: Technology Diffusion In The Indian Green Revolution. Journal of Development Economics, 73(1):185 - 213. [1]

Murphy, D. M. A., Roobroeck, D., Lee, D. R., and Thies, J. (2019). Underground Knowledge: Estimating the Impacts of Soil Information Transfers through Experimental Auctions. Working paper. [4]

Otsuka, K. and Larson, D. (2013). An African Green Revolution. Springer. [1]

Restuccia, D. and Rogerson, R. (2017). The causes and costs of misallocation. Journal of Economic Perspectives, 31(3):151-174. [5]

Sen, A. (1999). Development as Freedom. Oxford University Press. [2]

Sheahan, M., Black, R., and Jayne, T. (2013). Are Kenyan Farmers Under-Utilizing Fertilizer? Implications For Input Intensification Strategies And Research. Food Policy, 41:39-52. [5]

Sinclair, T. R. and Rawlins, S. L. (1993). Inter-Seasonal Variation In Soybean And Maize Yields Under Global Environmental Change. Agronomy Journal, 85(2):406-409. [21]

Sjöström, T., Ulku, L., and Vadovic, R. (2018). Free to Choose: Testing the Pure Motivation Effect of Autonomous Choice. Available at SSRN 3291646. [5]

Spector, P. E. (1986). Perceived Control By Employees: A Meta-Analysis Of Studies Concerning Autonomy And Participation At Work. Human relations, 39(11):1005-1016. [5]

Suri, T. (2011). Selection And Comparative Advantage In Technology Adoption. Econometrica, 79(1):159209. [1]

Sweeney, S., Steigerwald, D. G., Davenport, F., and Eakin, H. (2013). Mexican Maize Production: Evolving Organizational And Spatial Structures Since 1980. Applied Geography, 39:78-92. [1]

Tjernström, E. (2017). Learning from Others in Heterogeneous Environments. Technical Report April. [4]

Wang, Z.-H. and Li, S.-X. (2019). Nitrate $\mathrm{N}$ loss by leaching and surface runoff in agricultural land: A global issue (a review). Advances in Agronomy, 156:159. [5]

Wicklund, R. A. (1974). Freedom and Reactance. Lawrence Erlbaum. [5]

World Bank (2008). World Development Report 2008: Agriculture for Development. World Bank, Washington, DC. [1] 


\section{Tables and Figures}

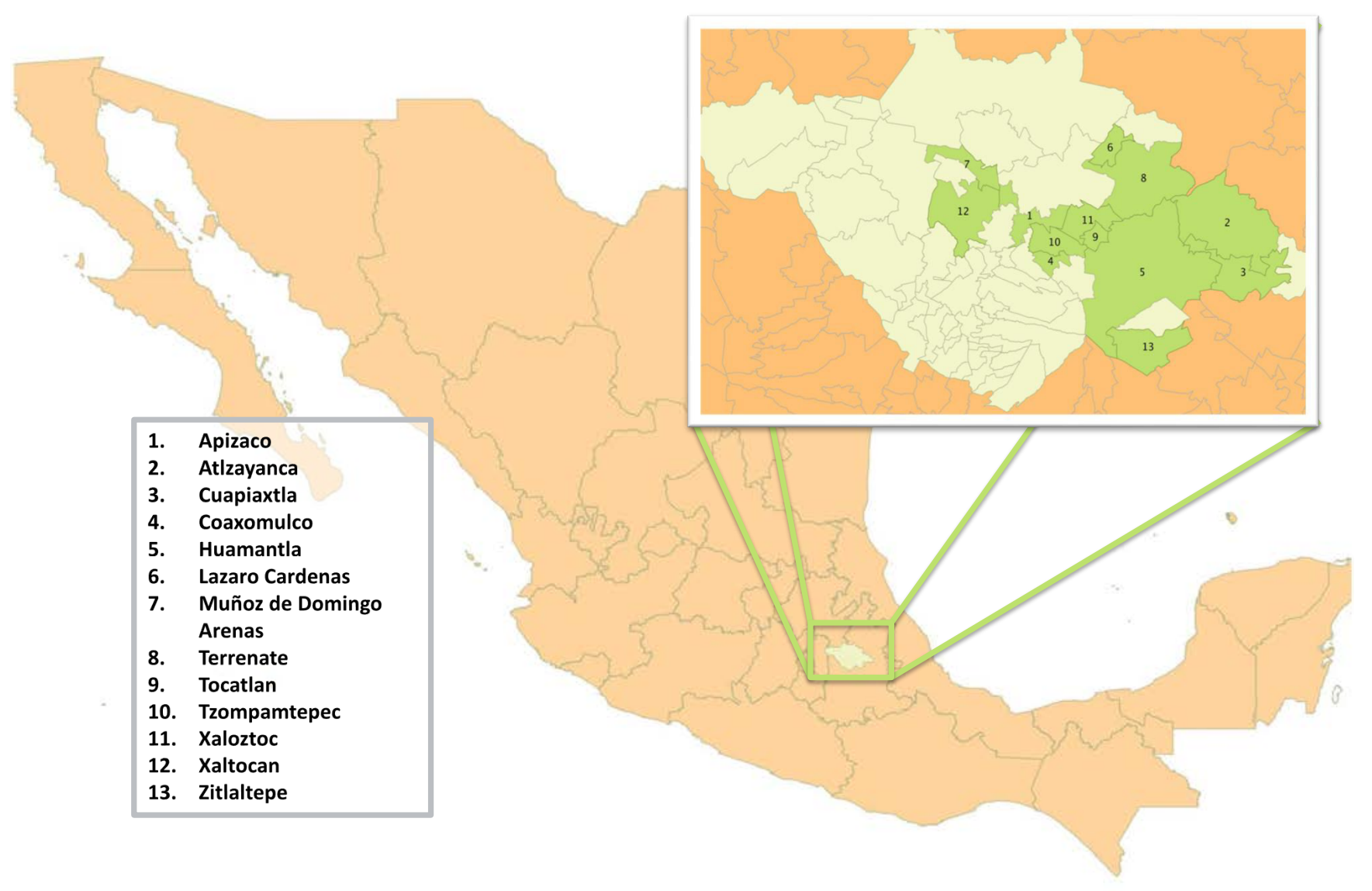

Figure 1: Map of Tlaxcala 


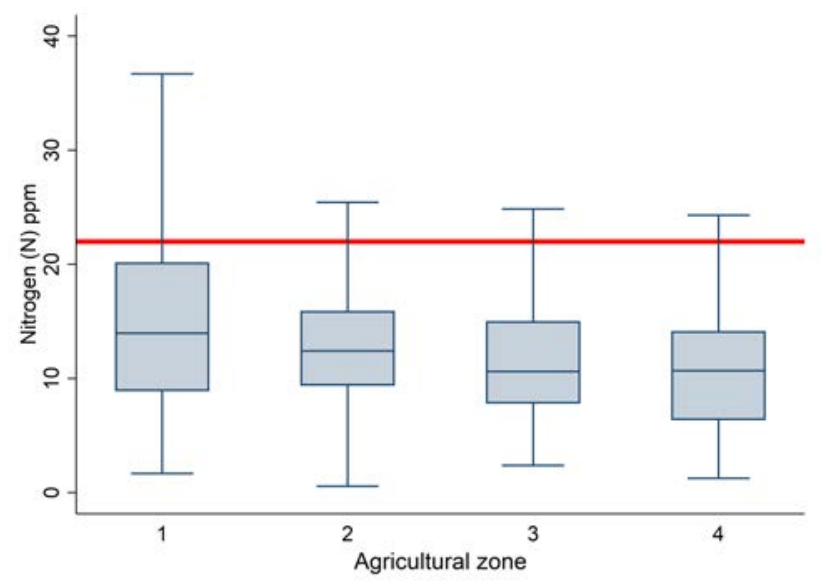

(a) Nitrogen $(\mathrm{N})$

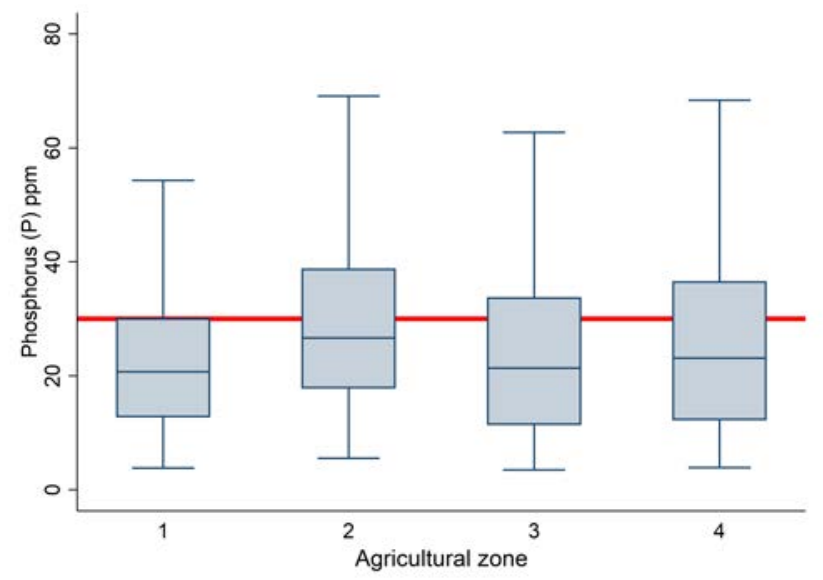

(b) Phosphorus (P)

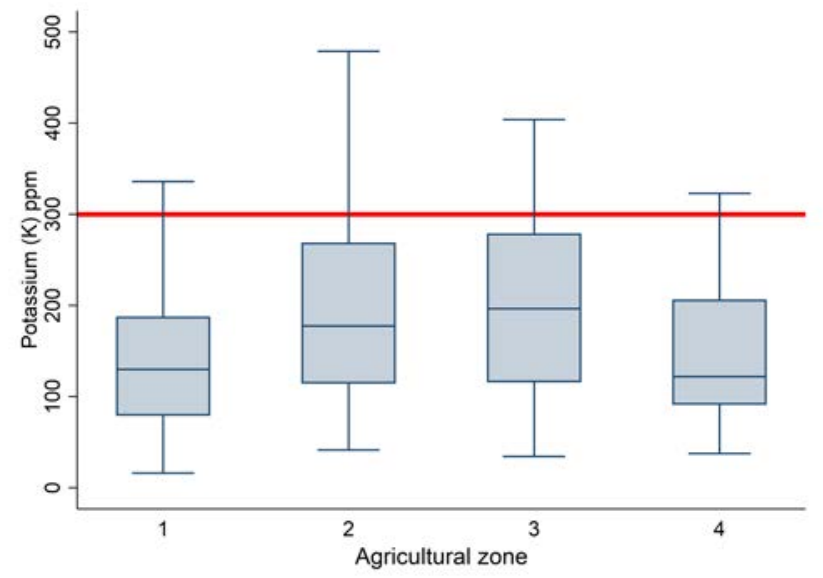

(c) Potassium (K)

Figure 2: Soil nutrients and target amounts

Note: this figures displays boxplots with distributions of different soil macronutrients across the 4 agricultural zones of Tlaxcala in our study. We use data from the soil analysis of farmers in our study sample. Sub-figures (a), (b) and (c) report data on Nitrogen, Phosphorus and Potassium. In each of the subfigures, we also report the average amounts of nutrients that farmers needed in their plots to reach the $4.5 \mathrm{ton} / \mathrm{ha}$ goal associated with our fertilizer recommendations. All values are reported in part-per-million (ppm) units. 
Table 1: Timeline of Activities

\begin{tabular}{cl}
\hline \hline $\begin{array}{c}\text { Season/Date } \\
\text { Pre-planting 2015 }\end{array}$ & Activity \\
$\begin{array}{c}\text { January 2015 } \\
\text { February 2015 }\end{array}$ & $\begin{array}{l}\text { Farmer Registration } \\
\text { Soil sampling } \\
\text { Baseline survey (farmer characteristics } \\
\text { and 2014 practices) }\end{array}$ \\
Planting 2015 & $\begin{array}{l}\text { Delivery of soil analysis } \\
\text { Orders of fertilizers }\end{array}$ \\
\hline March 2015 & $\begin{array}{l}\text { Intervention } \\
\text { Follow-up survey (2015 practices) }\end{array}$ \\
Augril-July 2015 2015 & $\begin{array}{l}\text { Yield estimation } \\
\text { 2015 Self-reported yields survey }\end{array}$ \\
\hline October-December 2015 & \\
February 2016 & $\begin{array}{l}\text { 2015 Commercialization survey } \\
\text { (prices, sales and costs) }\end{array}$ \\
\hline June 2016 & Follow-up survey (2017 practices) \\
\hline Planting 2017 &
\end{tabular}









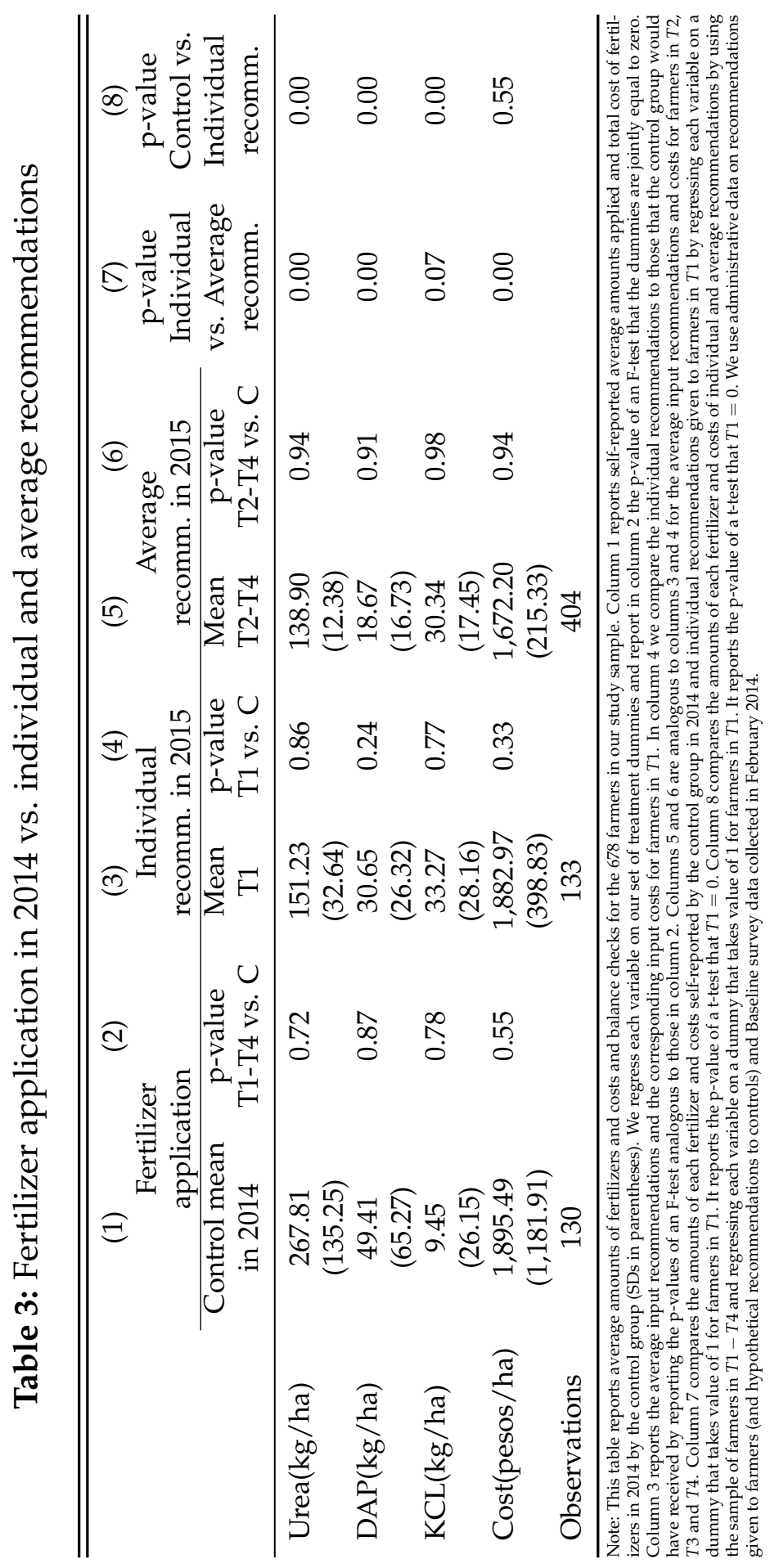


Table 4: Definition of dummies

\begin{tabular}{|c|c|c|c|c|}
\hline & Extension & $\begin{array}{l}\text { Individual } \\
\text { recommendation }\end{array}$ & Grant & Flexible \\
\hline$T 1$ & Yes & Yes & Yes & $\mathrm{No}$ \\
\hline$T 2$ & Yes & No & Yes & No \\
\hline T3 & Yes & No & Yes & Yes \\
\hline$T 4$ & Yes & No & No & No \\
\hline$C$ & No & No & No & No \\
\hline Hypothesis & H1 & $\mathrm{H} 2$ & H3 & $\mathrm{H} 4 \mathrm{a}, \mathrm{H} 4 \mathrm{~b}$ \\
\hline Test & $T 4=C$ & $T 1=T 2$ & $T 2=T 4$ & $T 2=T 3$ \\
\hline
\end{tabular}




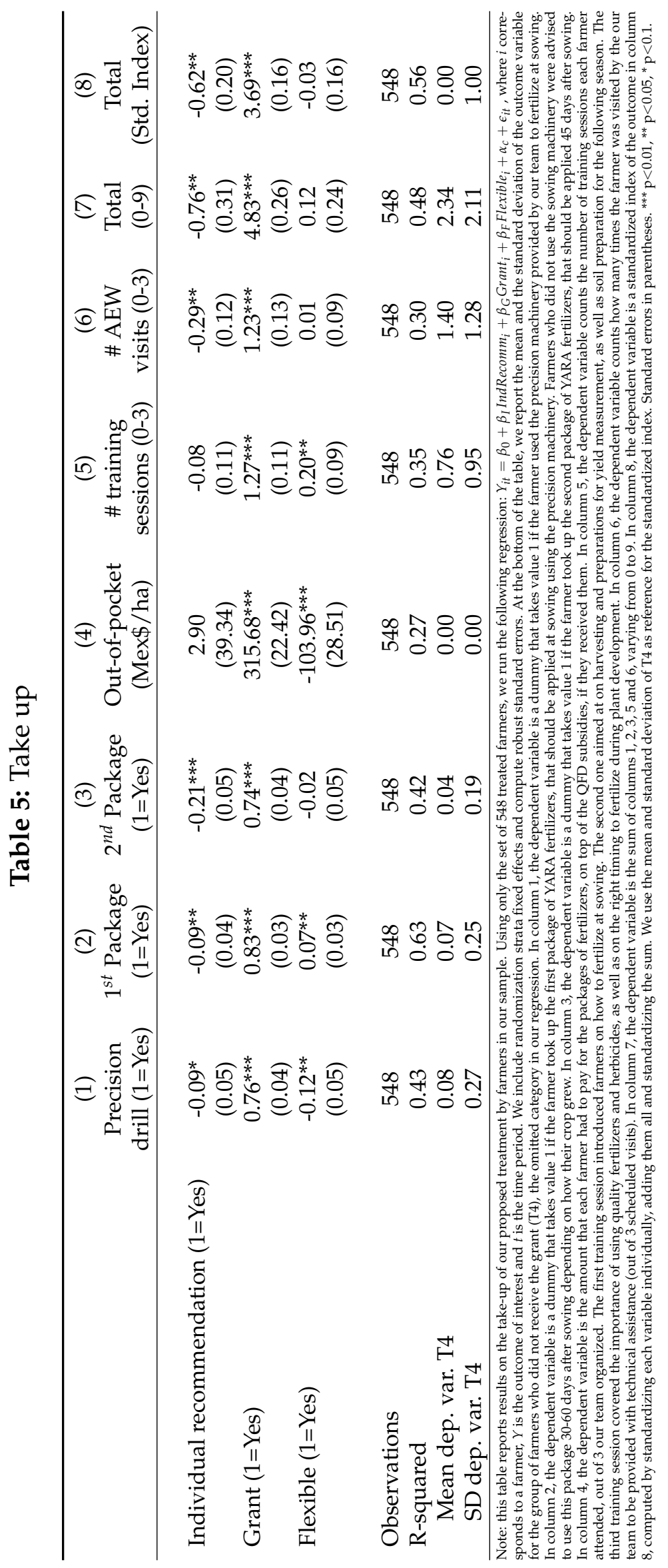


Table 6: Practices 2015

\begin{tabular}{|c|c|c|c|c|}
\hline & \multirow{2}{*}{\multicolumn{2}{|c|}{$\begin{array}{l}(1) \\
\text { Existing practices }\end{array}$}} & \multirow{2}{*}{\multicolumn{2}{|c|}{$\begin{array}{l}(3) \\
\text { All new practices }\end{array}$}} \\
\hline & & & & \\
\hline & $\begin{array}{c}\text { Total practices } \\
\text { applied }\end{array}$ & $\begin{array}{l}\text { Standardized } \\
\text { Index }\end{array}$ & $\begin{array}{c}\text { Total practices } \\
\text { applied }\end{array}$ & $\begin{array}{l}\text { Standardized } \\
\text { Index }\end{array}$ \\
\hline \multirow[t]{2}{*}{ Extension $(1=$ Yes $)$} & 0.04 & 0.06 & $0.35^{* *}$ & $0.33^{* *}$ \\
\hline & $(0.08)$ & $(0.13)$ & $(0.11)$ & $(0.14)$ \\
\hline \multirow[t]{2}{*}{ Individual recommendation $(1=$ Yes $)$} & 0.03 & 0.05 & $-0.33^{* *}$ & $-0.28^{*}$ \\
\hline & $(0.07)$ & $(0.09)$ & $(0.14)$ & $(0.16)$ \\
\hline \multirow[t]{2}{*}{ Grant (1=Yes) } & 0.04 & 0.12 & $2.21^{* * *}$ & $1.63^{* * *}$ \\
\hline & $(0.08)$ & $(0.11)$ & $(0.14)$ & $(0.16)$ \\
\hline \multirow{2}{*}{ Flexible (1=Yes) } & -0.01 & -0.01 & -0.07 & -0.05 \\
\hline & $(0.07)$ & $(0.08)$ & $(0.14)$ & $(0.18)$ \\
\hline Observations & 678 & 678 & 678 & 678 \\
\hline R-squared & 0.07 & 0.07 & 0.55 & 0.34 \\
\hline Mean dep. var. control & 2.38 & 0.00 & 0.32 & 0.00 \\
\hline SD dep. var. control & 0.61 & 1.00 & 0.69 & 1.00 \\
\hline $\mathrm{T} 1: \beta_{E}+\beta_{I}+\beta_{G}=0$ & 0.11 & 0.03 & 0.00 & 0.00 \\
\hline $\mathrm{T} 2: \beta_{E}+\beta_{G}=0$ & 0.25 & 0.09 & 0.00 & 0.00 \\
\hline T3: $\beta_{E}+\beta_{G}+\beta_{F}=0$ & 0.32 & 0.09 & 0.00 & 0.00 \\
\hline \multicolumn{5}{|c|}{  } \\
\hline
\end{tabular}




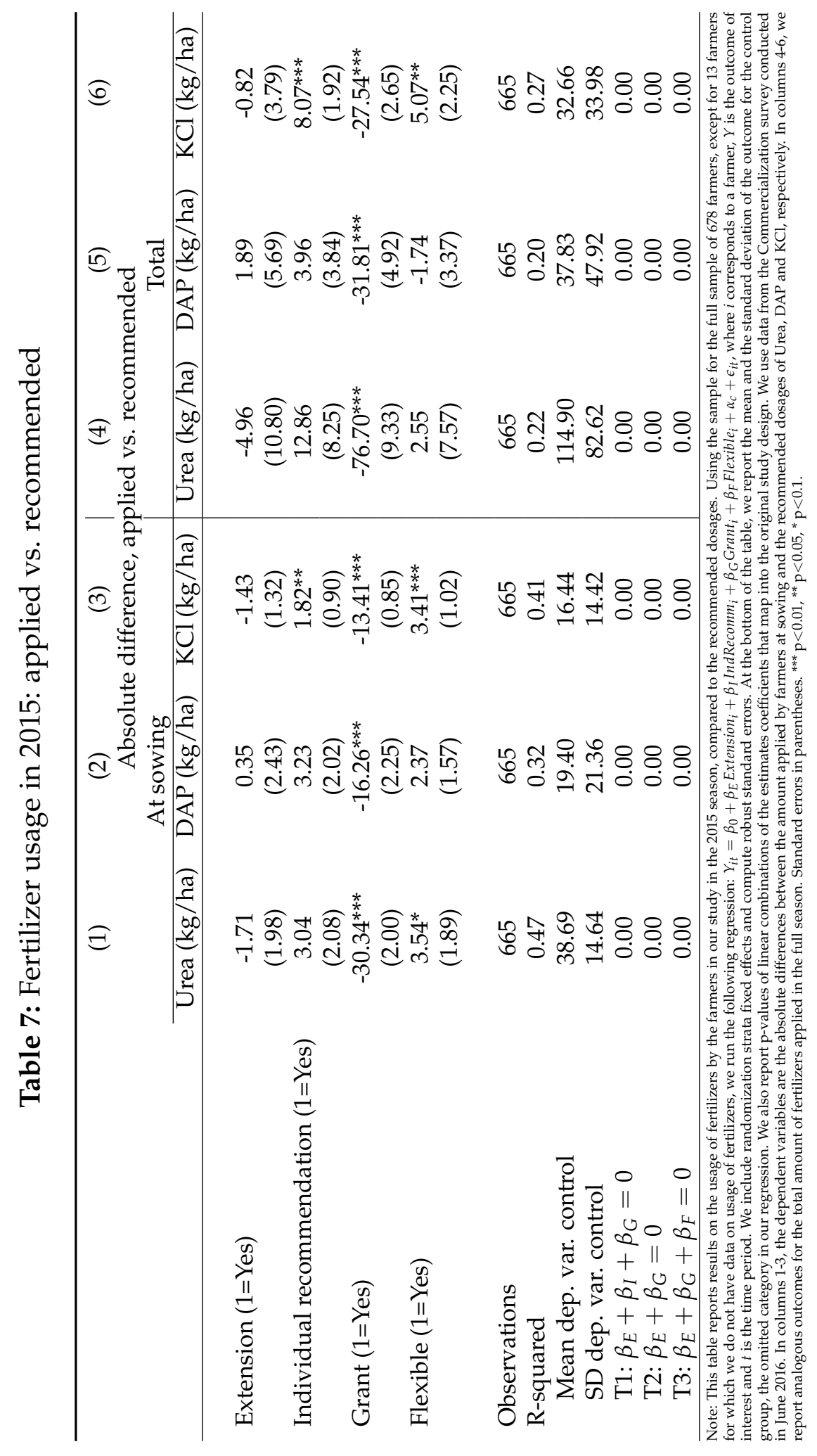




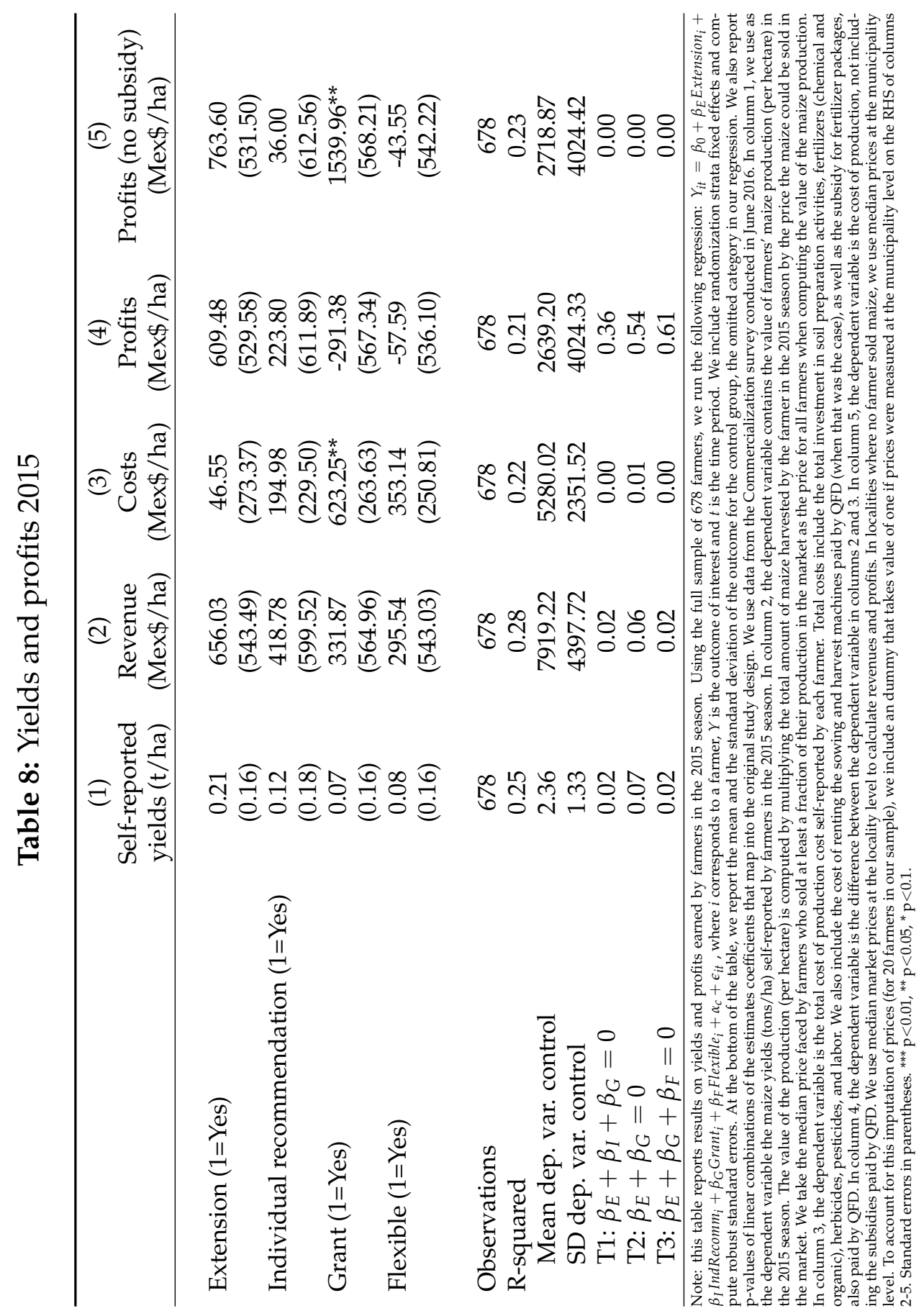


Table 9: Practices 2017

\begin{tabular}{|c|c|c|c|c|}
\hline & \multicolumn{2}{|c|}{$\begin{array}{cc}(1) & (2) \\
\text { Existing practices } 2017\end{array}$} & \multicolumn{2}{|c|}{$(3)$} \\
\hline & $\begin{array}{l}\text { Total practices } \\
\text { applied }\end{array}$ & $\begin{array}{l}\text { Standardized } \\
\text { Index }\end{array}$ & $\begin{array}{l}\text { Total practices } \\
\text { applied }\end{array}$ & $\begin{array}{l}\text { Standardized } \\
\text { Index }\end{array}$ \\
\hline \multirow[t]{2}{*}{ Extension $(1=$ Yes $)$} & 0.10 & 0.11 & $0.24^{* *}$ & $0.39^{* *}$ \\
\hline & $(0.10)$ & $(0.12)$ & $(0.11)$ & $(0.16)$ \\
\hline \multirow{2}{*}{ Individual recommendation ( $1=$ Yes) } & 0.15 & 0.13 & 0.13 & 0.09 \\
\hline & $(0.11)$ & $(0.12)$ & $(0.13)$ & $(0.19)$ \\
\hline \multirow{2}{*}{ Grant (1=Yes) } & $-0.21^{* *}$ & $-0.20^{*}$ & 0.09 & 0.14 \\
\hline & $(0.10)$ & (0.11) & (0.13) & (0.19) \\
\hline \multirow{2}{*}{ Flexible (1=Yes) } & 0.05 & 0.05 & $0.45^{* *}$ & $0.55^{* *}$ \\
\hline & $(0.10)$ & $(0.12)$ & $(0.14)$ & $(0.19)$ \\
\hline Observations & 678 & 678 & 678 & 678 \\
\hline R-squared & 0.07 & 0.05 & 0.20 & 0.17 \\
\hline Mean dep. var. control & 2.31 & 0.00 & 0.42 & 0.00 \\
\hline SD dep. var. control & 0.89 & 1.00 & 0.79 & 1.00 \\
\hline $\mathrm{T} 1: \beta_{E}+\beta_{I}+\beta_{G}=0$ & 0.69 & 0.69 & 0.00 & 0.00 \\
\hline $\mathrm{T} 2: \beta_{E}+\beta_{G}=0$ & 0.34 & 0.50 & 0.00 & 0.00 \\
\hline T3: $\beta_{E}+\beta_{G}+\beta_{F}=0$ & 0.59 & 0.76 & 0.00 & 0.00 \\
\hline \multicolumn{5}{|c|}{  } \\
\hline
\end{tabular}




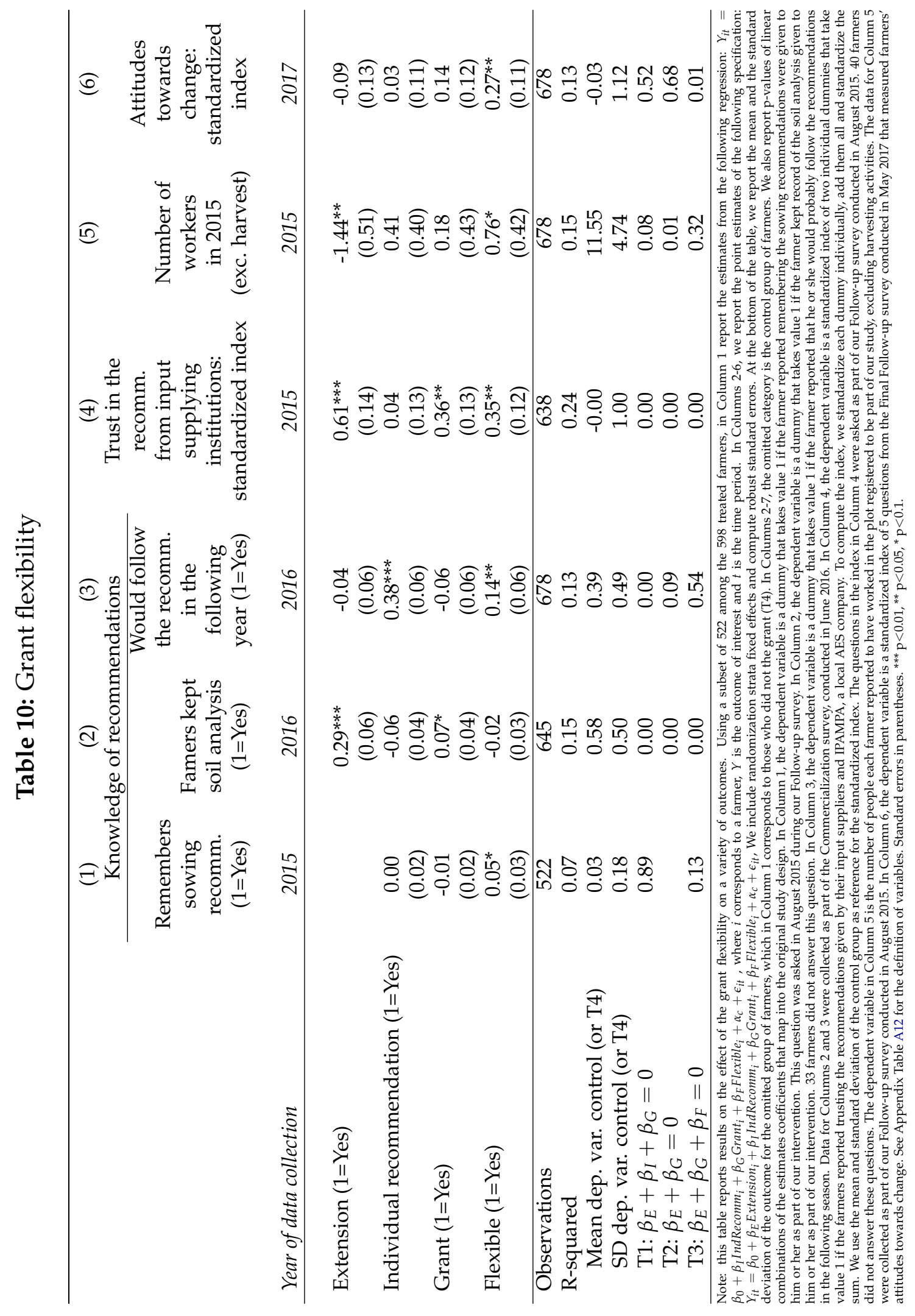


Table 11: WTP for fertilizers

\begin{tabular}{|c|c|c|c|c|}
\hline & \multirow{3}{*}{$\begin{array}{c}(1) \\
\text { Reported WTP for } \\
\text { YARA fertilizers } \\
(1=\text { Yes })\end{array}$} & \multirow{2}{*}{\multicolumn{3}{|c|}{$\begin{array}{l}(2) \\
\text { WTP for a bag of YARA } \\
\text { fertilizer in } 2017 \text { (MeX\$) }\end{array}$}} \\
\hline & & & & \\
\hline & & Urea & DAP & $\mathrm{KCl}$ \\
\hline \multirow[t]{2}{*}{ Extension $(1=$ Yes $)$} & $0.20^{* * *}$ & $71.40^{* * *}$ & $64.91^{* *}$ & $53.11^{* *}$ \\
\hline & $(0.06)$ & $(19.58)$ & $(24.52)$ & (20.58) \\
\hline \multirow[t]{2}{*}{ Individual recommendation ( $1=$ Yes) } & -0.05 & -15.16 & -11.49 & -10.82 \\
\hline & $(0.04)$ & (14.92) & (19.60) & $(18.62)$ \\
\hline \multirow[t]{2}{*}{ Grant (1=Yes) } & $0.36^{* * *}$ & $111.20^{* * *}$ & $139.15^{* * *}$ & $110.29^{* * *}$ \\
\hline & $(0.05)$ & (17.68) & $(22.54)$ & $(20.23)$ \\
\hline \multirow[t]{2}{*}{ Flexible (1=Yes) } & 0.04 & 13.75 & 24.86 & $46.21^{* *}$ \\
\hline & $(0.03)$ & $(13.71)$ & $(18.49)$ & $(17.47)$ \\
\hline Observations & 678 & 678 & 678 & 678 \\
\hline R-squared & 0.33 & 0.28 & 0.24 & 0.25 \\
\hline Mean dep. var. control (or T4) & 0.33 & 100.38 & 121.73 & 98.46 \\
\hline SD dep. var. control (or T4) & 0.47 & 151.12 & 185.92 & 157.18 \\
\hline $\mathrm{T} 1: \beta_{E}+\beta_{I}+\beta_{G}=0$ & 0.00 & 0.00 & 0.00 & 0.00 \\
\hline $\mathrm{T} 2: \beta_{E}+\beta_{G}=0$ & 0.00 & 0.00 & 0.00 & 0.00 \\
\hline $\mathrm{T} 3: \beta_{E}+\beta_{G}+\beta_{F}=0$ & 0.00 & 0.00 & 0.00 & 0.00 \\
\hline \multicolumn{5}{|c|}{$\begin{array}{l}\text { Note: this table reports results willingness to pay for YARA fertilizers. Using the full sample of } 678 \text { farmers in our study, we report the point estimates of the } \\
\text { following specification } \\
\text { interest }\end{array}$} \\
\hline
\end{tabular}




\section{Appendix Tables}

\section{A. Appendix Tables}

Table A1: Analysis of variation: soil characteristics and recommended nutrient dosages

\begin{tabular}{|c|c|c|c|}
\hline & $\begin{array}{c}(1) \\
\frac{\sigma_{\epsilon}}{\sigma_{\alpha}+\sigma_{\epsilon}} \\
\end{array}$ & $\begin{array}{l}(2) \\
\sigma_{\epsilon}\end{array}$ & $\begin{array}{l}(3) \\
\sigma_{\alpha}\end{array}$ \\
\hline \multicolumn{4}{|c|}{ Panel A: Variation in Soil Quality } \\
\hline Sand (\%) & 0.41 & 7.85 & 6.60 \\
\hline Clay (\%) & 0.31 & 4.65 & 3.12 \\
\hline Silt (\%) & 0.38 & 4.72 & 3.71 \\
\hline $\mathrm{pH}(1: 2)$ & 0.36 & 0.53 & 0.40 \\
\hline Nitrogen $(\mathrm{N})$ & 0.11 & 6.75 & 2.32 \\
\hline Phosphorus (P) & 0.21 & 19.52 & 9.94 \\
\hline Potassium $(\mathrm{K})$ & 0.20 & 103.65 & 52.44 \\
\hline \multicolumn{4}{|c|}{ Panel B: Variation in recommended nutrient dosages } \\
\hline Nitrogen (N) & 0.10 & 15.36 & 5.13 \\
\hline Phosphorus (P) & 0.18 & 11.53 & 5.45 \\
\hline Potassium (K) & 0.22 & 14.92 & 7.98 \\
\hline \multicolumn{4}{|c|}{$\begin{array}{l}\text { Note: This table reports heterogeneity between and across Mexican localities in soil } \\
\text { characteristics and recommended nutrient dosages for the study sample of } 678 \text { farm- } \\
\text { ers. We run a standard analysis of variance (ANOVA) for each of the soil charac- } \\
\text { teristics and we report estimates of variation within }\left(\sigma_{\epsilon}\right) \text { and across locaities }\left(\sigma_{\alpha}\right) \text { in } \\
\text { Columns } 2 \text { and } 3 \text {, as well as the share of the total variation arising from between clus- } \\
\text { ter variation in Column } 1 \text {. Panel reports numbers for soil characteristics measured at } \\
\text { baseline and in Panel } \mathrm{B} \text { we report number for the recommended dosage of three of } \\
\text { the main nutrients provided by inorganic fertilizers. }\end{array}$} \\
\hline
\end{tabular}


Table A2: Sample attrition

\begin{tabular}{|c|c|c|}
\hline & $\begin{array}{c}(1) \\
\text { Main } \\
\text { sample }\end{array}$ & $\begin{array}{c}(2) \\
\text { Yield measured with } \\
\text { harvester }(1=\text { Yes })\end{array}$ \\
\hline Extension (1=Yes) & $\begin{array}{l}-0.00 \\
(0.05)\end{array}$ & $\begin{array}{l}-0.02 \\
(0.06)\end{array}$ \\
\hline Individual recommendation ( $1=$ Yes) & $\begin{array}{c}0.01 \\
(0.04)\end{array}$ & $\begin{array}{l}-0.09^{*} \\
(0.05)\end{array}$ \\
\hline Grant (1=Yes) & $\begin{array}{c}0.03 \\
(0.05)\end{array}$ & $\begin{array}{c}0.24^{* * *} \\
(0.05)\end{array}$ \\
\hline Flexible (1=Yes) & $\begin{array}{c}0.03 \\
(0.04)\end{array}$ & $\begin{array}{c}-0.06 \\
(0.05)\end{array}$ \\
\hline Observations & 981 & 678 \\
\hline R-squared & 0.11 & 0.11 \\
\hline Mean dep. var. control & 0.67 & 0.63 \\
\hline SD dep. var. control & 0.47 & 0.48 \\
\hline $\mathrm{T} 1: \beta_{E}+\beta_{I}+\beta_{G}=0$ & 0.30 & 0.02 \\
\hline $\mathrm{T} 2: \beta_{E}+\beta_{G}=0$ & 0.47 & 0.00 \\
\hline T3: $\beta_{E}+\beta_{G}+\beta_{F}=0$ & 0.15 & 0.00 \\
\hline \multicolumn{3}{|c|}{ 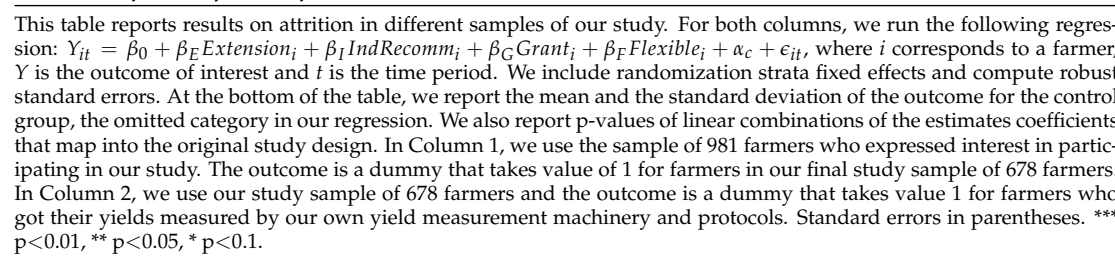 } \\
\hline
\end{tabular}


Table A3: Control practices in 2014 and 2015

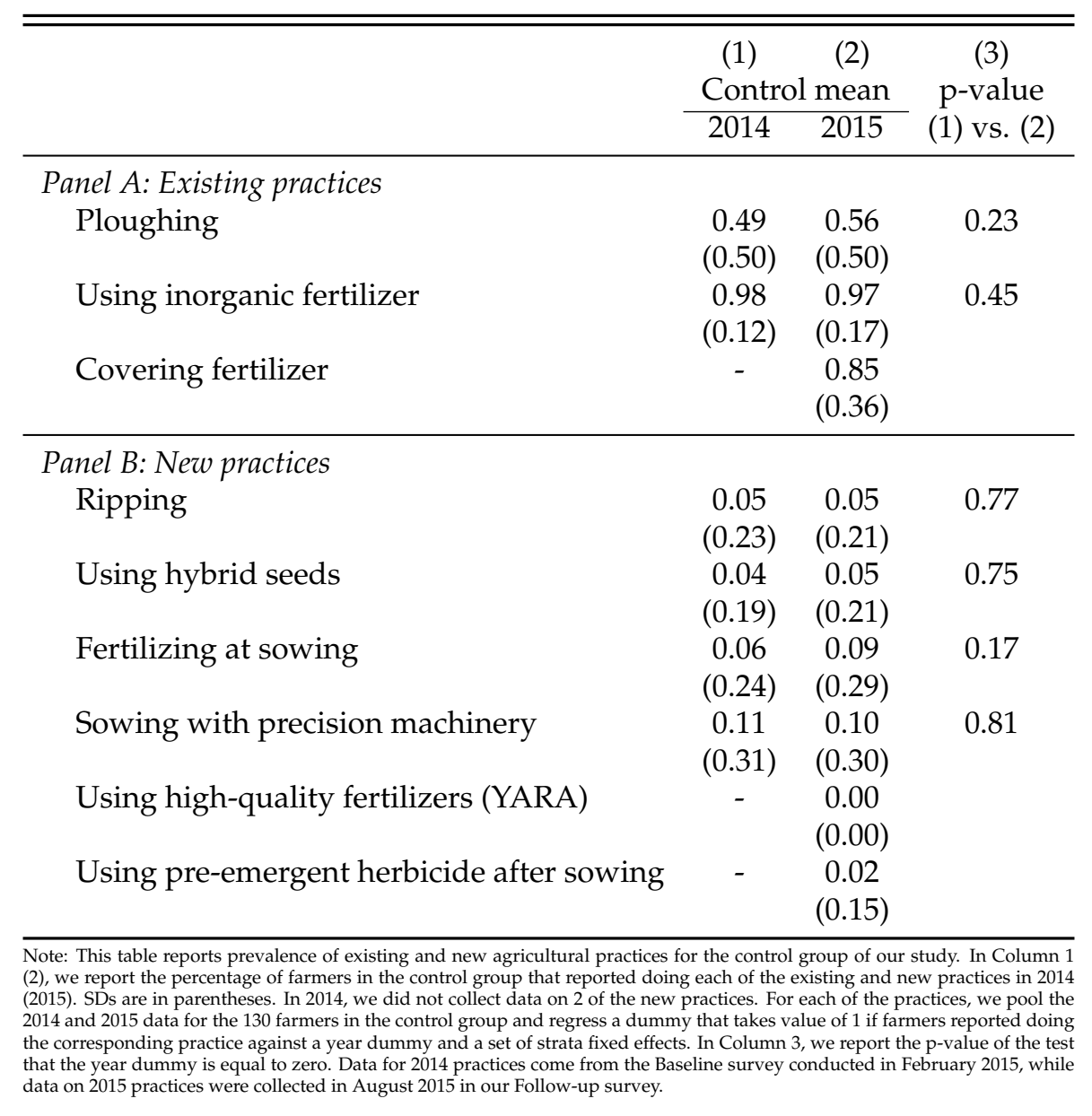


Table A4: Comparing Study Sample to Mexican Farmers

\begin{tabular}{|c|c|c|c|c|c|c|}
\hline & \multicolumn{2}{|c|}{ Mexico } & \multicolumn{2}{|c|}{ Tlaxcala } & \multicolumn{2}{|c|}{ Study Sample } \\
\hline & Mean & S.D. & Mean & S.D. & Mean & S.D. \\
\hline \multicolumn{7}{|l|}{ Panel A: All plots } \\
\hline Plot is rain fed ( $1=$ Yes $)$ & 0.88 & 0.21 & 0.95 & 0.08 & 0.96 & 0.19 \\
\hline Plot owner uses inorganic fertilizers ( $1=$ Yes) & 0.74 & 0.28 & 0.88 & 0.11 & 0.97 & 0.16 \\
\hline Plot owner uses organic fertilizers ( $1=$ Yes) & 0.20 & 0.21 & 0.31 & 0.20 & 0.41 & 0.49 \\
\hline Plot owner uses hybrid seeds ( $1=$ Yes) & 0.24 & 0.26 & 0.08 & 0.09 & 0.07 & 0.25 \\
\hline Plot owner uses herbicides ( $1=$ Yes) & 0.35 & 0.30 & 0.38 & 0.31 & 0.73 & 0.44 \\
\hline Plot owner uses insecticides ( $1=$ Yes) & 0.21 & 0.24 & 0.12 & 0.12 & 0.13 & 0.33 \\
\hline Plot owner has access to extension services ( $1=$ Yes) & 0.03 & 0.06 & 0.01 & 0.01 & 0.10 & 0.31 \\
\hline Maize yields (ton/ha) & 2.73 & 2.50 & 2.67 & 1.66 & 2.01 & 1.13 \\
\hline \multicolumn{7}{|l|}{ Panel B: Rain-fed plots } \\
\hline Plot owner uses inorganic fertilizers ( $1=$ Yes) & 0.75 & 0.30 & 0.96 & 0.08 & 0.97 & 0.16 \\
\hline Plot owner uses organic fertilizers ( $1=$ Yes $)$ & 0.18 & 0.23 & 0.13 & 0.13 & 0.41 & 0.49 \\
\hline Plot owner uses hybrid seeds (1=Yes) & 0.11 & 0.19 & 0.06 & 0.06 & 0.06 & 0.23 \\
\hline Plot owner uses herbicides (1=Yes) & 0.26 & 0.32 & 0.68 & 0.38 & 0.74 & 0.44 \\
\hline Plot owner uses insecticides ( $1=$ Yes) & 0.12 & 0.21 & 0.13 & 0.15 & 0.13 & 0.33 \\
\hline Plot owner has access to extension services ( $1=$ Yes) & 0.03 & 0.06 & 0.05 & 0.06 & 0.10 & 0.30 \\
\hline
\end{tabular}

Table A5: Lab analysis of nutrient content of YARA and government fertilizers

\begin{tabular}{|c|c|c|c|c|c|}
\hline & (1) & (2) & (3) & (4) & (5) \\
\hline & & \multicolumn{2}{|c|}{ Government } & \multicolumn{2}{|r|}{ YARA } \\
\hline & $\begin{array}{c}\text { Label } \\
(\%)\end{array}$ & $\begin{array}{c}\text { Lab test } \\
(\%)\end{array}$ & $\begin{array}{c}\text { Cost per kg of } \\
\text { nutrient }(\text { Mex\$) }\end{array}$ & $\begin{array}{c}\text { Lab test } \\
(\%)\end{array}$ & $\begin{array}{l}\text { Cost per kg of } \\
\text { nutrient }(\operatorname{Mex} \$)\end{array}$ \\
\hline \multicolumn{6}{|l|}{ Panel A: Urea } \\
\hline Nitrogen $(\mathrm{N})$ & 46 & 46.73 & 13.02 & 47.00 & 13.62 \\
\hline Phosphorus $(\mathrm{P})$ & 0 & 0.00 & . & 0.00 & . \\
\hline Potassium $(\mathrm{K})$ & 0 & 0.00 & . & 0.00 & . \\
\hline Cost of 50kg bag (Mex\$) & & \multicolumn{2}{|r|}{304} & \multicolumn{2}{|r|}{320} \\
\hline \multicolumn{6}{|l|}{ Panel B: DAP } \\
\hline Nitrogen $(\mathrm{N})$ & 18 & 10.40 & 82.69 & 16.70 & 55.09 \\
\hline Phosphorus (P) & 46 & 14.00 & 61.43 & 36.20 & 25.41 \\
\hline Potassium (K) & 0 & 0.00 & . & 0.00 & . \\
\hline Cost of $50 \mathrm{~kg}$ bag (Mex\$) & & \multicolumn{2}{|r|}{430} & \multicolumn{2}{|r|}{460} \\
\hline \multicolumn{6}{|l|}{ Panel C: $\mathrm{KCl}$} \\
\hline Nitrogen $(\mathrm{N})$ & 0 & 0.00 & . & 0.00 & . \\
\hline Phosphorus (P) & 0 & 0.00 & . & 0.00 & . \\
\hline Potassium (K) & 60 & 51.23 & 12.26 & 53.10 & 15.82 \\
\hline Cost of $50 \mathrm{~kg}$ bag (Mex\$) & & \multicolumn{2}{|r|}{314} & \multicolumn{2}{|r|}{420} \\
\hline
\end{tabular}







Table A7: Measured yields 2015

\begin{tabular}{|c|c|c|}
\hline & $\begin{array}{c}\text { (1) } \\
\text { Measured } \\
\text { yields } \\
\text { (t/ha) }\end{array}$ & $\begin{array}{c}(2) \\
\text { Self-reported } \\
\text { yields (t/ha) } \\
\text { (Measurement } \\
\text { sample) }\end{array}$ \\
\hline Extension $(1=$ Yes $)$ & $\begin{array}{l}0.38^{*} \\
(0.20)\end{array}$ & $\begin{array}{l}0.36^{*} \\
(0.21)\end{array}$ \\
\hline Individual recommendation (1=Yes) & $\begin{array}{c}0.16 \\
(0.18)\end{array}$ & $\begin{array}{c}0.03 \\
(0.18)\end{array}$ \\
\hline Grant (1=Yes) & $\begin{array}{c}-0.14 \\
(0.21)\end{array}$ & $\begin{array}{l}-0.13 \\
(0.21)\end{array}$ \\
\hline Flexible (1=Yes) & $\begin{array}{c}0.19 \\
(0.18)\end{array}$ & $\begin{array}{c}0.10 \\
(0.18)\end{array}$ \\
\hline Observations & 498 & 498 \\
\hline R-squared & 0.29 & 0.27 \\
\hline Mean dep. var. control & 2.41 & 2.30 \\
\hline SD dep. var. control & 1.30 & 1.41 \\
\hline $\mathrm{T} 1: \beta_{E}+\beta_{I}+\beta_{G}=0$ & 0.03 & 0.16 \\
\hline $\mathrm{T} 2: \beta_{E}+\beta_{G}=0$ & 0.18 & 0.23 \\
\hline T3: $\beta_{E}+\beta_{G}+\beta_{F}=0$ & 0.02 & 0.09 \\
\hline \multicolumn{3}{|c|}{ 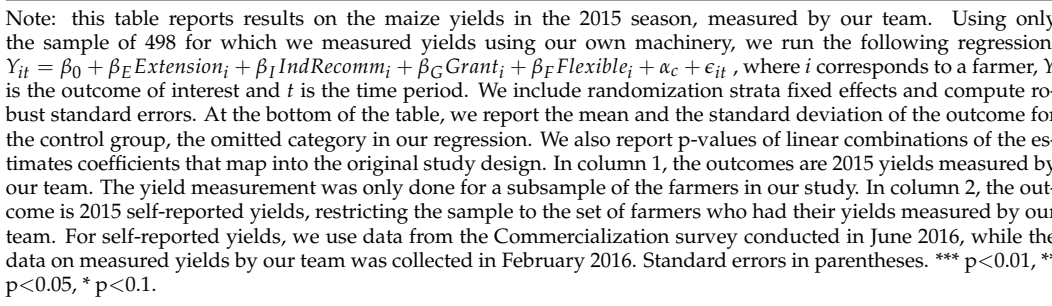 } \\
\hline
\end{tabular}

Table A8: Drought throughout the years

\begin{tabular}{lccccccc}
\hline \hline & \multicolumn{2}{c}{$(1)$} & $(2)$ & $(3)$ & $(4)$ & $(5)$ & $(6)$ \\
& \multicolumn{2}{c}{2014} & \multicolumn{2}{c}{2015} & \multicolumn{2}{c}{2016} \\
\cline { 2 - 8 } & Mean & p-value & Mean & p-value & Mean & p-value \\
\hline Precipitation at initial stage (mm) & 77.51 & 0.87 & 77.32 & 0.75 & 64.23 & 0.05 \\
& $(38.58)$ & & $(35.57)$ & & $(39.41)$ & \\
Total precipitation (mm) & 698.87 & 0.75 & 599.14 & 0.53 & 658.56 & 0.84 \\
& $(120.95)$ & & $(75.06)$ & & $(59.48)$ & \\
Suffered drought (1=Yes) & - & 0.84 & 0.73 & 0.24 & 0.32 & 0.55 \\
& & & $(0.44)$ & & $(0.47)$ & \\
\hline
\end{tabular}

Note: this table shows precipitation measures and drought reports by farmers during the time of our study. For the 2014, 2015 and 2016 seasons, we report the average precipitation (in $\mathrm{mm}$ ) during the 30 days following sowing and average precipitation (in $\mathrm{mm}$ ) faced by each farmer during the whole season. For each farmer, the precipitation figures are measured by the closest station to the registered plot. Data is provided by CONAGUA. For the 2015 and 2016, we also report the share of farmers who reported facing a drought at some point in the season. Data for these reports come from the Baseline and Commercialization surveys. Columns 1, 3 and 5 show means and standard deviations of each variable for the 2014, 2015 and 2016 seasons, respectively, for our full sample. For each season, we take each variable and regress it against the set of treatment dummies. In columns 2, 4 and 6, we report the p-values of the F-tests that the dummy coefficients are all equal. 
Table A9: Expected yields 2015

\begin{tabular}{|c|c|}
\hline & $\begin{array}{l}\text { Change in Expected Yields (t/ha) } \\
\text { between July and November } 2015\end{array}$ \\
\hline Reported drought in 2015 (1=Yes) & $\begin{array}{l}-0.17^{*} \\
(0.09)\end{array}$ \\
\hline Observations & 638 \\
\hline R-squared & 0.12 \\
\hline Mean dep. var. control & -0.03 \\
\hline SD dep. var. control & 1.00 \\
\hline Lee Bounds & {$[-0.24,-0.13]$} \\
\hline \multicolumn{2}{|c|}{ 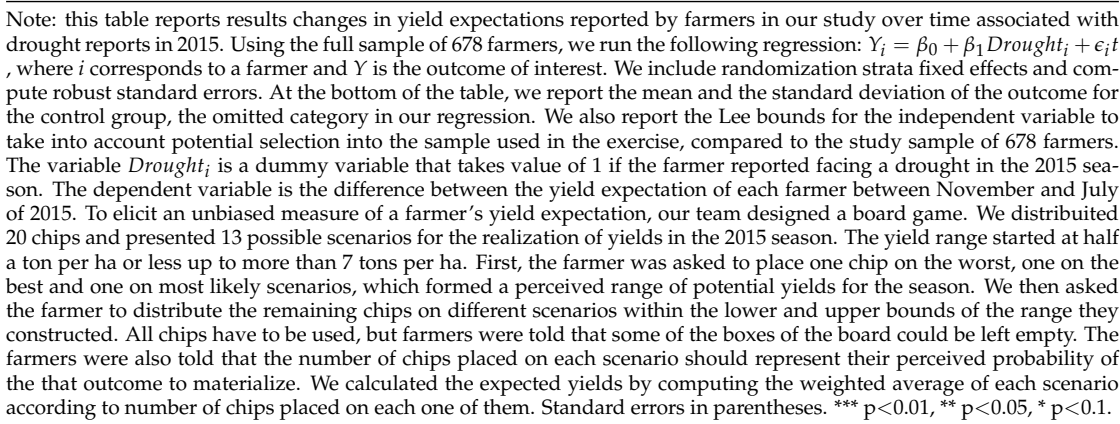 } \\
\hline
\end{tabular}

Table A10: Cost disaggregation 2015

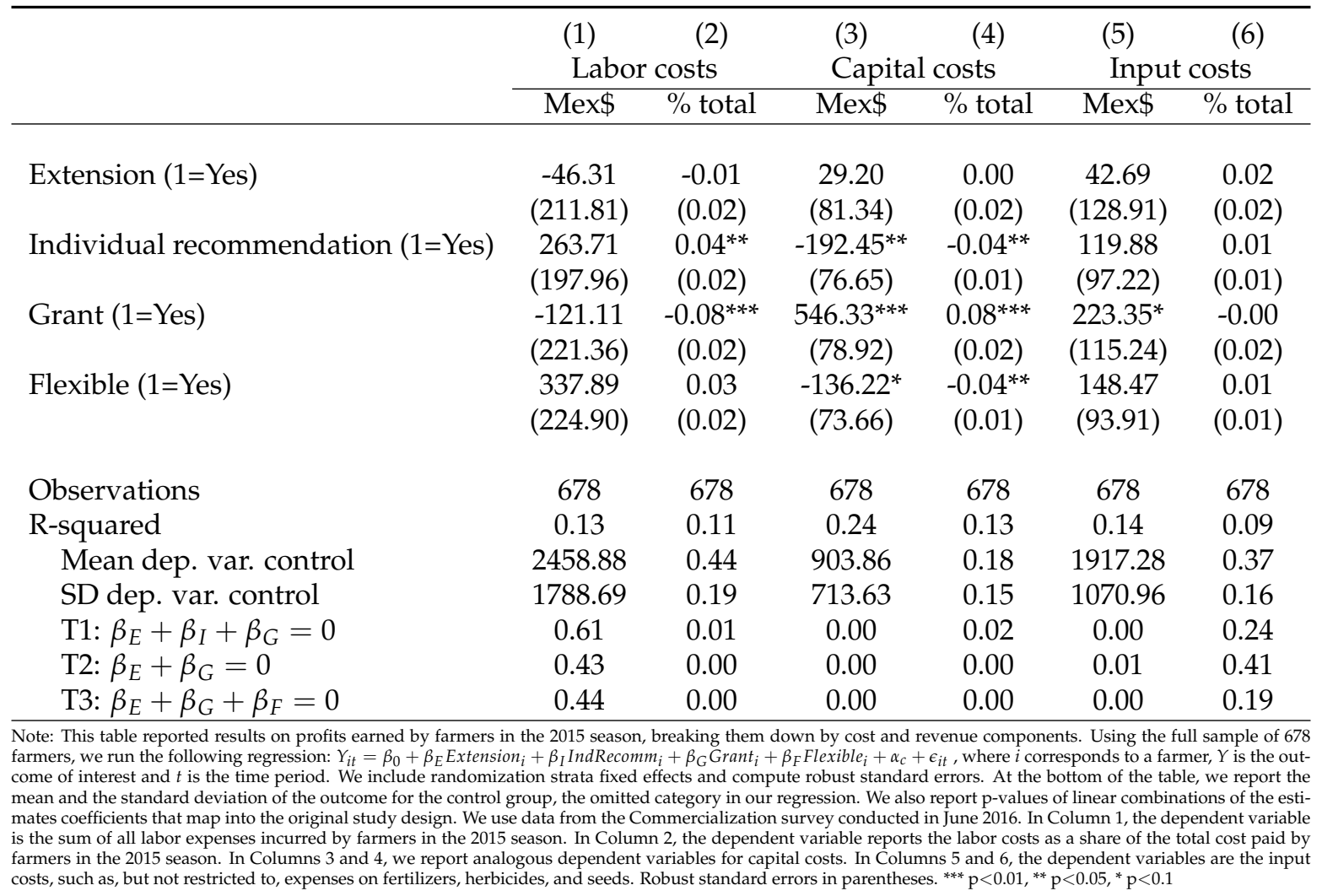




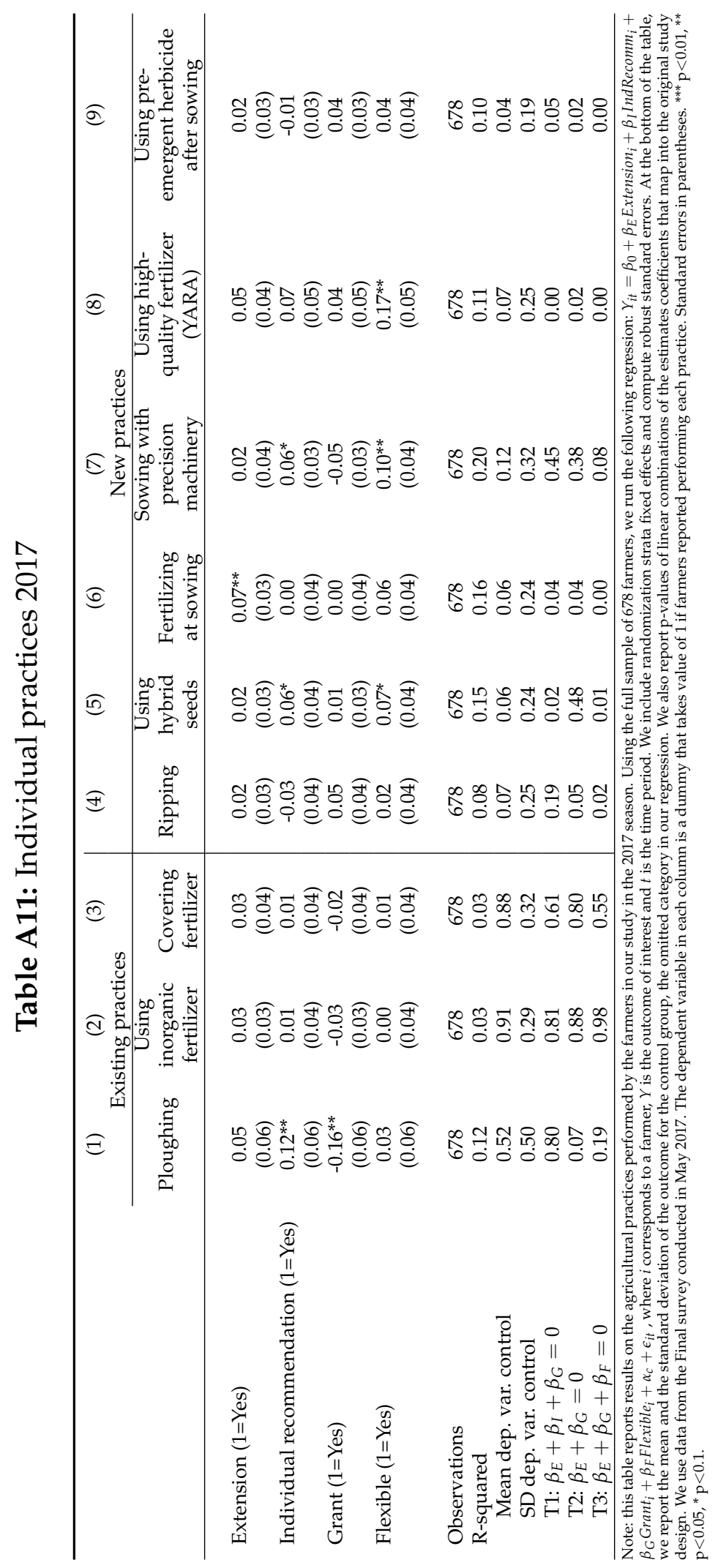




\section{Table A12: Definition of variables}

\begin{tabular}{|c|c|}
\hline Variable & Definition \\
\hline \multicolumn{2}{|l|}{ Panel A: Farmers characteristics } \\
\hline $\begin{array}{l}\text { Annual income in } 2014 \\
\text { (000s pesos) }\end{array}$ & $\begin{array}{l}\text { Total income earned by farmer in 2014, including, but restricted to, sales from agricultural activities, labor } \\
\text { earning in agricultural and non-agricultural activities, sales of animals, remmitances, pensions and cash } \\
\text { transfers. Collected using our Baseline survey conducted in February } 2015 \text {. }\end{array}$ \\
\hline $\begin{array}{l}\text { Reported liquidity con- } \\
\text { straints }(1=\text { Yes })\end{array}$ & $\begin{array}{l}\text { Dummy that takes value } 1 \text { if farmer reported above-average amount when asked the following question: } \\
\text { "How much money per hectare were you missing in order to sow the way you would have wanted?". Col- } \\
\text { lected using our Baseline survey conducted in February } 2015 \text {. }\end{array}$ \\
\hline $\begin{array}{l}\text { Ever applied for a loan } \\
(1=\text { Yes })\end{array}$ & $\begin{array}{l}\text { Dummy that takes value } 1 \text { if farmer answered "Yes" to the following question: "Have you ever, in your entire } \\
\text { life, applied for credit or a loan for matters related to agriculture?". Collected using our Baseline survey } \\
\text { conducted in February } 2015 \text {. }\end{array}$ \\
\hline Never takes risks $(1=$ Yes $)$ & $\begin{array}{l}\text { Dummy that takes value of } 1 \text { if farmer selected the first option when asked the question "Do you consider } \\
\text { yourself a risk taker? You would say:" and given the following options: "1. Does not like taking risks", "2. } \\
\text { Almost never take risks", "3. Sometimes yes, sometimes no", "4. Almost always takes risks", "5. Always likes } \\
\text { to take risks". Collected using our Baseline survey conducted in February } 2015 \text {. }\end{array}$ \\
\hline \multicolumn{2}{|l|}{ Panel B: 2014 Practices \& Yields } \\
\hline Number of plots cultivated & $\begin{array}{l}\text { Number of plots farmers reported working on as owner or tenant in } 2014 \text {. Collected using our Baseline } \\
\text { survey conducted in February } 2015 .\end{array}$ \\
\hline Total area cultivated (ha) & $\begin{array}{l}\text { Number of hectares farmers reported working on as owner or tenant in 2014. Collected using our Baseline } \\
\text { survey conducted in February } 2015 .\end{array}$ \\
\hline $\begin{array}{l}\text { Supported by a govern- } \\
\text { ment program in } 2014 \\
(1=\text { Yes })\end{array}$ & $\begin{array}{l}\text { Dummy that takes value of } 1 \text { if farmers reported being supported by any of the following input subsidy } \\
\text { programs in 2014: PROCAMPO, PIMAF, MASAGRO or Agroincentivos. Collected using our Baseline survey } \\
\text { conducted in February } 2015 \text {. }\end{array}$ \\
\hline \multicolumn{2}{|c|}{ Panel C: Grant flexibility outcomes } \\
\hline $\begin{array}{l}\text { Trust in the recommenda- } \\
\text { tion from input supply- } \\
\text { ing institutions (standard- } \\
\text { ized index) }\end{array}$ & $\begin{array}{l}\text { Standardized index of two individual dummies that take value } 1 \text { if the farmers reported trusting the recom- } \\
\text { mendations given by their input suppliers and IPAMPA, a local AES company. Computed by standardizing } \\
\text { each dummy individually, adding them all and standardizing the sum. We use the mean and standard de- } \\
\text { viation of the control group as reference for the standardized index. Collected in August } 2015 \text { using our } \\
\text { Follow-up survey. } 40 \text { among our sample of } 678 \text { farmers fesued to answer these questions. }\end{array}$ \\
\hline $\begin{array}{l}\text { Attitudes towards change } \\
\text { (standardized index) }\end{array}$ & $\begin{array}{l}\text { Standardized count of affirmative answers to } 3 \text { questions and the answer given to other } 2 \text { on a frequency } \\
\text { scale. The } 3 \text { first questions are: "When you learn about a new farming technique, compared to most of your } \\
\text { neighbours, you: are more willing to try it first" (vs. "[...], you: let others try it first"); "In your plots you } \\
\text { prefer: doing something new" (vs. "[...] you prefer: routine things"); and "Generally you prefer: changing } \\
\text { things" (vs. "[...] leaving things the way they are"). The last } 2 \text { questions are: "You often go to the plots of } \\
\text { fellow farmers to observe what they do" and "You have tried to experiment on your own plot some of the } \\
\text { techniques learned from fellow farmers". Answers to these } 2 \text { last questions were given on the following scale: } \\
\text { "1. Always", "2. Almost always", "3. Sometimes". "4. Almost never" and " } 5 \text {. Never". To get a standardized } \\
\text { index, we subtract from each variable the control mean and divides by the control standard deviation, then } \\
\text { sums the standardized variables and standardizes again with the mean and the standard deviation of the } \\
\text { sum among controls. We use data from the Final survey conducted in May } 2017 \text {. }\end{array}$ \\
\hline \multicolumn{2}{|c|}{ Panel D: Expectation of soil quality } \\
\hline Quality (0-10) & $\begin{array}{l}\text { Answer given by farmers to the following question: "In a scale from } 1 \text { to } 10 \text {, where } 10 \text { is the most productive } \\
\text { plot in the town and } 0 \text { is the least productive plot of the town. How productive do you think your plot } \\
\text { is?". Asked before and after enumerators read the soil analysis report to the farmers in the treatment group. } \\
\text { Collected using our Baseline survey conducted in February } 2015 \text {. }\end{array}$ \\
\hline Very sure? (1=Yes) & $\begin{array}{l}\text { Dummy that takes value } 1 \text { if farmers answered "Absolutely sure" to the following question: "Now I want you } \\
\text { to think about the response to the previous question where you graded your plot with a [Quality (0-10)] for } \\
\text { its productivity. How sure are you about this grade?". The options given to farmers were "Absolutely sure", } \\
\text { "Quite sure", "A bit sure", "Not sure at all". Collected using our Baseline survey conducted in February } 2015 .\end{array}$ \\
\hline
\end{tabular}




\section{B. Appendix tables, T1-T4 specification}

Table B1: Take up (T1-T4 specification)

\begin{tabular}{|c|c|c|c|c|c|c|c|c|}
\hline & $\begin{array}{c}(1) \\
\text { Precision } \\
\text { drill }(1=Y e s)\end{array}$ & $\begin{array}{c}(2) \\
1^{\text {st }} \text { Package } \\
(1=\text { Yes })\end{array}$ & $\begin{array}{c}(3) \\
2^{\text {nd }} \text { Package } \\
(1=Y e s)\end{array}$ & $\begin{array}{c}(4) \\
\text { Out-of-pocket } \\
\text { (Mex\$/ha) }\end{array}$ & $\begin{array}{c}(5) \\
\# \text { training } \\
\text { sessions }(0-3)\end{array}$ & $\begin{array}{c}(6) \\
\# \text { AEW } \\
\text { visits }(0-3)\end{array}$ & $\begin{array}{c}(7) \\
\text { Total } \\
(0-9)\end{array}$ & $\begin{array}{c}(8) \\
\text { Total } \\
(\text { Std. Index) }\end{array}$ \\
\hline $\mathrm{T} 1$ & $\begin{array}{c}0.68^{* * *} \\
(0.04)\end{array}$ & $\begin{array}{c}0.74^{* * *} \\
(0.04)\end{array}$ & $\begin{array}{c}0.54^{* * *} \\
(0.05)\end{array}$ & $\begin{array}{c}318.58^{* * *} \\
(33.44)\end{array}$ & $\begin{array}{c}1.19^{* * *} \\
(0.12)\end{array}$ & $\begin{array}{c}0.94^{* * *} \\
(0.14)\end{array}$ & $\begin{array}{c}4.08^{* * *} \\
(0.31)\end{array}$ & $\begin{array}{c}3.07^{* * *} \\
(0.18)\end{array}$ \\
\hline $\mathrm{T} 2$ & $\begin{array}{c}0.76^{* * *} \\
(0.04)\end{array}$ & $\begin{array}{c}0.83^{* * *} \\
(0.03)\end{array}$ & $\begin{array}{c}0.74^{* * *} \\
(0.04)\end{array}$ & $\begin{array}{c}315.68^{* * *} \\
(22.42)\end{array}$ & $\begin{array}{c}1.27^{* * *} \\
(0.11)\end{array}$ & $\begin{array}{c}1.23^{* * *} \\
(0.13)\end{array}$ & $\begin{array}{c}4.83^{* * *} \\
(0.26)\end{array}$ & $\begin{array}{c}3.69^{* * *} \\
(0.16)\end{array}$ \\
\hline $\mathrm{T} 3$ & $\begin{array}{c}0.64^{* * *} \\
(0.04)\end{array}$ & $\begin{array}{c}0.89 * * * \\
(0.03)\end{array}$ & $\begin{array}{c}0.72^{* * *} \\
(0.04)\end{array}$ & $\begin{array}{c}211.72^{* * *} \\
(20.27)\end{array}$ & $\begin{array}{c}1.47^{* * *} \\
(0.10)\end{array}$ & $\begin{array}{c}1.23^{* * *} \\
(0.12)\end{array}$ & $\begin{array}{c}4.96^{* * *} \\
(0.23)\end{array}$ & $\begin{array}{c}3.66^{* * *} \\
(0.14)\end{array}$ \\
\hline Observations & 548 & 548 & 548 & 548 & 548 & 548 & 548 & 548 \\
\hline R-squared & 0.43 & 0.63 & 0.42 & 0.27 & 0.35 & 0.30 & 0.48 & 0.56 \\
\hline Mean dep. var. T4 & 0.08 & 0.07 & 0.04 & 0.00 & 0.76 & 1.40 & 2.34 & 0.00 \\
\hline SD dep. var. T4 & 0.27 & 0.25 & 0.19 & 0.00 & 0.95 & 1.28 & 2.11 & 1.00 \\
\hline
\end{tabular}

Note: this table reports results on the take-up of our proposed treatment by farmers in our sample. Using only the set of 548 treated farmers, we run the following regression: $Y_{i t}=\beta_{0}+\beta_{1} T 1_{i}+\beta_{2} T 2_{i}+\beta_{3} T 3+\alpha_{c}+\epsilon_{i t}$, where $i$ corresponds to a farmer, $Y$ is the outcome of interest and $t$ is the time period. We include randomization strata fixed effects and compute robust standard errors. At the bottom of the table, we report the mean and the standard deviation of the outcome variable for the group of farmers who did not receive the grant (T4), the omitted category in our regression. In column 1, the dependent variable is a dummy that takes value 1 if the farmer used the
precision machinery provided by our team to fertilize at sowing. In column 2, the dependent variable is a dummy that takes value 1 if the farmer took up the first package of YARA fertilizers, that should be applied at sowing using precision machinery provided by our team to fertilize at sowing. In column 2, the dependent variable is a dummy that takes value 1 if the farmer took up the first package of YARA fertilizers, that should be applied at sowning using
the precision machinery. Farmers who did not use the sowing machinery were advised to use this package $30-60$ days after sowing depending on how their crop grew. In column 3 , the dependent variable is a dummy that takes of the OFD subsidies, if they received them. In column 5 , the dependent variable counts the number of training sessions each farmer attended, out of 3 our team organized. The first training session introduced farmers on how to fertilize at sowing. The second one aimed at on harvesting and preparations for yield measurement, as well as soil preparation for the following season. The third training session covered the importance of using quality fertilizers and herbicides, as well as on the right timing to fertilize during plant development. In column 6 , the dependent variable counts how many times the farmer was visited by the our team to be provided with technical assistance (out of 3 scheduled visits). In column 7 , the dependent variable is the sum of columns $1,2,3,5$ and 6 , varying from 0 to 9 . In column 8 , the dependent variable is a standardized index of the outcome in column 8 , computed by standardizing each variable individually, adding them all and standardizing the sum. We use the mean and standard deviation of $\mathrm{T} 4$ as reference for the standardized index. Standard errors in parentheses. ${ }^{* * *} \mathrm{p}<0.01,{ }^{* *} \mathrm{p}<0.05$, 
Table B2: Practices 2015 (T1-T4 specification)

\begin{tabular}{|c|c|c|c|c|}
\hline & \multirow{2}{*}{\multicolumn{2}{|c|}{$\begin{array}{l}(1) \\
\text { Existing practices }\end{array}$}} & \multirow{2}{*}{\multicolumn{2}{|c|}{$\begin{array}{l}\text { (3) } \\
\text { All new practices }\end{array}$}} \\
\hline & & & & \\
\hline & $\begin{array}{c}\text { Total practices } \\
\text { applied }\end{array}$ & $\begin{array}{l}\text { Standardized } \\
\text { Index }\end{array}$ & $\begin{array}{l}\text { Total practices } \\
\text { applied }\end{array}$ & $\begin{array}{l}\text { Standardized } \\
\text { Index }\end{array}$ \\
\hline \multirow[t]{2}{*}{$\mathrm{T} 1$} & 0.11 & $0.23^{* *}$ & $2.23^{* * *}$ & $1.69^{* * *}$ \\
\hline & $(0.07)$ & $(0.11)$ & $(0.12)$ & $(0.13)$ \\
\hline \multirow[t]{2}{*}{$\mathrm{T} 2$} & 0.08 & $0.18^{*}$ & $2.56^{* * *}$ & $1.96^{* * *}$ \\
\hline & $(0.07)$ & $(0.11)$ & $(0.11)$ & $(0.14)$ \\
\hline \multirow[t]{2}{*}{ T3 } & 0.07 & $0.18^{*}$ & $2.50^{* * *}$ & $1.91^{* * *}$ \\
\hline & (0.07) & (0.10) & $(0.11)$ & $(0.16)$ \\
\hline \multirow[t]{2}{*}{$\mathrm{T} 4$} & 0.04 & 0.06 & $0.35^{* *}$ & $0.33^{* *}$ \\
\hline & $(0.08)$ & $(0.13)$ & $(0.11)$ & $(0.14)$ \\
\hline Observations & 678 & 678 & 678 & 678 \\
\hline R-squared & 0.07 & 0.07 & 0.55 & 0.34 \\
\hline Mean dep. var. control & 2.38 & 0.00 & 0.32 & 0.00 \\
\hline SD dep. var. control & 0.61 & 1.00 & 0.69 & 1.00 \\
\hline \multicolumn{5}{|c|}{ 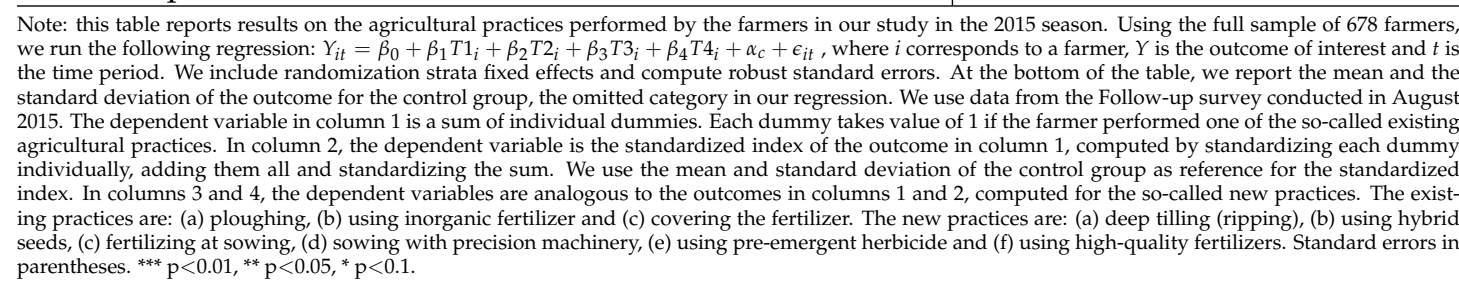 } \\
\hline
\end{tabular}




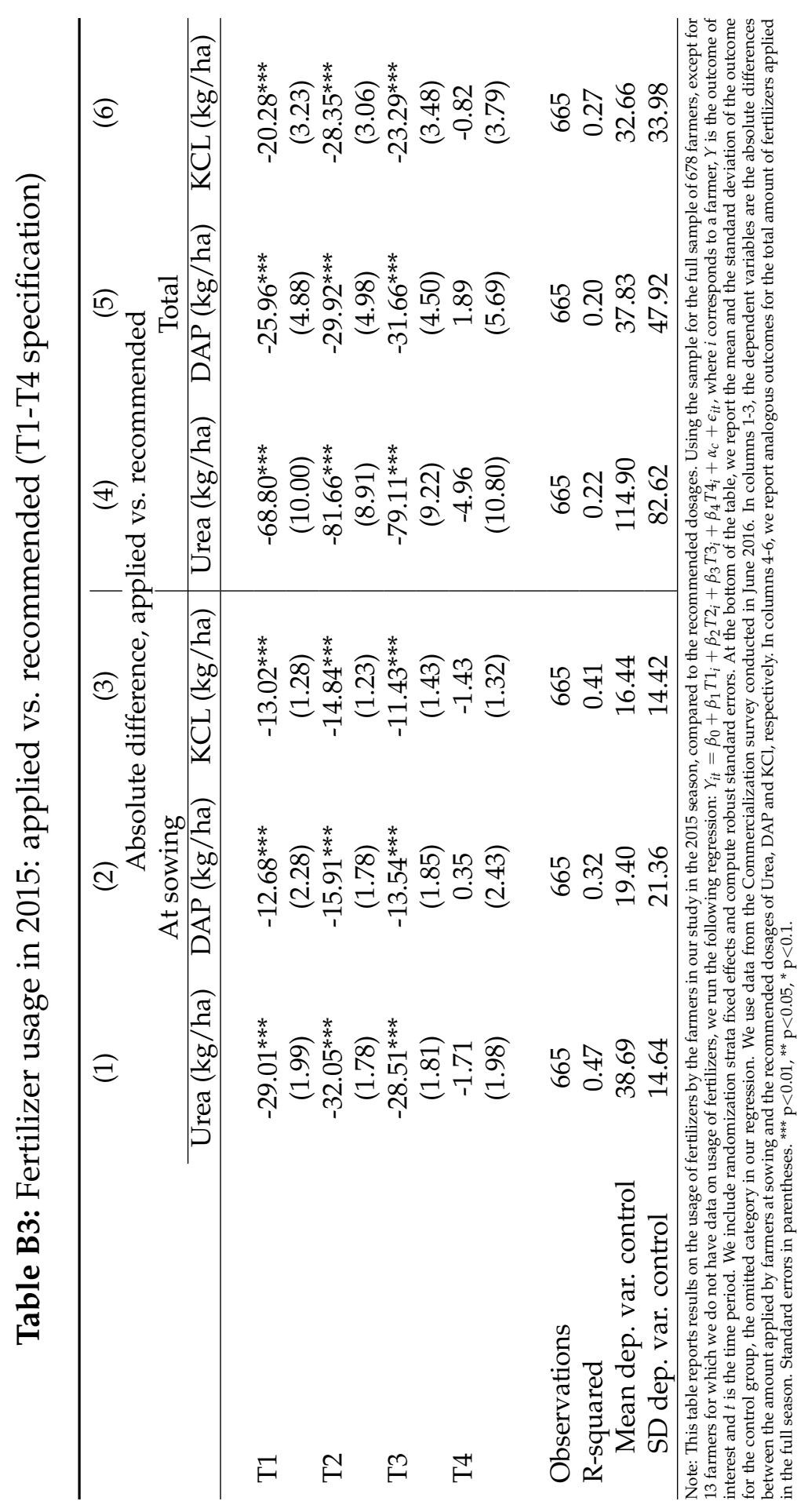


Table B4: Yields and profits 2015 (T1-T4 specification)

\begin{tabular}{|c|c|c|c|c|c|}
\hline & $\begin{array}{c}(1) \\
\text { Self-reported } \\
\text { yields (t/ha) }\end{array}$ & $\begin{array}{c}\text { (2) } \\
\text { Revenue } \\
\text { (Mex\$/ha) }\end{array}$ & $\begin{array}{c}(3) \\
\text { Costs } \\
(\mathrm{Mex} \$ / \mathrm{ha})\end{array}$ & $\begin{array}{c}(4) \\
\text { Profits } \\
\text { (Mex\$/ha) }\end{array}$ & $\begin{array}{c}(5) \\
\text { Profits (no subsidy) } \\
\text { (Mex\$/ha) }\end{array}$ \\
\hline $\mathrm{T} 1$ & $\begin{array}{l}0.40^{* *} \\
(0.18)\end{array}$ & $\begin{array}{c}1406.68^{* *} \\
(592.60)\end{array}$ & $\begin{array}{c}864.78^{* * * *} \\
(238.88)\end{array}$ & $\begin{array}{c}541.90 \\
(594.52)\end{array}$ & $\begin{array}{c}2339.56^{* * *} \\
(596.91)\end{array}$ \\
\hline $\mathrm{T} 2$ & $\begin{array}{l}0.28^{*} \\
(0.15)\end{array}$ & $\begin{array}{l}987.91^{*} \\
(518.58)\end{array}$ & $\begin{array}{l}669.80^{* *} \\
(239.15)\end{array}$ & $\begin{array}{c}318.10 \\
(520.82)\end{array}$ & $\begin{array}{c}2303.56^{* * *} \\
(522.72)\end{array}$ \\
\hline T3 & $\begin{array}{l}0.36^{* *} \\
(0.16)\end{array}$ & $\begin{array}{c}1283.45^{* *} \\
(527.25)\end{array}$ & $\begin{array}{c}1022.94^{* * *} \\
(261.33)\end{array}$ & $\begin{array}{c}260.51 \\
(505.60)\end{array}$ & $\begin{array}{c}2260.01^{* * *} \\
(513.86)\end{array}$ \\
\hline $\mathrm{T} 4$ & $\begin{array}{c}0.21 \\
(0.16)\end{array}$ & $\begin{array}{c}656.03 \\
(543.49)\end{array}$ & $\begin{array}{c}46.55 \\
(273.37)\end{array}$ & $\begin{array}{c}609.48 \\
(529.58)\end{array}$ & $\begin{array}{c}763.60 \\
(531.50)\end{array}$ \\
\hline Observations & 678 & 678 & 678 & 678 & 678 \\
\hline R-squared & 0.25 & 0.28 & 0.22 & 0.21 & 0.23 \\
\hline Mean dep. var. control & 2.36 & 7919.22 & 5280.02 & 2639.20 & 2718.87 \\
\hline SD dep. var. control & 1.33 & 4397.72 & 2351.52 & 4024.33 & 4024.42 \\
\hline \multicolumn{6}{|c|}{ 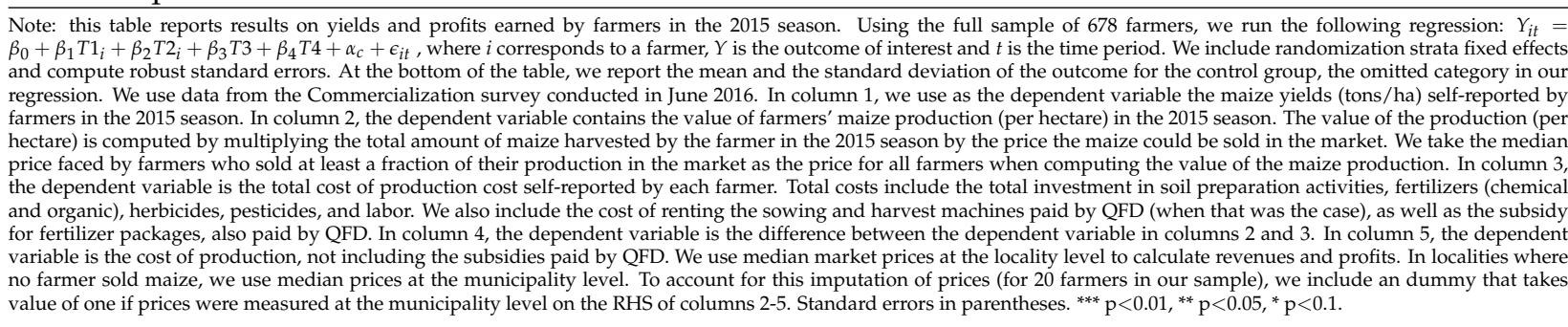 } \\
\hline
\end{tabular}

Table B5: Practices 2017 (T1-T4 specification)

\begin{tabular}{|c|c|c|c|c|}
\hline & \multirow{2}{*}{\multicolumn{2}{|c|}{$\begin{array}{cc}(1) & (2) \\
\text { Existing practices } 2017\end{array}$}} & \multirow{2}{*}{\multicolumn{2}{|c|}{$\begin{array}{c}(3) \\
\text { All new practices } 2017\end{array}$}} \\
\hline & & & & \\
\hline & $\begin{array}{l}\text { Total practices } \\
\text { applied }\end{array}$ & $\begin{array}{l}\text { Standardized } \\
\text { Index }\end{array}$ & $\begin{array}{l}\text { Total practices } \\
\text { applied }\end{array}$ & $\begin{array}{l}\text { Standardized } \\
\text { Index }\end{array}$ \\
\hline \multirow[t]{2}{*}{$\mathrm{T} 1$} & 0.04 & 0.05 & $0.46^{* * *}$ & $0.63^{* * *}$ \\
\hline & $(0.11)$ & $(0.13)$ & $(0.12)$ & $(0.17)$ \\
\hline \multirow[t]{2}{*}{$\mathrm{T} 2$} & -0.10 & -0.08 & $0.33^{* *}$ & $0.53^{* * *}$ \\
\hline & $(0.11)$ & $(0.12)$ & $(0.11)$ & $(0.16)$ \\
\hline \multirow[t]{2}{*}{ T3 } & -0.06 & -0.04 & $0.78^{* * *}$ & $1.08^{* * *}$ \\
\hline & $(0.10)$ & $(0.12)$ & $(0.12)$ & $(0.17)$ \\
\hline \multirow[t]{2}{*}{$\mathrm{T} 4$} & 0.10 & 0.11 & $0.24^{* *}$ & $0.39^{* *}$ \\
\hline & $(0.10)$ & $(0.12)$ & $(0.11)$ & $(0.16)$ \\
\hline Observations & 678 & 678 & 678 & 678 \\
\hline R-squared & 0.07 & 0.05 & 0.20 & 0.17 \\
\hline Mean dep. var. control & 2.31 & 0.00 & 0.42 & 0.00 \\
\hline SD dep. var. control & 0.89 & 1.00 & 0.79 & 1.00 \\
\hline
\end{tabular}

Note: this table reports results on the agricultural practices performed by the farmers in our study in the 2017 season. Using the full sample of 678 farmers, we run the following regression: $Y_{i t}=\beta_{0}+\beta_{1} T 1_{i}+\beta_{2} T 2_{i}+\beta_{3} T 3_{i}+\beta_{4} T 4_{i}+\alpha_{c}+\epsilon_{i t}$, where $i$ corresponds to a farmer, $Y$ is the outcome of interest and $t$ is the time period. We include randomization strata fixed effects and compute robust standard errors. At the bottom of the table, we report the mean and the standard deviation of the outcome for the control group, the omitted category in our regression. We use data from the Final survey conducted in May 2017. The dependent variable in column 1 is a sum of individual dummies. Each dummy takes value of 1 if the farmer performed one of the so-called existing agricultural practices. In column 2, the dependent variable is the standardized index of the outcome in column 1, computed by standardizing each dummy indicultural practices. In column 2, the dependent variable is the standardized index of the outcome in column 1, computed by standardizing each dummy indi-
vidually, adding them all and standardizing the sum. We use the mean and standard deviation of the control group as reference for the standardized index. In columns 3 and 4 , the dependent variables are analogous to the outcomes in columns 1 and 2, computed for the so-called new practices. The existing practices are: (a) ploughing, (b) using inorganic fertilizer and (c) covering the fertilizer. The new practices are: (a) deep tilling (ripping), (b) using hybrid seeds, (c) fertilizing at sowing, (d) sowing with precision machinery, (e) using pre-emergent herbicide and (f) using high-quality fertilizers. Standard errors in parentheses. ${ }^{* * *} \mathrm{p}<0.01,{ }^{* *} \mathrm{p}<0.05,{ }^{*} \mathrm{p}<0.1$ 


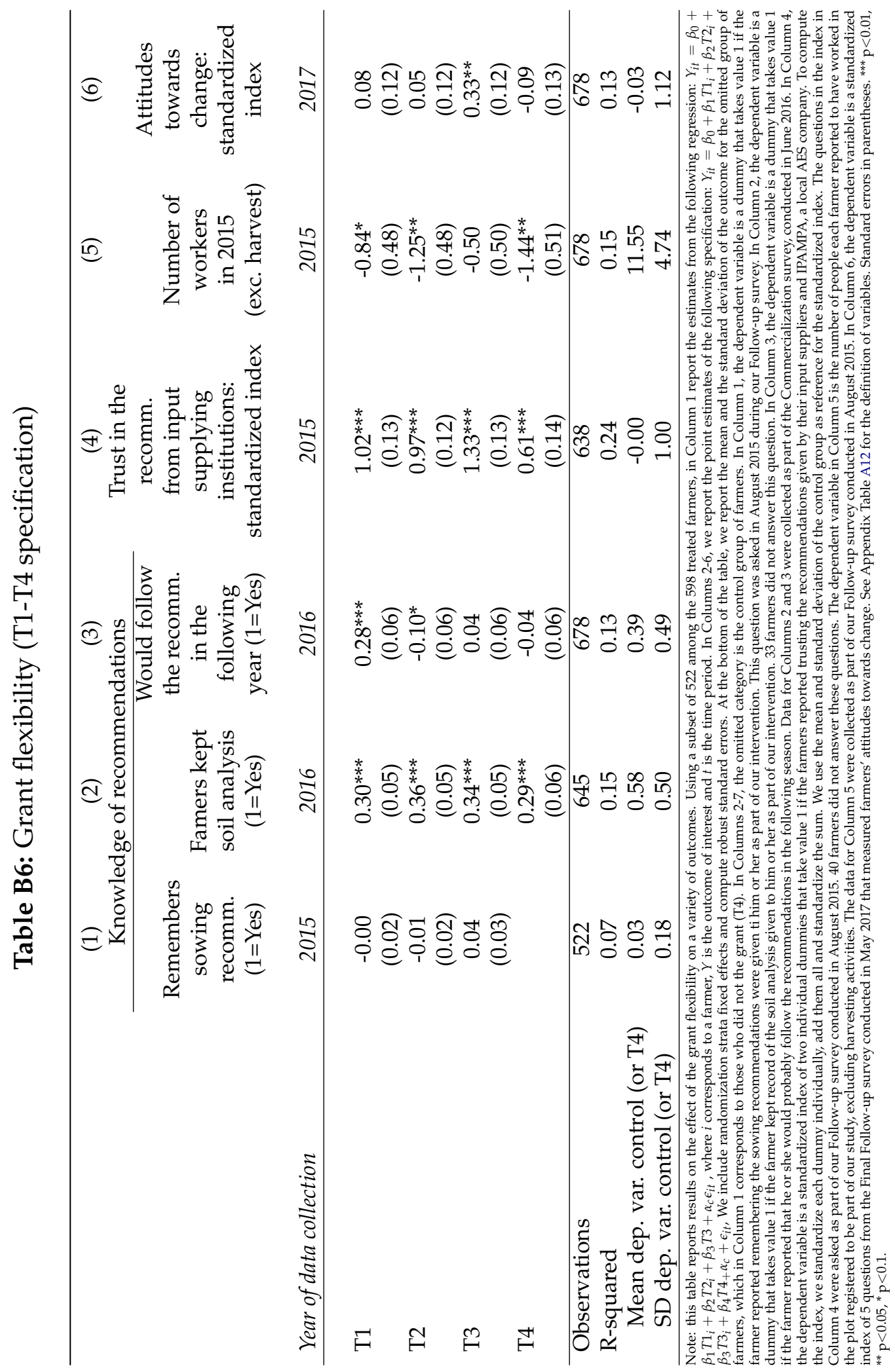


Table B7: WTP for fertilizers (T1-T4 specification)






\section{Treatment Effect Heterogeneity}

In this section, we examine whether treatment effects in fertilizer use varied by the baseline gap between fertilizer use in 2014 and the recommendations based on the soil analyses. In particular, we explore whether farmers with a larger gap at baseline were more responsive to the treatments.

Table B8 reports the results. We focus on Urea as the results for DAP are qualitatively similar and discuss the results for $\mathrm{KCl}$ below. First, the point-estimates for the main effect are all negative for $\mathrm{T} 1-\mathrm{T} 3$ (though the effect for $\mathrm{T} 1$ is not statistically distinguishable from zero, all relative to the control arm). Second, the interaction effects for all three arms are significantly negative - at the mean gap level of $100 \mathrm{~kg} /$ ha of Urea in 2014, they imply a reduction in the gap by around 40 to $20 \mathrm{~kg} / \mathrm{ha}$ (or equivalently, each additional one $\mathrm{kg} / \mathrm{ha}$ gap in 2014 corresponds to a reduction in usage of 0.2 to $0.4 \mathrm{~kg} / \mathrm{ha}$ ). Further, the interaction effects for all arms T1 $-\mathrm{T} 4$ are not statistically distinguishable suggesting that the effect of the 2014 gap on 2015 usage did not vary by arm.

The most interesting aspect of the heterogeneity appears to be in $T 4$ that did not receive a grant. Contrary to the coefficients on the $T 1-T 3$ dummies that are all negative, the coefficient on the T4 dummy is actually positive and is substantially different from zero. This implies that for low enough values for the 2014 gap, the estimated ITT for T4 differs in sign for the estimated ITT for T2 (or T3). In particular, this suggests that the recommendations in $T 4$ were less effective for farmers who had small pre-intervention gaps (relative to $T 2$ farmers with the same gap). In fact, the estimated ITT is positive for T4 at low levels of the 2014 fertilizer gap but entirely negative for $T 2$ regardless of the 2014 fertilizer gap. The difference in the signs of the ITT across the distribution of the 2014 fertilizer gap is enough to explain the overall zero effect we find for T4 in the main regression specification - positive treatment effects at the lower ranges of the distribution offset the negative effects at the higher ranges of the distribution. This suggests that farmers in T4 who were over-using urea in 2014 by a lot were likely to reduce usage but this was not true for those who were usage gaps were smaller. 







\title{
Online Appendix for Autonomy and Specificity in Agricultural Technology Adoption: Evidence from Mexico
}

\author{
by Carolina Corral, Xavier Giné, Aprajit Mahajan, and Enrique Seira \\ FOR ONLINE PUBLICATION
}

\section{Online Appendix A Soil Analysis and Recommendations}

Soil samples were collected from the designated sub-plot during February and March 2015. Surveyors divided up the sub-plot into (up to) 6 relatively homogenous regions and took 15 soil samples (from a depth of $30 \mathrm{~cm}$ ). These 15 samples were then mixed and collected in bags following standard soil analysis protocols. These bags were then sent to Fertilab for analysis. ${ }^{50}$ Based on focus group discussions conducted in December 2014 we developed a template for reporting the soil analysis and recommendations divided into three parts:

\section{OA A.1 Soil Analysis}

The soil analysis provided the main soil characteristics in a relatively easy to read format for farmers. The soil analysis measured a range of factors that measured the soil texture (percentage of sand, silt and clay) its ability of retain and transfer nutrients ( $\mathrm{pH}$ levels, sand and lime concentrations, saturation points and cationic exchange capacity) as well as the levels of 13 key nutrients - the primary macro-nutrients $(\mathrm{N}, \mathrm{P}, \mathrm{K})$, the secondary macro-nutrients $(\mathrm{Ca}, \mathrm{Mg}, \mathrm{S})$ and selected micronutrients $(\mathrm{Na}, \mathrm{Fe}, \mathrm{Zn}, \mathrm{Mn}, \mathrm{Cu}, \mathrm{B}, \mathrm{Al})$ - and the level of organic matter in the soil.

Nitrogen $(\mathrm{N})$ affects plant growth. Many spoil microorganisms found in the soil are able to convert organic $\mathrm{N}$ found in plant residue, soil organic matter, or bacteria into inorganic $\mathrm{N}$ forms that can be taken up by plans. plant available inorganic Ammonium $\left(\mathrm{NH}_{4}^{+}\right)$and nitrate $\left(\mathrm{NO}_{3}^{-}\right)$ are such forms of mineral or inorganic $\mathrm{N}$. Nitrate $\mathrm{NO}_{3}^{-}$is water soluble and does not remain in the soil.

Phosphorous $(\mathrm{P})$ is critical in root development, crop maturity and seed production. P deficiency is a common problem causing crop stunting or discoloration in the field. One of the major contributing sources of $\mathrm{P}$ for crops comes from soil organic matter.

\footnotetext{
${ }^{50}$ Fertilab is one of the best known laboratories in Mexico and is accredited by the North American Proficiency Testing Program (run by the Soil Sciences Society of America) that certifies laboratory operations in the United States and elsewhere.
} 
Potassium (K) is required for the activation of enzymes throughout. It is critical for the crop's ability to withstand extreme cold and hot temperatures, drought and pests. Potassium increases water use efficiency and transforms sugars to starch in the grain-filling process.

Calcium $(\mathrm{Ca})$, magnesium $(\mathrm{Mg})$, and sulfur $(\mathrm{S})$, are considered secondary macronutrients, because they are required in amounts smaller than those typically needed for $\mathrm{N}, \mathrm{P}$, or K. These elements, however, are equally important for plant growth and nutrition.

Micronutrients are essential nutrients for plant growth that are used in relatively small amounts by crops. Boron (B), zinc ( $\mathrm{Zn})$, manganese $(\mathrm{Mn})$, iron $(\mathrm{Fe})$ and copper $(\mathrm{Cu})$ will only make up a small proportion of a plant; however, a deficiency in any of these elements has the potential to cause a decrease in crop quality or yield.

\section{OA A.2 Stability of soil characteristics}

In February, 2017 we visited a randomly chosen set of 99 control plots and re-did the soil analysis to measure the stability of the nutrient content in the soil. Table OA1 in this online appendix shows that there are large and precise correlations across years, particularly for macronutrient, so that the information from the 2015 soil analysis remained relevant in 2017.51

\section{Online Appendix B Soil Analysis and Recommendations}

Figures OA2-OA6 provide a sample of the report. The first page explained the program and required a signature from the farmer for consent. The second page provided basic information about the plot's physical characteristics (e.g. texture, saturation, organic matter, $\mathrm{pH}$ level and bulk density). It also provided the nutrient levels in the plot (e.g. N, P, K and secondary macronutrients and micronutrients) as well as the required levels of nutrients for a maize yield of $4.5 \mathrm{mt}$ / ha under normal weather conditions. The third page provided a "shopping list", that is, the list of recommended fertilizer amounts (DAP, urea, $\mathrm{KCl}$ and micronutrients) and its cost at our partner agro-dealer. Costs were divided into the portion paid by the research team and the remainder which the farmer was expected to provide. The fourth and fifth pages compared the farmer's own 2014 input use and costs (from the baseline survey) to the recommended input mix and costs. They also provided sub-plot yields and prices from 2014. These 2014 costs and revenues were compared with the expected yields, revenues (using 2014 prices) and costs of inputs if the recommendations were followed and Fertilab's assumptions (about weather and temperature) proved accurate - the research teams were careful to explain the assumptions underlying the yield predictions.

\footnotetext{
${ }^{51}$ Due to this persistence in the characteristics of the soil content, the USDA recommends that soil tests be carried out every 3-5 years (see e.g. https://perma.cc/E8GN-GWGM).
} 
Table OA1: Soil Analysis comparison 2017 vs. 2015

\begin{tabular}{|c|c|c|c|}
\hline \multicolumn{4}{|c|}{$Y_{2017}=\alpha+\beta Y_{2015}+\epsilon$} \\
\hline Soil characteristic & $\alpha$ & $\beta$ & $R^{2}$ \\
\hline \multirow[t]{2}{*}{$\mathrm{pH}$} & $2.71^{* * *}$ & $0.63^{* * *}$ & 0.51 \\
\hline & 0.41 & 0.07 & \\
\hline \multirow[t]{2}{*}{ Organic Matter (OM) } & 0.10 & $0.89^{* * *}$ & 0.60 \\
\hline & 0.06 & 0.08 & \\
\hline \multirow[t]{2}{*}{ Nitrogen $(\mathrm{N})$} & $3.49^{* *}$ & $0.31^{* *}$ & 0.22 \\
\hline & 1.59 & 0.12 & \\
\hline \multirow[t]{2}{*}{ Phosphorus (P) } & $6.84^{* * *}$ & $0.70^{* * *}$ & 0.82 \\
\hline & 1.48 & 0.04 & \\
\hline \multirow[t]{2}{*}{ Potassium (K) } & $64.99^{* *}$ & $0.76^{* * *}$ & 0.52 \\
\hline & 30.15 & 0.19 & \\
\hline \multirow[t]{2}{*}{ Calcium (Ca) } & $1,447.66^{* * *}$ & 0.10 & 0.01 \\
\hline & 155.75 & 0.09 & \\
\hline \multirow[t]{2}{*}{ Magnesium (Mg) } & $37.84^{* *}$ & $0.97^{* * *}$ & 0.36 \\
\hline & 17.65 & 0.13 & \\
\hline \multirow[t]{2}{*}{ Sodium (Na) } & $8.90^{* * *}$ & $0.44^{* * *}$ & 0.27 \\
\hline & 1.94 & 0.12 & \\
\hline \multirow{2}{*}{ Iron $(\mathrm{Fe})$} & $7.27^{* * *}$ & $0.52^{* * *}$ & 0.64 \\
\hline & 1.39 & 0.05 & \\
\hline \multirow[t]{2}{*}{ Zinc $(\mathrm{Zn})$} & 0.10 & $0.64^{* * *}$ & 0.90 \\
\hline & 0.06 & 0.11 & \\
\hline \multirow[t]{2}{*}{ Manganese (Mn) } & $3.09^{* *}$ & $0.26^{* * *}$ & 0.18 \\
\hline & 1.13 & 0.07 & \\
\hline \multirow[t]{2}{*}{ Copper $(\mathrm{Cu})$} & $0.17^{* * *}$ & $0.62^{* * *}$ & 0.93 \\
\hline & 0.02 & 0.01 & \\
\hline \multirow[t]{2}{*}{ Boron (B) } & $1.06^{* * *}$ & $0.19^{* *}$ & 0.09 \\
\hline & 0.01 & 0.07 & \\
\hline
\end{tabular}

do-file: APPENDIX_SA_2015vs2017.do. Datasets: Soil analysis (2015 and 2017).

$\mathrm{OA}-3$ 


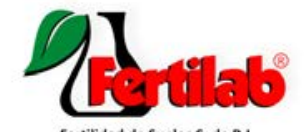

Análisis que Rinden Frutos

Fertilidad de Suelos $S$, de $R$.

\section{DIAGNOSTICO DE LA FERTILIDAD DEL SUELO}

\begin{tabular}{|llll|}
\hline & & \multicolumn{3}{c|}{ INFORMACIÓN GENERAL } \\
\hline Cliente & Ismael Zacamolpa Cerbani & Cultivo Anterior & Ninguno \\
No. de Registro & SU-35440 & Cultivo a Establecer & Maiz \\
Fecha de Recepción & $09 / 03 / 2015$ & Tipo de Abono Organico & N/A \\
Fecha de Entrega & $11 / 03 / 2015$ & Tipo de Agricultura & Temporal \\
Rancho o Empresa & Cuaxomulco & Manejo de Residuos & Retirados \\
Municipio & Cuaxomulco & Meta de Rendimiento & 5 Ton/Ha Ton/Ha \\
Estado & Tlaxcala & Prof. Muestra & $0-30 \mathrm{~cm}$ \\
Identificación & .23 .01 .10 .01 & &
\end{tabular}

\begin{tabular}{llll} 
Identificación & 23.01.10.01 & Prof. Muestra & $0-30 \mathrm{~cm}$ \\
\hline
\end{tabular}

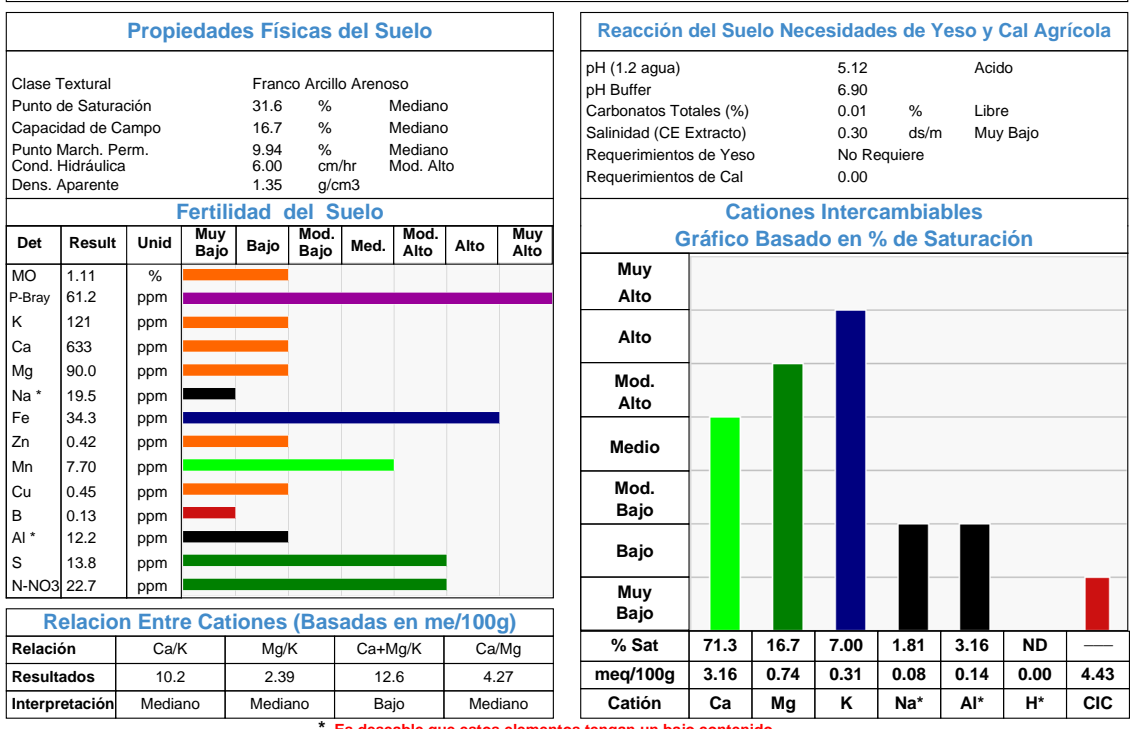

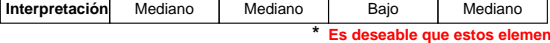

engan un bajo contenido

Interpretación Resumida del Diagnostico de la Fertilidad del Suelo

Suelo con $\mathrm{pH}$ acido. Suelo de textura media. Libre de carbonatos. Libre de sales. Bajo nivel de materia organica, es recomendable su aportacion. Bajo nivel de calcio. Muy alto suministro de fosforo disponible.Contenido bajo de potasio. Bajo nivel de magnesio. Suministro

En cuanto a la disponibilidad de micronutrientes: Pobre en zinc. Bajo contenido de cobre. Muy pobre en boro.

Poniente 6. No. 200 Ciudad industrial

Celaya, Gto. C.P. 38010

Tel. (461) 6145238,6147951

www.fertilab.com.mx
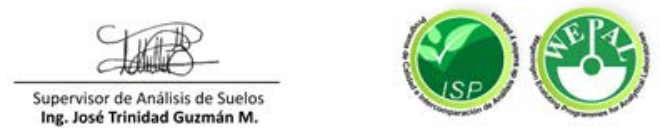

Figure OA1: Fertilab Original Soil Analysis 
Estimado/a Señor/a [NAME OF THE FARMER], de [NAME OF THE LOCALITY]

La Asociación Civil Qué Funciona para el Desarrollo (QFD) le informa de que usted ha salido beneficiado con el siguiente apoyo para utilizar en la hectárea delimitada en su parcela [NAME OF THE PLOT]

- Vale de \$1200 pesos para la compra de fertilizante formulado de acuerdo al estado nutricional de su parcela y requerimientos de su cultivo

- Ayuda para la renta de maquinaria de precisión para fertilizar a la siembra por valor $\$ 800$ pesos

- Asistencia técnica por parte de un ingeniero agrónomo

El día [date] a las [time] en [place] tendrá lugar la reunión en la que:

- Usted conocerá al ingeniero agrónomo que le dará asistencia técnica: ING. [NAME OF THE ENGINEER] cuyo número de teléfono es [PHONE NUMBER]. Si no puede acudir a la reunión por favor póngase en contacto con él/ella para re-agendar.

- Se le entregará el vale por valor de \$1,200 pesos

- Se le indicará la fecha en la que usted tiene que recoger su paquete de fertilización en la dirección indicada más abajo

- Se le explicará cómo funciona la maquinaria de precisión y cómo se calibra la maquinaria

- Se le indicará cuál será su fecha de siembra en la hectárea delimitada usando la maquinaria de precisión

La dirección a la que tiene usted que pasar a recoger su fertilizante es: [ADDRESS] (VER MAPA IMPRESO EN EL REVERSO DE ESTA HOJA) RECUERDE: Tiene que presentar su vale y su IFE para que puedan entregarle sus paquetes.

Además, es MUY IMPORTANTE que usted:

a. Siembre en la fecha que ingeniero agrónomo le indique ya que iremos con maquinaria para que le ayude a sembrar mejor. RECUERDE: Las recomendaciones que le hicimos no son válidas si no se siembra con maquinaria de precisión.

b. Use los fertilizantes adquiridos con nuestro vale únicamente en la hectárea delimitada por nuestro equipo.

Si tiene usted dudas no dude en contactarnos en nuestras oficinas del centro de Tlaxcala:

\section{[CONTACT INFORMATION]}

Conforme usted entiende y acepta lo expuesto en la presente carta le pedimos que la firme en el lugar indicado.

Atte el equipo de Qué Funciona para el Desarrollo A. C.

Firma del productor Nombre

Firma ingeniero QFD Nombre Fecha Fecha

Figure OA2: Recommendation letters (page 1) 
ID. .23.01.09.

\section{RECOMENDACIÓN PARA FEDERICO SERRANO HERNANDEZ \\ CUAXOMULCO, CUAXOMULCO}

\begin{tabular}{|l|l|}
\hline Municipio: & CUAXOMULCO \\
\hline Localidad: & CUAXOMULCO \\
\hline Parcela: & CUAXILCA \\
\hline Análisis de suelo: & 35455 \\
\hline
\end{tabular}

\section{Diagnóstico de sU PARCELA CUAXILCA}

El laboratorio Fertilab, especialista en suelos analizó la muestra de su parcela y encontró que existen los siguientes niveles de nutrientes:

\begin{tabular}{|lllll|}
\hline \multicolumn{2}{c}{ Propiedades Físicas del Suelo } & \multicolumn{2}{c|}{ Reacción del Suelo } \\
\hline Clase Textural: & Franco Arcillo Arenoso & $\mathrm{pH}(1: 2$ agua): & 6,69 & Neutro \\
\hline Densidad Aparente & $1,1 \mathrm{~g} / \mathrm{cm} 3$ & Materia Orgánica: & 0,56 \\
\hline Punto de Saturación: & $30 \%$ & Carbonatos Totales & $0,01 \%$ \\
\hline Cond. Hidráulica: & $6,7 \mathrm{~cm} / \mathrm{hr}$ & & \\
\hline
\end{tabular}

\begin{tabular}{|c|c|c|c|}
\hline Elementos en el suelo & Ideal para 4.5ton/ha & $\begin{array}{l}\text { Cantidad en su } \\
\text { parcela (ppm) }\end{array}$ & \\
\hline Nitrógeno & 71 & 5,44 & $x$ \\
\hline Fósforo & 30 & 4,86 & $x$ \\
\hline Potasio & 300 & 246 & $x$ \\
\hline Magnesio & 200 & 423 & $\checkmark$ \\
\hline Hierro & 9 & 10,2 & $\checkmark$ \\
\hline Zinc & 1.2 & 0,46 & $x$ \\
\hline Manganeso & 4 & 10,2 & $\checkmark$ \\
\hline Cobre & .5 & 0,99 & $\checkmark$ \\
\hline Boro & .8 & 0,02 & $x$ \\
\hline
\end{tabular}

ppm = partes por millón

Figure OA3: Recommendation letters (page 2)

OA - 6 


\section{HOJA DE PEDIDO}

Dado que le vamos a subsidiar con $\$ 1200$ pesos para la compra de fertilizantes para la siembra usted sólo tendrá que pagar la diferencia en caso de que el paquete de fertilización sea más costoso de $\$ 1200$ pesos. Si su paquete fuese más barato de $\$ 1200$ pesos usaremos la diferencia del dinero para pagar parte de su paquete para fertilizar a los 30-35 días (primera fertilización) hasta completar los 1200 pesos entre los dos paquetes.

¿Renta de maquinaria para la siembra? $\square$ Sí $\square$ NO

PAQUETE SIEMBRA

\begin{tabular}{|c|c|c|c|c|c|}
\hline & Dosis de fertilizar & tes en $\mathrm{kg} / \mathrm{ha}$ & & & \\
\hline Fertilizante & Marca Producto & \begin{tabular}{|l|} 
Total \\
solicitado
\end{tabular} & Costo unitario & Costo total & $\begin{array}{l}\text { A pagar } \\
\text { por QFD }\end{array}$ \\
\hline Sembradora de precisión & YARA & $x$ & $\mathrm{X}$ pesos & $\mathbf{x}$ & $\mathbf{x}$ \\
\hline Urea (Blanco) & YARA & $x$ & $\mathrm{X}$ pesos & $\mathbf{x}$ & $\mathbf{x}$ \\
\hline DAP (Negro) & YARA & $x$ & $\mathrm{X}$ pesos & $\mathbf{x}$ & $\mathbf{x}$ \\
\hline Cloruro de Potasio (Rojo) & YARA & $x$ & $\mathrm{X}$ pesos & $\mathbf{x}$ & $\mathbf{x}$ \\
\hline Microelementos & AGROQUÍMICA & $x$ & $\mathrm{X}$ pesos & $\mathbf{x}$ & $\mathbf{x}$ \\
\hline \multicolumn{3}{|c|}{ Gastos total en fertilizantes por hectárea (aproximado) } & $\mathrm{X}$ pesos & & \\
\hline \multicolumn{3}{|c|}{$\begin{array}{l}\text { Gastos total por hectárea Siembra (siembra aprox } \\
\text { SUMANDO LOS HERBIDAS SELLADORES Y } \\
\text { MAQUINARIA) }\end{array}$} & $X$ pesos & & \\
\hline
\end{tabular}

Remanente A LA SIEMBRA de los 2000 pesos: $\mathbf{X}$ pesos, si es negativo lo tienen que pagar el día que van a buscar el paquete SIEMBRA a YARA HUAMANTLA.

PAQUETE PRIMERA FERTILIZACIÓN DESPUÉS DE LA SIEMBRA (30-35 días)

\begin{tabular}{|l|c|c|c|c|c|}
\hline & \multicolumn{2}{|l}{ Dosis de fertilizantes en kg/ha } & \multicolumn{2}{l|}{} \\
\hline Fertilizante & Marca Producto & Total solicitado & $\begin{array}{c}\text { Costo unitario } \\
\text { (por kg) }\end{array}$ & Costo total & $\begin{array}{c}\text { A par por } \\
\text { QFD }\end{array}$ \\
\hline Urea (Blanco) & YARA & $X$ & $X$ pesos & X pesos & \\
\hline $\begin{array}{l}\text { Cloruro de Potasio } \\
\text { (Rojo) }\end{array}$ & YARA & $X$ & $X$ pesos & $X$ pesos & \\
\hline \multicolumn{2}{|l|}{ Gastos total en fertilizantes por hectárea (aproximado) } & $X$ pesos & & \\
\hline
\end{tabular}

Remanente a pagar por el productor A LA PRIMERA FERTILIZACIÓN X pesos, si es negativo lo tienen que pagar el día que van a buscar el paquete FERTILIZACIÓN 30 DÍAS a YARA HUAMANTLA.

Figure OA4: Recommendation letters (page 3) 


\section{Estimación de su Producción, Ingreso, y Costos del año pasado}

De acuerdo a los datos que nos dio hace unas semanas, hicimos las cuentas y estimamos que usted produjo aproximadamente $\mathbf{X}$ pesos en maíz por hectárea (con un precio de $\mathbf{X}$ pesos por tonelada), y tuvo un gasto aproximado de $\mathbf{X} \$ /$ ha en fertilizantes y otros insumos, por lo que le quedaron $\mathbf{X} \$ /$ ha después de pagar por todos los insumos que utilizó.

Valor de Producción por hectárea

\begin{tabular}{|l|l|}
\hline Producción 2014 & $X$ tn por ha \\
\hline Precio de Venta promedio & X\$ por tn \\
\hline Valor total de la producción $=4 \mathbf{x} \mathbf{2 7 6 2 , 4 5 \$}$ & $\mathbf{X} \$$ por ha \\
\hline
\end{tabular}

Costos de Producción por hectárea

\begin{tabular}{|l|l|}
\hline 1. Gastos en fertilizantes Químicos & X\$ por ha \\
\hline 2. Gastos en otros insumos y actividades & X\$ por ha \\
\hline Semillas & X\$ por ha \\
\hline Sembradora & X\$ por ha \\
\hline Costo de la producción (sin contar mano de obra) & X\$ por ha \\
\hline
\end{tabular}

Esta tabla contiene información sobre el dinero que gastó, así como las cantidades de cada uno de los fertilizantes que utilizó en ciclo P-V 2014.

\begin{tabular}{|c|c|c|c|c|c|}
\hline \multirow[b]{2}{*}{$\begin{array}{c}\text { Dosis de } \\
\text { fertilizantes en } \\
\text { kg/ha: }\end{array}$} & \multicolumn{4}{|c|}{ MOMENTO DE APLICACIÓN } & \multirow[b]{2}{*}{$\begin{array}{c}\text { Total } \\
\text { Kg aplicados por ha }\end{array}$} \\
\hline & $\begin{array}{c}\text { Siembra } \\
\text { Kg aplicados } \\
\text { por ha }\end{array}$ & $\begin{array}{c}\text { 1a } \\
\text { fertilización } \\
\text { Kg } \\
\text { aplicados } \\
\text { por ha } \\
\end{array}$ & $\begin{array}{c}\text { 2a } \\
\text { fertilización } \\
\mathrm{Kg} \\
\text { aplicados } \\
\text { por ha } \\
\end{array}$ & $\begin{array}{c}\text { 3a } \\
\text { fertilización } \\
\mathrm{Kg} \\
\text { aplicados } \\
\text { por ha } \\
\end{array}$ & \\
\hline Urea (Blanco) & $x$ & $x$ & $x$ & $x$ & $x$ \\
\hline DAP (Negro) & 150 & $x$ & $x$ & $x$ & $x$ \\
\hline Cloruro de Potasio & $x$ & $x$ & $x$ & $x$ & $x$ \\
\hline Sulfato de amonio & $x$ & $x$ & $x$ & $x$ & $x$ \\
\hline Microelementos & $x$ & $x$ & $x$ & $x$ & $x$ \\
\hline $\begin{array}{l}\text { Costo por } \\
\text { aplicación }\end{array}$ & $x$ & $x$ & $x$ & $x$ & $x$ \\
\hline
\end{tabular}

\footnotetext{
${ }^{1}$ Los costos totales fueron calculados en base a los precios que nos proporcionó cuando realizamos las muestras de análisis de suelo
}

Figure OA5: Recommendation letters (page 4) 


\section{Qipamparate}

ID. .XX.XX.XX.

\section{Paquete de fertilización con productividad mayor según los análisis de suelo de su parcela}

Según el análisis de suelo de su parcela, Ud. podría alcanzar una productividad de $\mathbf{4 . 5}$ toneladas en su parcela de prueba si en 2015 sigue los siguientes pasos:

1. Fertilizar a la siembra y a los 30 días después de la siembra con un paquete de fertilizantes diversificado.

2. Sembrar 20 kilogramos de semillas criollas o 60,000 de semillas híbridas por hectárea, utilizando una sembradora de precisión para asegurar que las semillas no compiten entre ellas por nutrientes, y que los fertilizantes no quemen sus semillas.

3. Aplicar un herbicida sellador a los 2 días de la siembra y volver a aplicar un herbicida a los 40 días de siembra para que sus plantas no compitan por nutrientes con malezas.

Le proponemos diversificar el uso de fertilizantes como se explica abajo para llegar a una productividad de hasta 4.5 toneladas por un costo total de $\mathbf{\$ X}$

\begin{tabular}{|l|c|c|c|}
\hline \multirow{2}{*}{$\begin{array}{c}\text { Dosis de fertilizantes } \\
\text { en kg/ha }\end{array}$} & \multicolumn{2}{|c|}{ MOMENTO DE APLICACIÓN } & \\
\cline { 2 - 4 } & $\begin{array}{c}\text { Siembra } \\
\text { Kg aplicados por ha }\end{array}$ & $\begin{array}{c}\text { 1era fertilización } \\
\text { Kg aplicados por ha }\end{array}$ & Kg totales \\
\hline Urea (Blanco) & $\mathrm{X}$ & $\mathrm{X}$ & $\mathrm{X}$ \\
\hline DAP (Negro) & $\mathrm{X}$ & $\mathrm{X}$ & $\mathrm{X}$ \\
\hline Cloruro de Potasio & $\mathrm{X}$ & $\mathrm{X}$ & $\mathrm{X}$ \\
\hline Minab R & $\mathrm{X}$ & $\mathrm{X}$ & $\mathrm{X}$ \\
\hline Costo por aplicación & $\mathbf{\$ X}$ & $\mathbf{\$ X}$ & $\mathbf{\$ X}$ \\
\hline
\end{tabular}

\begin{tabular}{|c|c|}
\hline PRODUCCION MAXIMA ESPERADA ${ }^{3}$ & 4.5 tn por ha \\
\hline Precio de Venta promedio & $\mathrm{X \$}$ por ton \\
\hline Valor de la producción & X\$ por ha \\
\hline 1. Gastos en fertilizantes & X\$ por ha \\
\hline 2. Gastos en otros insumos y actividades & $\mathrm{X} \$$ por ha** \\
\hline Semillas (20 kg por ha) & $0 \$$ por ha \\
\hline Sembradora & X \$ por ha \\
\hline Herbicida sellador (2 días después de la siembra) & X\$ por ha \\
\hline Herbicidas & X\$ por ha \\
\hline Costo de la producción & X\$ por ha \\
\hline
\end{tabular}

\footnotetext{
${ }^{2}$ Los precios son establecidos según la casa de fertilizantes YARA HUAMANTLA al 31/3 por kg de producto: Urea Yara: \$X, DAP Yara \$X, Cloruro de Potasio YARA: \$X; Agroquímica Minab-R \$X

${ }^{3}$ Las metas de producción están basadas en la calidad de su terreno son aproximadas y pueden variar dependiendo de factores externos como la cantidad de lluvia y la ocurrencia de eventos adversos como heladas o plagas. Los actividades agrícolas incluyen: sembradora de precisión (1200 pesos), 2 aplicaciones de herbicidas ( 400 pesos) y 5 jornales de mano de obra para herbicidas, fertilización y otras labores y cosecha (2000 pesos)
}

Figure OA6: Recommendation letters (page 5) 


\section{Online Appendix C Fertilizer Quality}

Appendix Table A5 presents the results from our fertilizer testing exercise. The label of a bag of urea (Panel A) shows an NPK content of $46-0-0$, so that $46 \%$ of the contents should be $\mathrm{N}$. According to the laboratory tests, the commonly used bag had a content of $46.7 \%$ while the YARA bag had a content of $47 \%$. Panel A also reports the total cost per bag which allows us to compute the cost per kilogram of nutrient at 13 pesos for the government subsidized bag compared to 13.6 pesos per $\mathrm{kg}$ of $\mathrm{N}$ in the YARA bag. We conclude that both urea bags have similar content and price per unit of nutrient. The results are similar for $\mathrm{KCl}$ (Panel C) although both bags have lower content of $\mathrm{K}$ than advertised. The YARA bag is a bit more expensive and thus its cost per $\mathrm{kg}$ of $\mathrm{K}$ is slightly higher. In Panel B however, we see that the subsidized DAP bag has much lower content of $\mathrm{N}$ and $\mathrm{P}$ than advertised. The label for DAP is 18-46-0, indicating that there should be $18 \% \mathrm{~N}$ and $46 \%$ P. According to the laboratory test, however, the government bag only had $10.4 \%$ of $\mathrm{N}$ and $14 \%$ of P. In contrast, the YARA bag had $16.7 \%$ of $\mathrm{N}$ and $36.2 \%$ of P. Therefore, even though the YARA bag was more expensive, its cost per $\mathrm{kg}$ of nutrient was in fact lower. We conclude that the YARA bag of DAP was of higher quality than the government subsidized one (and was in fact cheaper after adjusting for quality). 


\section{Online Appendix D Yield measurement protocol}

The harvesting and weighing of yields followed different protocols depending on whether farmers had already harvested the crop by the time of the team visit or whether the harvester/thresher could reach the program plot.

\section{OA D.1 Harvest by QFD}

For the 376 farmers that had not yet harvested the crop and with a program plot that could be reached by the mechanized harvester/thresher, the size of the plot was verified with the pre-registered GPS coordinates and the maize production on the registered plot was harvested and threshed. The grain was then collected and loaded onto a truck and weighed in the nearest weighing station.

\section{OA D.2 Harvest by farmer}

For the remaining farmers that had harvested by the time the team visited the registered plot or for those farmers that had not yet harvested but whose plot could not be reached by the harvester/thresher, the following procedure was used during the QFD team visit (the QFD comprised of an agronomist, a supervisor and 2 field assistants).

If the harvested cobs were in the field, all the cobs were packed in burlap sacks provided by QFD. Each sack was sealed and stitched with raffia ribbon provided by QFD and properly identified with a label including the producer's ID, the plot's name, locality and number of harvested sack. Once all the cobs were collected, the producer moved the bags to their q home, where they were placed in a ventilated and moisture-free room for drying.

If the harvested cobs were already at the farmer's home, the QFD supervisor had to verify that the cobs from the registered plot could be identified. This was the case when the cobs were stored in a separate location from other maize production or the program plot had produced maize that could be distinguished due to color or maize variety (hybrid or creole). If identification was not possible, then the team was instructed not to proceed with the yield measurement protocol (and for these farmers we only have self-reported yields).

A day before the shelling of maize, a QFD team visited the farmer to verify that moisture content (ideally less than $16 \%$ ) for the shelling. ${ }^{52}$ The team also verified that all the bags were still sealed and unaltered. For the shelling visit, the team arrived with a freight truck to transport the grain to the weighing station after shelling.

\footnotetext{
${ }^{52}$ To test moisture, five cobs from different parts of a burlap were collected and a few grains from each cob were collected at random. Grain moisture was then measured with a portable grain moisture tester MT- 16.
} 
The shelling was done with a mechanical sheller in an open space, placing a a blanket below the machine to avoid loss of grain, and placing a container to collect the grain and a sack to collect maize stalks. Cobs were fed slowly to the sheller and impurities of the threshed grain (such as maize stalk, leaves, etc) were removed. 